$$
\text { UNIVERSIDADE DE SÃO PAULO }
$$

FACULDADE DE FILOSOFIA, LETRAS E CIÊNCIAS HUMANAS DEPARTAMENTO DE LETRAS CLÁSSICAS E VERNÁCULAS PROGRAMA DE PÓS-GRADUAÇÃO EM LITERATURA PORTUGUESA

\author{
GABRIELA POTTI CERQUEIRA
}

MAR DE CONCRETO: UMA LEITURA DA CIDADE E DE SUA RELAÇÃO COM O MAR NOS POEMAS DE SOPHIA DE MELLO BREYNER ANDRESEN 


\author{
UNIVERSIDADE DE SÃO PAULO \\ FACULDADE DE FILOSOFIA, LETRAS E CIÊNCIAS HUMANAS \\ DEPARTAMENTO DE LETRAS CLÁSSICAS E VERNÁCULAS \\ PROGRAMA DE PÓS-GRADUAÇÃO EM LITERATURA PORTUGUESA
}

GABRIELA POTTI CERQUEIRA

MAR DE CONCRETO: UMA LEITURA DA CIDADE E DE SUA RELAÇÃO COM O MAR NOS POEMAS DE SOPHIA DE MELLO BREYNER ANDRESEN.

Dissertação apresentada ao Programa de Pós-Graduação em Literatura Portuguesa do Departamento de Letras Clássicas e Vernáculas da Faculdade de Filosofia, Letras e Ciências Humanas da Universidade de São Paulo para a obtenção do título de mestre em Literatura Portuguesa.

Área de concentração: Literatura Portuguesa

Orientadora: Profa. Dra. Annie Gisele Fernandes 
Autorizo a reprodução e divulgação total ou parcial deste trabalho, por qualquer meio convencional ou eletrônico, para fins de estudo e pesquisa, desde que citada a fonte.

Catalogação na Publicação

Serviço de Biblioteca e Documentação

Faculdade de Filosofia, Letras e Ciências Humanas da Universidade de São Paulo

Cerqueira, Gabriela Potti

Mar de concreto: uma leitura da cidade e de sua relação com o mar nos poemas de Sophia de Mello Breyner Andresen. / Gabriela Potti Cerqueira; orientadora Annie Gisele Fernandes. - São Paulo, 2011. $133 \mathrm{f}$

Dissertação (Mestrado) - Faculdade de Filosofia, Letras e Ciências Humanas da Universidade de São Paulo. Departamento de Letras Clássicas e Vernáculas. Área de concentração: Literatura Portuguesa.

1. Literatura portuguesa - crítica e interpretação. 2. Poesia. 3. Sujeito - poética. 4. Cidade. 5. Andresen, Sophia de Mello Breyner, 1919-2004. I. Título. II. Fernandes, Annie Gisele. 
Nome: CERQUEIRA, Gabriela Potti

Título: Mar de concreto: uma leitura da cidade e de sua relação com o mar nos poemas de Sophia de Mello Breyner Andresen.

Dissertação apresentada ao Programa de Pós-Graduação em Literatura Portuguesa do Departamento de Letras Clássicas e Vernáculas da Faculdade de Filosofia, Letras e Ciências Humanas da Universidade de São Paulo para a obtenção do título de mestre em Literatura Portuguesa.

Área de concentração: Literatura Portuguesa

Aprovada em:

Banca examinadora

Profa. Dra. Instituição:

Julgamento: Assinatura:

Profa. Dra. Instituição:

Julgamento: Assinatura:

Profa. Dra. Instituição:

Julgamento: Assinatura: 
Dedico este trabalho aos meus pais, Manoel e Valdelice, meu porto-seguro. Aos meus amados irmãos Carolina, Renata, Roberto e Lara Maria. E aos meus estimados amigos e irmãos de inspiração Patrícia Luna e Marcelo Catelan. 


\section{Agradecimentos}

A todos os professores que passaram pela minha vida e, de alguma forma, me inspiraram a amar a poesia, em especial,

à professora Sílvia, por me ensinar as primeiras letras;

à minha orientadora Profa. Dra. Annie Gisele Fernandes, sempre paciente e participante ao longo de todo o processo de realização deste trabalho. 


\section{Resumo}

CERQUEIRA, Gabriela Potti. Mar de concreto: uma leitura da cidade e de sua relação com o mar nos poemas de Sophia de Mello Breyner Andresen. 2011. 133 f. Dissertação (Mestrado) - Faculdade de Filosofia, Letras e Ciências Humanas, Universidade de São Paulo, São Paulo, 2011.

A cidade e sua relação com o mar nos poemas da autora portuguesa Sophia de Mello Breyner Andresen é o tema central do presente trabalho. Se, num primeiro momento, uma leitura superficial do espaço urbano em sua obra poética sugere uma perspectiva negativa, à medida que se dedica um olhar mais atento a essa poesia, é possível observar diferentes percepções do ambiente citadino. A análise pormenorizada apresentada no estudo em questão mostra que, nos poemas da autora, a visão da cidade que, tal qual Babilônia é corrupta e corruptora e se caracteriza como um espaço hostil bem como sombrio, coexiste com mais outros dois perfis de espaço urbano: as cidades délficas e as cidades sedutoras. Fazendo contraponto às herdeiras da Babilônia, as que compõem o primeiro grupo remetem à imagem da cidade que floresce do Apocalipse. Dotadas de elementos do espaço natural, elas são lugares nos quais o sujeito encontra claridade, pureza e acolhimento. Já o outro perfil de espaço urbano, composto pelas cidades sedutoras, é carregado de dualidade. Magnéticas, elas atraem o sujeito poético com suas luzes e brilhos, mas, ao mesmo tempo, também causam repulsa e emitem um esplendor falseado, num contexto em que aquilo que causa fascínio no sujeito coexiste com o que o desagrada e provoca desconforto. Entretanto, antes de apresentar essa análise do espaço citadino, o estudo traça um percurso que tem como ponto de partida uma característica constante na poesia da autora: a busca incisiva do real em todas as suas perspectivas, inclusive aquelas que sugerem uma relação antagônica. Partindo dessa abordagem mais panorâmica da obra de Sophia, o trabalho, num outro momento, evolui para a percepção do real de um ponto de vista mais restrito: o do espaço físico, dentro do qual o meio transformado pelo homem e 0 ambiente natural apresentam configurações distintas. Se florestas, desertos, rios e mares são lugares de liberdade, harmonia e identificação para o "eu", os muros, ruas e esquinas geralmente surgem como espaços de desajuste e isolamento. É da percepção que o sujeito poético revela ter desses ambientes que se chega ao eixo central apontado acima: as cidades e suas diferentes configurações. Exemplo mais marcante do meio transformado pelo homem, elas excedem a leitura associada à idéia de dor, confinamento e sofrimento. À medida que estabelecem diferentes relações, ora conflituosas, ora harmoniosas com elementos do meio natural - entre os quais o mar surge como principal expoente no contexto dessa poética -, elas revelam que existem outras leituras possíveis do espaço urbano.

Palavras-chave: Sophia de Mello Breyner Andresen, Cidade, Mar, Poesia portuguesa, Sujeito poético.

E-mail do autor (a): gabrielapotti@yahoo.com.br 


\section{Abstract}

CERQUEIRA, Gabriela Potti. Sea of concrete: a study of the city and its relation to the sea in Sophia de Mello Breyner Andresen's poems. 2011. 133 f. Dissertação (Mestrado) - Faculdade de Filosofia, Letras e Ciências Humanas, Universidade de São Paulo, São Paulo, 2011.

The city and its relation to the sea in Portuguese author Sophia de Mello Breyner Andresen's poems is the main theme of this study. If a superficial interpretation of the urban space in her poetry may suggest a negative perspective concerning the city, as the study progresses, different perceptions of the urban space emerge. The detailed analysis presented in this study shows that in the author's poems the conception of the city such as Babylon is corrupt and corrupting, spreads hostility and suffering coexists with two other types of cities: the delphic cities and the seductive cities. Contrasting with the successors of Babylon, the cities that belong to the first group refer to the ideal of the city described after the Apocalypse. Inhabited by elements from natural space, they are places where the self can find clarity, purity and hospitality. The other type of city, whose main characteristic is seduction, is conducted by dualism. Full of magnetism, they attract the self with their radiance and brightness, but, at the same time, their false splendor may seen repulsive in a context that the same thing that fascinates the self also bothers and causes discomfort. However, before presenting the analysis of the urban space, the study follows a way that begins with an essential characteristic in the author's poems: the search for all the perspectives of the real, including those that suggest antagonisms. Starting from a panoramic view of Sophia's poetry, the study is conducted to a more restrict perception of the real: the physic space, in which places transformed by the man and natural environment present contrasting configurations. If forests, deserts, rivers and seas are places that the self not only recognizes as essential for him but also seems to find the freedom and harmony he was looking for, the streets, corners and walls that surround him makes him feel displaced and lonely. The main theme of this study - the city - comes from the different conceptions of these places. One of the most representative examples of the environment transformed by man, the cities exceed the image of sorrow, suffering and isolation. As they build different relations (sometimes antagonistic, sometimes harmonious) with elements from a natural environment - in which the sea is presented as a main exponent in this poetry -, they reveal that other interpretation of the urban space can be found.

Keywords: Sophia de Mello Breyner Andresen, City, Sea, Portuguese poetry, the self. 


\section{Sumário}

1. Introdução . . . . . . . . . . . . . . . . . . . . . . .99

2. A poética de Sophia . . . . . . . . . . . . . . . . . . . 14

3. O espaço natural e a identidade do sujeito $\ldots \ldots \ldots \ldots \ldots \ldots$

4. Mar de concreto: uma leitura da cidade e de sua relação com o mar nos poemas de Sophia de Mello Breyner Andresen . . . . . . . . . . . . . . . 71

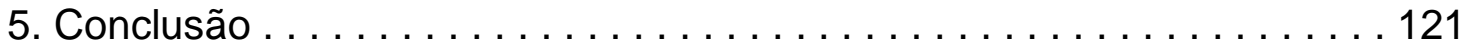

Referências bibliográficas . . . . . . . . . . . . . . . . . . . . . . . . . 126 


\section{Introdução}

O presente estudo apresenta uma leitura da cidade e sua relação com o mar nos poemas de Sophia de Mello Breyner Andresen. Num contexto em que, num primeiro momento, o elemento urbano é apresentado como espaço de dor e o marítimo, de felicidade, a proposta é investigar como essa relação é construída, quais as diferentes leituras que o espaço urbano suscita nessa poética, buscando identificar se existe uma unidade por trás das relações dualistas.

Para se chegar à análise do espaço citadino nos poemas da autora, o trabalho tem como ponto de partida uma característica constante que perpassa toda a sua criação: a busca incisiva do real em todos os seus ângulos, inclusive os antagônicos, conforme a própria poeta argumenta: "Aquele que vê o espantoso esplendor do mundo é logicamente levado a ver o espantoso sofrimento do mundo. Aquele que vê o fenômeno quer ver todo o fenômeno" (ANDRESEN, 2004, p.155).

Baseado na concepção da leitura do real em sua totalidade como uma marca incisiva dessa poesia, optou-se por iniciar o estudo com uma abordagem mais panorâmica da poesia da autora, contextualizando sua obra e identificando seus principais traços no capítulo que abre a discussão: "A poética de Sophia". Antes de chegar à análise da cidade propriamente dita, o capítulo seguinte - "O espaço natural e a identidade do sujeito" - traz uma abordagem dos diferentes espaços que permeiam sua obra, revelando a configuração que eles assumem no âmbito do meio natural (jardins, praias, rios e florestas) em contraponto com o ambiente moldado pelo homem (cidades, ruas e esquinas). De modo que esses dois capítulos que antecedem a discussão sobre o ambiente citadino abrem caminho para a análise do ambiente urbano, tema central do presente trabalho, discutido no capítulo "Mar de concreto: uma leitura da cidade e de sua relação com o mar nos poemas de Sophia Andresen".

Na maioria das vezes rivalizando com a cidade, um ambiente reaparece com frequência nos poemas da autora: o mar. Em sua obra, é recorrente a temática do espaço marítimo como meio natural de pureza, liberdade e beleza. Contrastando com essa perspectiva, a percepção da realidade modificada pelo 
homem surge com um viés negativo, como um mundo habitado pela corrupção e pela dor. Nesse contexto, vale chamar a atenção para a cidade como uma das formas mais freqüentes com que esse espaço de infelicidade é apresentado. Um exemplo da relação antagônica entre esses dois elementos está nos versos do poema "Cidade", publicado na obra de estreia de Sophia, Poesia (1944). Nesse texto, adjetivos negativos, como "sujo" e "hostil", contrapõem-se à limpidez do mar subentendida pela própria referência direta à nudez das praias:

\footnotetext{
Cidade, rumor e vaivém sem paz das ruas,

Ó vida suja, hostil, inutilmente, gasta,

Saber que existe o mar e existem praias nuas,

Montanhas sem nome e planícies mais vastas

Que o mais vasto desejo,

E eu estou em ti fechada e apenas vejo

Os muros e as paredes e não vejo

Nem o crescer do mar nem o mudar das luas.
}

O choque que remonta a dois universos distintos e antagônicos também aparece em "Tempo de não". Publicado em uma obra cujo título evoca a imagem da água, llhas (1989), e por extensão o mar, o poema apresenta, de um lado, esse elemento como um espaço mítico - "a praia lisa que sonhei" - e, de outro, a cidade, como um lugar no qual as tragédias abundam: "a cidade onde habito é rica em desastres".

No tocante a essa característica que permeia a obra da autora, é interessante considerar a opinião de pesquisadores e críticos sobre a relação entre esses dois espaços. Francisco de Sousa Tavares observa que o mundo do eu poético não é o dos homens, da cidade e sua agitação, imundice e agressividade, mas o do mar e da natureza, que surge como símbolo da vida (TAVARES, 2001, p.75-76).

Vivian Steinberg faz também menção à relação de oposição entre mar/praia e cidade, reforçando ainda mais o cenário propício para um estudo que dedique um olhar sobre a variável citadina versus a marítima dentro da tessitura poética de Sophia de Mello Breyner Andresen (STEINBERG, 2006, p. 9).

Outro autor que reitera o antagonismo latente entre esses dois espaços é Óscar Lopes, que toma como referência passagens de outros poemas. Em 
todas as menções do autor ao assunto é visível a perspectiva negativa da cidade, apresentada como um lugar que o eu lírico não reconhece como seu, em contraponto com o espaço marítimo, com o qual ele se identifica de imediato:

Espaço urbano, em oposição ao espaço natural, é invariavelmente representado como "cidade suja" ou "cidade alheia", reino da alienação e do mal: "Eu me perdi na sordidez do mundo / Eu me salvei na limpidez da terra / Eu me busquei no vento e me encontrei no mar, Lê-se em Geografia (LOPES, 2002, p. 260).

Ao mesmo tempo, o estudo mostra como, por trás do jogo de oposição, existe uma relação de correspondência, na qual elementos conflitantes habitam a mesma realidade. Analisando o poema "Marinheiro sem Mar", é possível perceber que mar como espaço de felicidade ("serena praia de mãos puras") e cidade como lugar de dor e sofrimento ("obscuras ruas da cidade sem piedade") só existem porque um tem ao outro como referência. Também é oportuno lembrar que o "marinheiro" - que tem a palavra mar na sua designação - é sem mar, portanto, é tirado dele aquilo que o define, que o faz "marinheiro". Para reiterar uma perspectiva original de Heráclito sobre a identidade dos opostos, recorre-se a Octavio Paz, que, em O Arco e a Lira, chama a atenção para o princípio da contradição complementária, a qual aponta para a interdependência existente entre os termos contrários, pois uma coisa só existe em função do seu oposto: "Cada termo pode se atualizar em seu contrário, de que depende em razão direta e contraditória” (PAZ, 1982, p.122).

Ao encontro de outra perspectiva dada por Octavio Paz, de que uma mesma imagem poética pode ser regida pela pluralidade, o trabalho aponta para a capacidade de reunir significados contrastantes, como acontece no poema "Cidades e Ciladas", publicado em 1983, na obra Navegações:

\author{
Cidades e ciladas \\ Mas também \\ O pasmo de tão grande arquitectura \\ As sedas os perfumes a doçura \\ Das vozes e dos gestos
}


Os grandes pátios da noite e sua flor De pânico e sossego

Enquanto no primeiro verso, o espaço urbano é apresentado como ambiente de armadilhas e traições - "Cidades e ciladas" - no segundo verso, uma leitura completamente inversa - porém coexistente - se anuncia. Pela combinação de uma conjunção adversativa ("Mas") com um advérbio que, nesse contexto, reforça o contraponto ("também"), a outra imagem da cidade a da suntuosidade e da grandiosidade - logo se revela: "O pasmo de tão grande arquitectura".

Haja vista a importância do tópico, como se tem visto até aqui, importa notar que o pesquisador Carlos Ceia (1996) também observa a coexistência dos opostos, apontando para a unidade presente nas relações dualistas que permeiam a obra da autora: "[...] o Poeta garante-nos que assim, através da tensão entre as partes, maiores serão as probabilidades de percebermos a unidade que as formou" (p.146).

Essa concepção da imagem como um fenômeno capaz de abarcar sentidos distintos e até mesmo contrastantes orienta a análise que se faz das variadas feições que o espaço urbano adquire em diferentes momentos da poética de Sophia. Seguindo essa leitura, o estudo apresentará três perfis distintos de cidade, as sedutoras, as babilônicas e as pós-apocalípticas.

Compõem o primeiro grupo, os espaços urbanos que se caracterizam pela ideia da sedução exercendo um misto de atração e repulsa no sujeito poético. Nessa parte da discussão ganha fôlego uma análise do magnetismo exercido por esses espaços e a dialética das cores, luzes e brilhos em contraposição à artificialidade que ronda um espaço revestido de esplendores falseados.

Apresentadas como uma espécie de antítese de Jerusalém, as cidades Babilônicas constituem um espaço de hostilidade para o sujeito poético. Nele, aflora o lado mais negativo da ação corruptora e degradante do homem no mundo. Ambiente propício às perversões, esse perfil de cidade surge muitas vezes como um lugar condenado à escuridão. É o que se vê no poema "Cidade alheia": nela o sujeito surge como um ser confinado e solitário, capaz de 
corromper até mesmo elementos inerentes ao meio natural quando deslocados para o meio urbano.

O terceiro grupo é composto pelas cidades que se aproximam da imagem do espaço urbano que emerge do apocalipse. Opondo-se à imagem da cidade pecadora, esse espaço é caracterizado pela claridade natural de um meio no qual não se encontra nenhum resquício de artificialidade. Espaço de júbilo e contentamento para o sujeito poético, essa espécie de cidade délfica é habitada pela harmonia, pureza e beleza, contrapondo-se à sua variante babilônica à medida que constitui um espaço de liberdade para o sujeito poético.

Essas breves observações ilustram como o presente trabalho desenvolve, nas páginas seguintes, uma leitura da configuração da cidade na obra da poeta, mostrando como esse ambiente se articula com o mar e identificando como o sujeito poético se coloca diante das três leituras possíveis desse mesmo espaço. 


\section{A poética de Sophia}

Nascida no Porto, ou como ela mesma dizia, "entre a cidade e o mar", Sophia de Mello Breyner Andresen, ou simplesmente Sophia, como é referida em Portugal, manteve desde sempre uma relação íntima com o real e todas as suas vicissitudes. Lembrando que, quando se fala em "obsessão pelo real" na obra da poeta, o que está em discussão não é em hipótese alguma sua mera descrição ou representação, mas sim o que Luís Miguel Nava aponta em um de seus ensaios sobre a poeta, como uma realidade que, de tão intensa, chega a abalar a própria subjetividade, numa expressão poética que nasce da escuta.

\footnotetext{
Há um momento em que o visível ('a veemência do visível', 'o brilho do visível') se torna de tal modo violento, que deixa de poder ser captado, ou formulado, em termos de visão para ter de passar a sê-lo em termos de audição, transformando-se assim o que era um excesso de luz num excesso de som, isto é, num 'clamor', 'clamor de um sol inabitável', 'clamor de exáticos luares' (2004, 175).
}

Da paisagem natural ao espaço urbano, do tempo mítico primordial ao tempo em que até a voz do mar se tornou exílio durante as mais de quatro décadas de ditadura salazarista, o fato é que na obra da autora, o real surge em todos os seus ângulos, numa tessitura poética avessa a qualquer tipo de enquadramento.

Marco importante da literatura de seu país, a poeta falecida em 2004 compõe, ao lado de nomes como Eugénio de Andrade e Jorge de Sena, uma espécie de grupo canônico da poesia portuguesa contemporânea. Nascida em 1919, quando o mundo começava a voltar ao seu ritmo natural após sair da Primeira Grande Guerra, Sophia seguiu na contramão desse momento de euforia, para dedicar um olhar atento ao universo e às suas formas naturais. Ao longo de quase sete décadas de produção poética, ela soube, como poucos, canalizar sua inspiração para o essencial que permeia a existência humana e nele encontrar sua própria biografia: "Procurei-me na luz, no mar, no vento" ("Biografia", Mar Novo).

Dessa obsessão pelo real, aspecto que será abordado em pormenor mais adiante ainda no presente capítulo, Sophia terminou por agregar diversos 
elementos à sua obra. Da infância passada na terra natal e das férias na praia da Granja ficaram memórias que a acompanharam ao longo de toda a trajetória. Na vida da poeta, a união entre o real e a poesia se deu desde tenra idade, quando ela não imaginava que os poemas fossem obra humana, acreditando que, assim como o mar e a natureza, eles simplesmente existiam:

Eu era de fato tão nova que nem imaginava que os poemas eram escritos por pessoas, mas julgava que eram consubstanciais ao universo, que eram a respiração das coisas, o nome deste mundo dito por ele próprio (ANDRESEN, 2004, p. 270) ${ }^{1}$.

A mesma espontaneidade também permeou a relação que manteve desde sempre com a arte poética. Antes de conhecer a literatura, Sophia conheceu a poesia, como ela mesma conta: "Na minha infância, antes de saber ler, ouvi recitar e aprendi de cor um antigo poema tradicional português chamado 'Nau Catrineta'. Tive assim a sorte de começar pela tradição oral" (2004).

Dessa época, ficaram lembranças da infância. Entre tantas reminiscências, um elemento, em especial, entrelaçou-se à trama poética de Sophia de forma singular, o mar: "De todos os cantos do mundo / Amo com um amor mais forte e mais profundo / Aquela praia extasiada e nua, / Onde me uni ao mar, ao vento e à lua" ("Mar", Poesia, 1944).

Apontado por Alexei Bueno como o grande cerne da obra da poeta, o elemento marítimo é um tema privilegiado na criação de Sophia. Salvação e perdição, ao mesmo tempo que representa a sagração de conquistas (fonte de alimento e via de descoberta de novas terras), o mar também simboliza a morte dos que sucumbem às artimanhas de suas águas.

Foi justamente em meio a essa inspiração que Sophia começou a escrever seus primeiros poemas, já nos tempos de colégio. A estreia na cena literária portuguesa contemporânea se deu em 1940, no fascículo inaugural dos Cadernos de Poesia, organizados por Jorge de Sena, José Augusto França, José Blanc de Portugal e Ruy Cinatti. Habituados a dar preferência aos poetas

\footnotetext{
${ }^{1}$ Lido na Sorbonne, em Paris, em dezembro de 1988, por ocasião do encontro Les Belles Étrangères.
} 
inéditos, os Cadernos nem por isso deixavam de valorizar o que a tradição tinha a oferecer. Seguindo o lema de que a poesia era uma só, independentemente de escolas literárias, estéticas e doutrinas, essas publicações estavam além de qualquer estereótipo ou enquadramento. Os Cadernos defendiam a autonomia dos valores literários. Alinhados aos valores existenciais em voga, refletiam também o compromisso do ser humano com o seu tempo e sua cultura.

Prevendo ou não a posição que Sophia viria a ocupar na cena literária contemporânea, hoje é consenso que os Cadernos estrearam em grande estilo ao revelar uma autora que acreditou como ninguém na idéia de independência do texto poético. Como a própria Sophia conta, a poesia é uma arte que não pede ciências, nem estéticas e tampouco teorias: "Pede-me uma intransigência sem lacuna. Pede-me que arranque da minha vida que se quebra, gasta, corrompe e dilui uma túnica sem costura" ("Arte Poética II", p. 189).

Quatro anos depois de estrear no referido periódico, foi a vez de a poeta publicar seu primeiro livro, Poesia. Numa edição de autor, custeada pelo pai, Sophia deu início a uma produção literária que se manteve fértil ao longo de toda a vida. Permeada por uma riqueza imagística povoada por árvores e ventos, praias e mar, noite e sol e, ainda, norteada por uma exigência ética rigorosa, a poesia de Sophia, segundo autores como Jorge de Sena e Eduardo Prado Coelho, repele a análise e cria um silêncio em torno de si (CEIA, 1996, p. 25-27).

Nesse sentido, é interessante atentar para um aspecto em especial. Se, de um lado, o crítico habituado a submeter o objeto literário a enquadramentos vê nesses aspectos um problema, é justamente dessa relação de características tão impalpáveis que emana a singularidade da obra poética de Sophia. Ao mesmo tempo que é influenciada pela mítica Grécia, a obra da autora salta no tempo e floresce no 25 de abril. Essa mesma oscilação se faz presente nas relações antagônicas de vida e morte, luz e trevas e tantos outros elementos que, ao mesmo tempo que rivalizam entre si, se complementam. Nessa poesia que busca a harmonia dos contrários, os deuses cristãos dividem espaço com os pagãos que, aliás, são outra presença marcante em sua obra poética. Longe de ser fruto do acaso, a presença dessas divindades, dos motivos helênicos e dos conceitos clássicos de harmonia, inteireza e justiça 
podem ser, em parte, reflexo da experiência que Sophia adquiriu entre 1936 e 1939, quando freqüentou o curso de Filologia Clássica na Faculdade de Letras da Universidade de Lisboa. Apesar de jamais ter concluído a graduação, esses três anos tiveram um impacto indiscutível em sua obra, como se verá mais adiante numa leitura do tom saudosista que o mundo grego assume na obra de Sophia frente a uma realidade presente que divide e separa.

A propósito da perspectiva do presente aterrador como uma marca incisiva na obra da poeta, é interessante observar como essa leitura tomou forma nos anos de ditadura salazarista. Aliás, um acontecimento que de certa forma refletiu na obra poética da autora foi o casamento com o jornalista e político Francisco Sousa Tavares, em 1946. O convívio com o marido intensificou o ponto de vista crítico de Sophia em torno da realidade de seu país. Num cenário em que Portugal vivenciava as agruras do regime autoritário, as questões sociais do seu tempo assumiram o primeiro plano em versos de resistência: "Quando a pátria que temos não a temos / Perdida por silêncios e por renúncia / Até a voz do mar se torna exílio / E a luz que nos rodeia é como grades" (“Exílio", Livro Sexto).

Opositora atuante daquele que foi o mais longo período ditatorial da Europa Ocidental do século XX, Sophia foi co-fundadora da Comissão Nacional de Socorro aos Presos Políticos. Com o fim do regime que vigorava desde 1926, em 25 de abril de 1974, foi deputada pelo Partido Socialista na Assembleia Constituinte. Quando falava da Revolução dos Cravos, Sophia fazia questão de enfatizar que fora um dos momentos de máxima alegria em sua vida: "Foram dias que vivi em estado de levitação. Isso aliás aconteceu a muita gente" (COELHO, 1987, p.74).

Tanto contentamento não poderia ter outra forma de expressão que não fosse o verso, grande ofício da poeta: "Esta é a madrugada que eu esperava / O dia inicial inteiro e limpo / Em que emergimos da noite e do silêncio / E vivos habitamos a substância do tempo" ("25 de Abril", 0 nome das coisas).

No entanto, nos anos que seguiram, a perspectiva de um futuro regenerador acabou se perdendo. Aos olhos da poeta, Portugal continuou sendo uma nação por fazer: "Creio que houve um estado de graça. Mas depois, o pecado do poder destruiu esse estado de graça", conta a autora em entrevista ao Jornal de Letras, Artes e Ideias (1982, p.4). Dos tempos em que 
esteve na Assembleia Constituinte, a própria Sophia recorda um episódio que viria, mais uma vez, a revelar o papel transgressor e transformador da literatura:

\begin{abstract}
Saí um dia mais cedo e atravessei o Bairro Alto a pé. Na rua havia um pequeno grupo de crianças a brincar na soleira de uma porta. E chamaram-me e perguntaram me se eu era a Sophia de Mello Breyner Andresen. E eu disse que sim, mas como é que elas sabiam? Elas responderam que a professora estava a ler uma história minha na aula e tinham visto um retrato meu. Fiquei a conversar com as crianças - e pensei, de repente, que escrever era a minha verdadeira participação política (Jornal de Letras, Artes e Ideias, 1982, p.4).
\end{abstract}

Hoje, sete anos após a morte de Sophia, sua poesia continua "pressentindo" o que Fernando Pinto do Amaral define num artigo publicado no "Jornal de Letras, Artes e Ideias" como "o próprio mistério das coisas" (AMARAL, p.7). Ao longo de tantas décadas de produção, a poeta vencedora do Prêmio Camões em 1999 transitou também pelos meandros da prosa, na qual se revelou exímia contista. Mas de toda essa claridade e transparência que emana da obra literária de Sophia é na poesia que ela realmente revela a essência de uma criação elementar, que se nutre do real em todas as suas vicissitudes. E desse olhar atento emerge uma obra poética que se distancia das nomenclaturas para trazer à tona uma criação que, em diversos aspectos, expressa a busca pelo real, num contexto em que, conforme observa Silvina Rodrigues Lopes: "O que se apresenta não é o real como um todo, mas sim as coisas reais, ou as coisas na sua participação do real, no seu 'ser real" (2003, p.51).

Nesse sentido, dentro da criação poética da autora, é interessante observar a busca do sujeito poético por reter o efêmero nas malhas do texto. Considerando a percepção da escritura de um espaço cambiante, convém observar a leitura do poeta e ensaísta Octavio Paz (2005) em torno da capacidade do poema de reter aquilo que é efêmero por natureza: "Em sua rotação o poema emite luzes que brilham e se apagam sucessivamente" (p.282). 
Tal noção do fugidio e do contingente traz à luz a capacidade do poema de reter o transitório, que se manifesta como lampejos de um real a fazer-se e desfazer-se instantaneamente:

[...] a cristalização corresponde à intensidade com que o presente simultaneamente se mostra e se dissolve: a modernidade encontra na experiência da cristalização uma das suas imagens emblemáticas (BUESCU, 2005, p.29).

Ao considerar a própria natureza do processo de cristalização em seu sentido primário, o da ciência, Buescu estabelece um paralelo com a leitura de tal fenômeno, mostrando a instabilidade comum a ambos:

Cristalizações: momentos precários de passagem do estado líquido ao sólido, que instavelmente fixam uma imagem num momento. $O$ que aqui começa a me interessar é sobretudo o facto de que essa fixação essencial (porque sem ela não há cristalização) é instável por natureza (trata-se de um sólido que pode voltar ao seu primeiro estado líquido) e, por isso, se pode dissolver na sua afinal ilusória, porque precária, forma fixa (o diálogo, como fica visto, é pois também, uma conversa que inclui a leitura que Berman faz da frase de Marx, all that is solid melts in the air). A cristalização é uma imagem presente: o presente é o momento do moderno por excelência, mas é também o seu tempus mais paradoxal, como Jameson deixa claro no capítulo final do seu livro, cujo subtítulo é, justamente, Essay on the Ontology of the Present. Imagem presente cujo brilho cristalino (a relação é aqui mais do que partilha etimológica), refletindo a luz, reflete também a sua precariedade (BUESCU, 2005, p.27).

Ao encontro dessa perspectiva é possível identificar na poesia de Sophia Andresen essa característica tanto pela via das imagens que o texto evoca, quanto por elementos rítmicos que convergem na capacidade do texto poético de plasmar momentos e sensações regidos pela brevidade e pela instabilidade. Alinhado a essa leitura, "No Poema", publicado em Mar Novo (1958), revela esse mesmo registro do efêmero.

A primeira estrofe desse poema composto por dois quartetos já remonta à leitura da poesia como um fenômeno que não representa, mas apresenta um objeto, num contexto em que as imagens poéticas oferecem o exato momento de percepção no qual o real é transposto para as malhas do texto: 
A flor o copo o brilho da madeira

E a fria e virgem liquidez da água

Para o mundo do poema limpo e rigoroso

Nesse contexto, convém observar que o real evocado no poema não se limita a elementos materiais do universo circundante do sujeito poético "quadro", "muro", "flor", "copo" - mas, principalmente, ao que pode ser sentido - como a "brisa" - ou é perceptível por meio dos sentidos, que captam a visão do "brilho da madeira", e a sensação táctil da "fria e virgem liquidez da água". Sobre essa característica na poética de Sophia, Luís Miguel Nava observa que

A intensidade com que as coisas se oferecem aos sentidos, ao ponto de as sensações daí resultantes transmutarem a sua natureza, faz com que nesta poesia os sentidos adquiram um relevo muito especial (2007, p.176).

É justamente essa aptidão para ir além da mera descrição ou representação que confere ao poeta capacidade de transferir o contingente e o fugidio "Para o mundo do poema limpo e rigoroso". Na segunda estância de "No poema", o poder desse texto de resguardar o transitório é reforçado. Os dois versos iniciais - "Preservar de decadência morte e ruína / O instante real de aparição e de surpresa" - já remontam ao papel da obra poética de conservar algo que é extremamente efêmero, o "instante". Ao materializar poeticamente essas percepções, o poema acaba retendo aquilo que é fugidio a ponto de "Guardar num mundo claro / O gesto claro da mão tocando a mesa".

Num contexto em que as imagens plasmadas no poema ressuscitam a perspectiva baudelairiana do "transitório, efêmero, contingente" (BAUDELAIRE, 2002, p. 26), convém atentar também para outro aspecto do texto: a supressão dos sinais gráficos de pontuação. Nota-se que em nenhum momento eles entram em cena. Nem mesmo a vírgula, indicada para uma pausa ligeira, é aplicada para listar elementos: "Transferir o quadro o muro a brisa/ A flor o copo o brilho da madeira [...] Preservar de decadência morte e ruína". Essa característica se articula com a perspectiva do poema como a escritura de um espaço cambiante no sentido de sugerir a ideia de instantaneidade. As imagens não são somadas, elas parecem se sobrepor umas às outras, como lampejos do real. Uma interpretação semelhante acerca do mesmo poema é oferecida por Silvina Rodrigues Lopes, que observa a procura por transferir 
certas coisas, inclusive algumas qualidades, para o mundo do poema, num contexto em que a poesia de Sophia se afasta do mundo tradicional para adentrar no universo do poema:

Mas a enumeração não vale como enumeração de objetos a acumular. Ela constrói a figura do concreto - a de haver as coisas ao alcance do corpo, do olhar ou da mão. Não temos aqui a descrição de um lugar identificável, mas a alusão a um lugar que, sendo um lugar preciso, vale pela sua insubstituibilidade por qualquer outro, e nessa medida é indescritível. Apenas o seu ser real pode ser aludido, através do recortar-se no verso de uma série de palavras, nomes, que, pelo vazio de sentido que as rodeia, resultante nomeadamente de se justaporem sem pontuação, sujeitas ao espanto de quem as lê, ganham uma autonomia que deixa em suspenso seu uso referencial (LOPES, 2003, p. 53-54).

Num contexto de modernidade em que o sujeito poético busca captar o transitório, o contingente, a história se configura diante desse indivíduo sob um prisma ao mesmo tempo fascinante e repulsivo, sobretudo porque se trata de um contexto em que ele vive o drama de não conseguir fixar (e conter) essa realidade. É esse o drama do sujeito poético de "As nereides" (Dual):

\footnotetext{
Pudesse eu reter o teu fluir, ó quarto

Reter para sempre o teu quadrado branco

Denso de silêncio puro

E vida atenta
}

$\mathrm{Na}$ passagem acima é possível identificar a personalização do quarto, aspecto que pode dar uma ideia de intimidade muito grande, seja porque o quarto é o espaço íntimo do sujeito, por excelência, seja porque quarto e sujeito estão tão intimamente ligados que o sujeito o quer reter. Além disso, a passagem "reter o teu fluir, ó quarto" permite outra observação: querer reter o fluir do quarto é transpor para um contexto o que é típico de outro contexto: a capacidade de fluir é uma propriedade do tempo e da água. O quarto, entretanto, não flui, porque é estático. Assim, é possível identificar nesse verso a transposição de ideias e o "Pudesse eu reter o teu fluir, ó quarto" pode sugerir uma vontade do sujeito poético de reter o tempo. O que chama a atenção no verso é a forma como se busca fazer isso. Se o quarto é o espaço íntimo por excelência, reter o fluir do quarto pode sugerir que o sujeito, no seu 
instante de intimidade máxima e na conjuntura espacial de intimidade máxima, quer reter o fluir das coisas.

É interessante observar como o sujeito luta para captar lampejos do real. $\mathrm{Na}$ estrofe abaixo, o verso "reter o brilho", que remete à visão, revela uma busca pela permanência de um elemento que capta a atenção do sujeito por meio dos sentidos. "Reter a queda / Das ondas sobre a areia", por sua vez, sugere a busca por captar algo extremamente passageiro, o cair das ondas. Além disso, a procura por apreender o fluir das coisas e o correr do tempo "Que dos meus ombros jamais tombasse o tempo" - também chama a atenção:

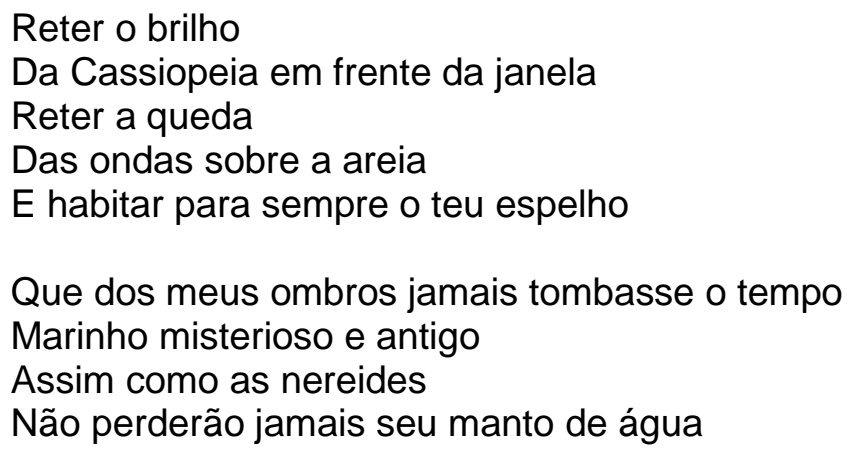

No trecho abaixo, extraído do poema "Paisagem", de Poesia, essa tentativa de captar o instante, o fugidio se dá tanto por meio de adjetivos que remetem à ideia de efemeridade, quanto por recursos sinestésicos:

\section{Passavam pelo ar aves repentinas, O cheiro da terra era fundo e amargo, E ao longe as cavalgadas do mar largo Sacudiam na areia as suas crinas.}

Era o céu azul, o campo verde, a terra escura, Era a carne das árvores elástica e dura.

Ao observar os versos em questão, Eduardo Prado Coelho chamou a atenção para a referência evidente aos sentidos, produzindo a comunhão das metáforas sinestésicas: "cheiro da terra fundo e amargo" (olfato/paladar), "céu azul, o campo verde, a terra escura" (visão), "carne das árvores elástica e dura" (tato).

Para o autor, a procura por captar o transitório também se revela na criação poética de Sophia Andresen pela busca por aquilo que está oculto, numa "tentativa de surpreender por um instante uma espécie de 
estremecimento abafado, de vibração oculta - como um olhar cego que subitamente se ilumina [...]" (1982, p.16).

Essa perspectiva vai ao encontro da situação vivenciada pelo sujeito no poema "Passam os carros e fazem tremer a casa", publicado em Coral. Já no próprio título, o eu retoma a questão da efemeridade reforçada pelo uso do verbo passar no presente do indicativo - "Passam os carros e fazem tremer a casa". Além de trazer de imediato uma imagem em tensão - carros em movimento versus casa (na qual segue incutida a ideia de estaticidade) - esse verso abriga a representação de que o que é estável e permanente é ameaçado por aquilo que é transitório, passageiro, fugaz.

Ainda na primeira estância, dois versos são a exata tradução da tentativa constante de reter nas malhas do texto o fortuito, 0 contingente, 0 transitório que permeia o real: "A forma gravada em vazio / Das vozes e dos gestos que outrora aqui estavam." É dessa maneira que o poema surge como uma alternativa para preencher uma lacuna que o sujeito não consegue - "E as minhas mãos não podem prender nada". Corrigindo as fissuras do real, ele retém aquilo que é fugidio por natureza.

Entretanto, é interessante observar como esse presente fugaz segue relacionado ao passado, na medida em que um tempo se reconhece no outro e se inscreve como fronteira revelando outros de si:

Talvez mais do que em si próprio, é na apropriação diferenciadora de outros tempos e de outros territórios que o presente se pode enfim (re)conhecer. É precisamente também neste sentido que as cristalizações do presente podem ser entendidas como fronteiras da modernidade: aquilo que 0 presente cristaliza como imagem e representação de si fala, subterrânea mas não menos agudamente, das imagens e representações dos outros de si (BUESCU, 2005, p.33).

A busca por captar o fugidio também aparece nos poemas que têm 0 mito de Orpheu e Eurídice como tema central, que somam um total de nove, sem contar as referências presentes em outros textos. Nesse sentido, é interessante chamar a atenção para um desses poemas, "Eurydice", publicado na obra No tempo Dividido, que permite estabelecer um paralelo entre o ofício do poeta e o próprio mito: 
Este é o traço que traço em redor do teu corpo amado e perdido

Para que cercada sejas minha

Este é o canto do amor em que te falo

Para que escutando sejas minha

Este é o poema - engano do teu rosto

No qual eu busco a abolição da morte

Composto por três dísticos sempre iniciados por uma construção anafórica, o poema ressalta a ânsia de Orfeu (poeta) por encontrar sua amada, Eurídice (poesia). Da mesma forma que o personagem mítico busca incessantemente reter a amada [perdida], o poeta anseia por resguardar 0 instante, a sensação, o aroma, o som, enfim, uma infinidade de fragmentos do real que só a poesia e sua capacidade de apreender o transitório e o fugidio são capazes de eternizar.

Aliás, nesse momento, é interessante atentar para a estância que abre o poema, na qual é possível perceber o mesmo imperativo desejo de reter algo fugidio: "Este é o traço que traço em redor do teu corpo amado e perdido / Para que cercada sejas minha“. Tal passagem - que evoca o desejo de apreensão da poesia (Eurídice) pelo poeta (Orfeu) com o intuito de, por meio do poema, conseguir perpetuar o passageiro, o transitório - dialoga com uma frase muito conhecida de Sophia: "Um poema foi sempre um círculo traçado à roda duma coisa, um círculo onde o pássaro do real fica preso." Tal captura do real, segundo Silvina Rodrigues Lopes, cria ao redor das coisas uma ressonância que "as faz ser":

Porque esse círculo é captura do incapturável - o pássaro do real, aquilo que não se vê porque é uma imagem da linguagem, o exceder da realidade pela sua representação poética ou poetização (2003, p.51).

Outro aspecto que demonstra que o poema vai além da temática mítica parte de uma característica pulsante dentro do próprio mito. Orfeu, que também era poeta, foi buscar sua amada no Hades, mundo dos mortos. Ocorre que esse mesmo espaço pode ser lido como uma metáfora do estado ideal do 
autor, no qual tudo pode ser visto com mais clarividência, constituindo o espaço da escrita do outsider.

Partindo da perspectiva que defende que "o autor deve apagar-se ou ser apagado em proveito das formas próprias aos discursos" (FOUCAULT, 2002, p.80), é possível dizer que no espaço de escrita, o poeta desaparece para dar voz às palavras". Num contexto em que Orfeu metaforiza o poeta e Eurydice, a poesia, o espaço do poema pode ser interpretado como o Hades, justamente porque nele o "autor cede, pois, o lugar principal à escritura" (COMPAGNON, 2006, p.50).

Nesse sentido, é interessante observar o poema "Penélope", que resgata uma das personagens mais emblemáticas da literatura universal para trazer à tona as vicissitudes da própria criação literária. Símbolo do destino, o ato de tecer aponta para as infinitas possibilidades que o fazer literário permite - "Tecer é criar novas formas" (CHEVALIER, 2007, p.872). Quando se considera a imagem de Penélope, a esposa de Ulisses que durante o dia tecia uma manta e à noite a desmanchava para adiar o casamento com um dos seus pretendentes, é possível estabelecer um paralelo com o poema, à medida que as tramas desfeitas pela esposa de Ulisses durante a noite e refeitas durante 0 dia podem ser interpretadas como as diferentes maneiras de se contar uma história ou ainda as infinitas possibilidades de histórias que um autor pode contar:

Desfaço durante a noite o meu caminho.

Tudo quanto teci não é verdade,

Mas tempo, para ocupar o tempo morto,

E cada dia me afasto e cada noite me aproximo.

("Penélope")

Ainda sobre o poema "Penélope", é interessante levantar outra reflexão acerca de um sujeito poético que ironicamente parece atingir o autêntico estado da escrita justamente ao destecer sua trama. Se, durante o dia, ele percorre um caminho falso apenas para preencher o tempo, à noite ele se aproxima da verdade do seu ser. Essa verdade também é a verdade almejada pelo autor, que precisa deslocar-se - daí o fato de renegar suas ações à luz do dia: "Tudo quanto teci não é verdade" - para escrever. Nesse sentido, Eliot já 
afirmava: "A evolução de um artista é um contínuo auto-sacrifício, uma contínua extinção da personalidade" (1989, p.42).

Em uma de suas Artes Poéticas, a autora descreve uma situação que vai ao encontro desse ponto de vista de Eliot, fundado na ideia de que o autor deve estar fora do mundo e de si mesmo na prática de seu ofício. A passagem que segue revela como se dá esse distanciamento entre aquele que escreve e o que é escrito na obra de Sophia:

No fundo, toda a minha vida tentei escrever esse poema imanente. E aqueles momentos de silêncio no fundo do jardim ensinaram-me, muito mais tarde, que não há poesia sem silêncio, sem que se tenha criado o vazio e a despersonalização.

Um dia em Epidauro - aproveitando o sossego deixado pelo horário de almoço dos turistas - coloquei-me no centro do teatro e disse em voz alta o princípio de um poema. E ouvi, no instante seguinte, lá no alto, a minha própria palavra, desligada de mim. Tempos depois escrevi estes três versos:

A voz sobe os últimos degraus

Oiço a palavra alada impessoal

Que reconheço por não ser já minha

(Sophia de Mello Breyner Andresen / Ilhas / "Arte Poética V")

A passagem acima revela o trabalho de distanciamento necessário ao ofício do poeta. É interessante observar como Sophia trabalha essa questão, tirando de uma experiência cotidiana e das próprias imagens poéticas de sua tessitura textual a tese que sustenta o argumento do autor como alguém que observa de fora. Eis que, como dizia Bachelard, "o poeta fala no limiar do ser" (2008, p.2).

Numa entrevista ao Jornal de Letras, concedida a José Carlos Vasconcelos, ao comentar esses versos, a poeta reitera que esse deslocamento surge como uma consequência da própria poesia imanente que habita o real.

Conclui-se que o poema resulta de uma escuta atenta do real. Visto ser uma espécie de 'respiração das coisas, o nome deste mundo dito por ele próprio'. Assim, a nomeação do real efectua-se através do processo de despersonalização, isto é, da criação de uma voz impessoal que imediatamente se desprende do eu que a criou (Jornal de Letras de 25 de junho de 1991). 
Tal desprendimento, para Harold Bloom, também pode se apresentar como o grande drama da condição inexorável do sujeito poético, fadado à "la soledad de la conciencia y la conciencia de la soledad" (PAZ, 2000, p.17) daquele que habita o espaço intervalar entre o mundo dos homens e o mundo do autor no exercício da escrita.

No trecho abaixo, Bloom parte de uma seqüência de John Milton, no poema épico "Paraíso Perdido", também traduzido como "A Perda do Paraíso", para ilustrar o dilema do poeta que precisa se deslocar, sair de si, para atingir o estado da escrita, um estado próximo ao vivenciado por Orfeu em sua passagem pelo Hades: submundo, ambiente intervalar no qual tudo, uma vez visto de fora, pode ser observado com mais clarividência.

O poeta é o nosso eleito, e sua consciência de ter sido eleito é, para ele, uma maldição. Repetindo: não 'eu sou um homem caído', mas sim 'eu sou o Homem, e estou caindo'; ou melhor, 'eu era Deus, era o Homem (Para o poeta não há diferença) e estou caindo, para fora de mim mesmo'. E só quando essa consciência atinge uma intensidade máxima que o poeta toca no chão do Inferno. Diz, então: 'pareço não estar mais caído, conseqüentemente eis-me aqui prostrado no inferno' (BLOOM, 1973, p.51).

A exemplo dessa perspectiva, o segundo verso do poema "Passam os carros e fazem tremer a casa", publicado em Coral e já citado anteriormente, remonta à condição intermediária do sujeito poético na modernidade. No trecho a seguir, esse olhar do outsider se faz presente pela ótica de alguém a ocupar a região fronteiriça entre passado e presente:

\footnotetext{
Passam os carros e fazem tremer a casa

A casa em que estou só.

As coisas há muito já foram vividas:

Há no ar espaços extintos

A forma gravada em vazio
}

Na passagem acima, o sujeito poético mostra de imediato sua situação dentro da casa: "A casa em que estou só". É interessante observar como se coloca o seu ponto de vista. O eu não está centrado no presente, não está a caminhar entre os carros, ele está na casa de suas lembranças. E é por estar num lugar onde "as coisas há muito já foram vividas" e onde restam apenas 
"espaços extintos" que o sujeito também não se põe definitivamente dentro da casa. Ele está na região fronteiriça entre presente e passado. Fora do mundo (carros) e fora de si (casa do passado), ele ocupa um espaço intervalar, vivenciando a experiência do fora:

\author{
Mesmo para sofrer este tormento de não ser \\ Preciso de estar só. \\ [...] \\ Creio na nudez da minha vida. \\ Tudo quanto me acontece é dispensável.
}

A esfera intervalar associada à passagem de Orfeu pelo Hades também pode ser identificada no poema "Pirata". Já nos primeiros versos, o sujeito poético dá indícios dessa experiência, na medida em que está só: "Sou o único homem a bordo do meu barco". Somado a isso, esse indivíduo dá sinais do seu distanciamento do resto do mundo, um distanciamento que o torna superior os outros são "monstros" e não têm o dom da palavra, "não falam". No verso final a leitura desse sujeito como um outsider ganha ainda mais fôlego, na medida em que salienta a posição intervalar que ele ocupa: "E nunca acordo deste sonho e nunca durmo." Na passagem em questão, o sujeito se apresenta como um ser tangido pela instabilidade, daí sua condição intervalar:

Não pode deixar de hesitar e mover-se constantemente, em vaivém, entre as suas duas posições, não podendo conter-se nem fixar-se, em definitivo, em nenhuma delas (BUESCU, 2005, p.38).

É nesse sentido que o sujeito poético aparece em Sophia: não como um ser regido pelas influências do autor ou manipulado pelo texto, mas como um ser movido pela escrita. Nos versos abaixo, o sujeito parte de uma ideia daquilo que a arte/poesia não deve ser - nem manipulada pelo autor, agindo como um meio de "compensação", "transferência" e "refúgio" das frustrações, nem manipuladora do indivíduo - mas sim a pura expressão da palavra:

Que a arte não se torne para ti compensação daquilo que não soubeste ser

Que não seja transferência nem refúgio

Nem deixes que o poema te adie ou te divida: mas que seja

$A$ verdade do teu inteiro estar terrestre

("A casa Térrea", $\mathbf{O}$ nome das Coisas) 
Não por acaso, para Blanchot, poeta é aquele que "escutou essa palavra, aquele que se converteu na união, no mediador, aquele que impôs silêncio pronunciando-a" ${ }^{2}$ (BLANCHOT, s/d, p. 31). O autor ainda acrescenta que, uma vez pronunciada, essa palavra ganha vida; eis aí a despersonalização citada por Sophia:

A palavra poética já não é palavra de uma pessoa: nela ninguém fala e o que fala não é ninguém, mas parece que a palavra fala por si só ${ }^{3}$ (BLANCHOT, s/d, p. 35).

No exercício da escrita, o indivíduo que escreve se desfaz, dando lugar a um sujeito subordinado àquilo que escreve. "Escrever nos muda. Não escrevemos segundo o que somos, somos segundo o que escrevemos"4 (BLANCHOT, s/d, p. 81).

E é nesse sentido que o poeta, ao deslocar-se de si e do mundo, também experimenta as diferentes vivências poéticas. Exemplos dessa situação são as diferentes leituras de um mesmo elemento na obra de Sophia. A cidade e o mar, por exemplo, que serão abordados com mais profundidade no presente estudo, exemplificam bem essa situação.

Apresentado com uma conotação positiva em boa parte da obra da autora, o espaço marítimo também assume em alguns poemas feições negativas. Já a cidade, muitas vezes apresentada como espaço de infortúnio e sofrimento, revela também em algumas passagens um caráter dual, que transcende sua face aterradora para trazer à tona imagens de fascínio e encantamento. É nesse ponto que o sujeito poético revela suas peculiaridades:

Pois o poeta forte está condenado a descobrir suas ânsias mais profundas através da experiência de 'outros eus'. O poeta traz seu poema dentro de si, mas deve passar pela vergonha e pelo esplendor de se ver achado pelos poemas - grandes poemas - exteriores a ele (BLOOM, 1973, p.57).

\footnotetext{
2 Tradução livre do seguinte trecho: "escuchó esa palabra, el que se convirtió en la unión, en el mediador, el que impuso silencio pronuciándola."

3 Tradução livre do seguinte trecho: "La palabra poética ya no es palabra de una persona: en ella nadie habla y lo que habla no es nadie, pero parece que la palabra sola se habla."

${ }^{4}$ Tradução livre do seguinte trecho: "Escribir nos cambia. No escribimos según lo que somos, somos según aquello que escribimos."
} 
Por falar em poeta, convém neste momento chamar a atenção para um aspecto que permite ler a poesia pela ótica da própria Sophia, por meio dos textos ensaísticos e das Artes Poéticas escritas pela autora. Já no ensaio "Poesia e Realidade", publicado na revista Colóquio / Letras em 1960, ela se debruçava sobre o fazer poético para trazer à tona a noção de uma poesia imanente:

\footnotetext{
Pois a poesia é a própria existência das coisas em si, como realidade inteira, independente daquele que a conhece. [...] Se o poeta procura tanto a solidão, não é só para fugir ao rumor e à agitação, mas também para ver as coisas, quando elas estão sozinhas.

$[\ldots]$

A emoção que sentimos ao entrar numa casa deserta ou num jardim abandonado é a emoção de ver que as coisas sem nós existem, na sua própria realidade, em si. É com esse em si que o poeta quer entrar em relação.

[...]

Essa relação com a realidade é essencialmente encontro e não conhecimento (ANDRESEN, 1960, p. 53).
}

Para Sophia, a essência do poeta é a união com essa "Poesia" imanente que permeia o real. No entanto, tal encontro nunca é total e a lacuna que impede a união entre o poeta e a Poesia é preenchida pelo poema, que surge como um elo:

\footnotetext{
O poema vem como um intermediário, é ele que torna possível que a poesia não se quebre contra os seus próprios limites. Podemos dizer por isso que o poema é liberdade. [...]

Não podendo fundir-se com o mar e com o vento, o poeta cria um poema onde as palavras são simultaneamente palavras, mar, vento. Não podendo atingir a união absoluta com a Realidade, o poeta faz o poema onde seu ser e a Realidade estão indissoluvelmente unidos. Por isso o poema é o selo da aliança do homem com as coisas (ANDRESEN, 1960, p. 54).
}

Ao encontro do ponto de vista defendido pela autora neste ensaio, 0 poema abaixo, publicado em Coral, aponta para o papel mediador do poema, ao colocar o sujeito poético em comunhão com as coisas.

Chamei por mim quando cantava o mar Chamei por mim quando corriam fontes Chamei por mim quando os heróis morriam E cada ser me deu sinal de mim 
Embalada pela percepção de uma poesia imanente a permear o real, Sophia tece a leitura de três sentidos distintos para esse fenômeno. O primeiro habita a esfera da própria realidade; o segundo, a da sua relação com o homem; e o terceiro, a da linguagem.

Chamamos poesia à Poesia em si, independente do homem. Chamamos poesia à relação do homem com a Poesia do Universo. E chamamos poesia à linguagem da poesia, isto é, ao poema (1960, p. 53).

Nesse mesmo ensaio, a autora portuguesa, para quem poeta nato é aquele que reconhece a poesia como "aquele que tem sede reconhece a água", defende a perspectiva da criação como uma necessidade:

De facto, um homem que precisa de poesia precisa dela, não para ornamentar a sua vida, mas sim para viver.

Precisa dela como precisa de comer ou de beber. Precisa dela como condição de vida, sem a qual tudo é apenas acidente marginal e cinza morta (1960, p. 53).

Mas é nas "Artes Poéticas" que as particularidades do fazer literário de Sophia aparecem com mais força para revelar uma criação que transcende estéticas e teorias. Fruto de uma consciência arguta do real, de uma fidelidade que se projeta além do controle de quem cria, o fazer poético, para Sophia, traduz-se como uma "intransigência sem lacuna", numa obstinação pelo real que somente a poesia é capaz de estabelecer:

Pois a poesia é a minha explicação com o universo, a minha convivência com as coisas, a minha participação no real, o meu encontro com as vozes a as imagens. Por isso o poema não fala de uma vida ideal mas sim de uma vida concreta: ângulo da janela, ressonância das ruas, das cidades e dos quartos, sombra dos muros, aparição dos rostos, silêncio, distância e brilho das estrelas, respiração da noite, perfume da tília e do orégão (ANDRESEN, 2004, p.189) .

$\mathrm{Na}$ passagem acima, extraída de "Arte Poética II", ao enumerar elementos do real transpostos para o poema, Sophia trouxe à tona um aspecto da modernidade analisado anteriormente em seus versos: a capacidade do texto poético de reter o efêmero, o contingente. Mas agora, o que se sobressai é o estilo de texto, mais próximo do ensaístico. "Ressonância das ruas", 
"distância e brilho das estrelas", "respiração da noite", "perfume da tília" e do "orégão" representam o efêmero, o transitório e o contingente que a imagem poética - seja ela sonora, visual, sinestésica - recupera.

A autora, que assim como Pound, inspirada na concepção original de Horácio, vê na criação poética um dos ofícios que fazem do artista as "antenas da humanidade" - "Pede-me que viva atenta como uma antena, pede-me que viva sempre, que nunca me esqueça" -, vê o poeta como um artesão da linguagem. Sophia sustenta que as palavras de um poema não foram escolhidas por acaso, "esteticamente ou por sua beleza", mas sim em virtude da sua própria realidade, da qual se desprende uma poesia imanente. E é nesse contexto que as palavras revelam poder poético, através do qual e com o qual são capazes de "estabelecer uma aliança" (ANDRESEN, 2004, p.190).

Ao discorrer sobre o fazer poético, a autora retoma uma afirmação de Fernando Pessoa - "Aconteceu-me um poema" - para resgatar a circunstância espontânea da qual nasce esse tipo de obra: "O poema aparece feito, emerge, dado (ou como se fosse dado). Como um ditado que escuto e noto" (ANDRESEN, 2004, p.213).

Segundo Sophia, o poema deve dizer-se por si, sem intervenção daquele que escreve, "como quem segue um ditado (que ora é mais nítido, ora mais confuso), é a minha maneira de escrever". Nesse "ditar" da tessitura poética, a autora conta que o chamado "estado de escrita" pode ser diagnosticado por uma forte sensação de plasticidade e por um intenso anseio diante do vazio - com as múltiplas possibilidades de preenchimento que ele permite, de modo que "O branco do papel torna-se hipnótico" (ANDRESEN, 2004, p.214).

É nesse anseio por preencher o vazio da folha em branco que a busca pelo real constitui um aspecto dominante na criação poética de Sophia. Ao estabelecer uma relação justa com as coisas a poeta procura atingir a unidade tão almejada, pela via da comunhão com o essencial: "Um dia serei eu o mar e a areia, /A tudo quanto existe me hei de unir" ("Em todos os jardins", Poesia).

Não por acaso, aos seus olhos, o apego ao essencial é a base do conhecimento da vida. É justamente dessa combinação que emana uma poesia simples e, ao mesmo tempo, carregada de profundidade, uma poesia 
que se faz canal entre o eu e o mundo, na medida em que "aproxima o olhar das coisas que vê" (AMARAL, 1999, p.7).

Essa característica tão marcante na criação poética de Sophia se revela nas tramas de versos em que o real se apresenta como a janela da verdade do sujeito poético: "O meu interior é uma atenção voltada para fora/ O meu viver escuta [...] Não trago Deus em mim, mas no mundo o procuro/ Sabendo que o real o mostrará" ("Poema", Geografia).

Segundo Helena Carvalhão Buescu, Sophia capta em sua obra a beleza da existência concreta do mundo: "É esta 'evidência do real' que teremos de reconhecer em todas as parcelas de realidade que seguiremos nesta poesia" (BUESCU, 2005, p.50).

Permeada pela percepção atenta do mundo, a obra poética de Sophia Andresen tem no olhar uma de suas vias de expressão mais recorrentes. Exemplo dessa característica, o poema "Vi florestas e dansas e tormentos", extraído da obra Dia do Mar, traz à tona uma percepção sinestésica do real que vai se desvendando por meio da repetição anafórica - representada pelo emprego do verbo 'ver' no pretérito perfeito do indicativo:

\footnotetext{
Vi florestas e dansas e tormentos, Cantavam rouxinóis e uivavam ventos Nos céus atravessados por cometas.

Vi a luz a pique sobre as faces nuas, Vi olhos que eram como fundas luas Magnéticas suspensas sobre o mar. $[\ldots]$
}

Nos versos acima, o real surge desnudado pela voz de um sujeito poético que faz da visão seu ponto de referência para percepção do real. Através do olhar, ele enxerga o mundo em sua essência dual, na qual a perspectiva do belo e do prazeroso - "florestas e dansas" - divide espaço com aquilo que é da ordem do sofrimento e do pavoroso - "tormentos". Pela via do olhar, esse indivíduo também desnuda o real e o apresenta sob a luz de uma claridade impressionante: "Vi a luz a pique sobre as faces nuas".

Mas apesar de muitas vezes manifestar-se pelo olhar, essa comunhão com o real também faz uso de outros sentidos para ganhar forma: "A poesia de Sophia de Mello Breyner Andresen é uma poesia que se conjuga em torno da 
escuta, porque acredita que pode escutar os sons do mundo" (BUESCU, 2005, p. 51). A própria escritora, em "Arte Poética IV" (Dual) diz: "O poeta é um escutador". Segundo Helena Carvalhão Buescu, "o mundo fala, e o Poeta escuta - e escuta para depois também dizer" (2005, p.51-52).

Nessa percepção do real, Sophia traz à luz uma legião de sujeitos que, inspirados no mundo, distanciam-se cada vez mais da consciência do autor para se aproximarem daquilo que o meio externo tem para oferecer, como nestes versos da estrofe inicial do poema "Mar" (Poesia), que além de exemplificar a atenção voltada o real, enfatiza a comunhão que o sujeito busca:

\author{
De todos os cantos do mundo \\ Amo com um amor mais forte e mais profundo \\ Aquela praia extasiada e nua, \\ Onde me uni ao mar, ao vento e à lua.
}

Nesse sentido, além da própria experiência do fora, convém chamar atenção para a influência incisiva do olhar sobre o mundo na configuração de um sujeito poético que se desdobra em vários: "E, simultaneamente, um mundo de eus esvaziados e virados para a fascinação do exterior" (COELHO, 1982, p.31).

$\mathrm{Na}$ obra da poeta, outra característica marcante é a dualidade que habita o real, do qual a ideia de inteireza surge como uma mescla de esplendor e dor, conforme observa Helena Carvalhão Buescu:

Mas desta mesma 'felicidade nua e inteira' - e mais tarde voltaremos a este despojamento que é inteireza - decorre, de forma funda e verdadeira, a consciência da infelicidade (BUESCU, 2005, p.53).

Num contexto em que os elementos díspares coexistem dentro da mesma realidade, o conceito de identidade dos contrários apresentado por Octavio Paz pode ser aplicado à obra de Sophia, na medida em que a poeta portuguesa cria o que António Manuel dos Santos Cunha interpreta como, "quadros opostos de onde emergem uma complementaridade vital" (CUNHA, 2004, p. 21).

Segundo o poeta e ensaísta mexicano, a oposição também se revela capaz de unir, na medida em que uma coisa só existe em função do seu 
oposto. Trata-se de uma relação de interdependência, na qual a afirmação só existe diante da negação:

Todas as nossas empresas se orientam para descobrir o 'velho caminho', a via esquecida da comunicação entre os dois mundos. Nossa busca tende a redescobrir ou verificar a universal correspondência dos contrários, reflexo de sua identidade original (PAZ, 1982, p.126).

Quando se observa o raciocínio de Octavio Paz é impossível não associá-lo ao contexto da obra de Sophia Andresen, à medida que é evidente em sua tessitura poética a busca pelo real em sua completude, a procura pela verdade oculta nos antagonismos. O poema "Fundo do Mar", publicado na obra Poesia, exemplifica essa situação desde o primeiro verso: "No fundo do mar há brancos pavores". Na passagem em questão o ambiente marítimo é habitado por algo que, ao mesmo tempo que remete à calma, sugerida pela cor branca, apresenta uma natureza assustadora, "pavores":

No fundo do mar há brancos pavores,

Onde as plantas são animais

E os animais são flores.

Mundo silencioso que não atinge

A agitação das ondas.

Abrem-se rindo conchas redondas,

Baloiça o cavalo-marinho.

Um polvo avança

No desalinho

Dos seus mil braços,

Uma flor dança,

Sem ruído vibram os espaços.

Sobre a areia o tempo poisa

Leve como um lenço.

Mas por mais bela que seja cada coisa

Tem um monstro em si suspenso.

Ao longo do poema coexistem também estados que aludem ao sossego - "Mundo silencioso" - e alvoroço - "agitação das ondas". Vale ressaltar que ambos estão contidos no mesmo espaço e, ainda assim, existe uma 
convivência harmoniosa entre eles - "Mundo silencioso que não atinge / $\mathrm{A}$ agitação das ondas."

A estrofe final, que é um dístico, encerra o poema com a mesma ideia do verso inicial: a correspondência dos contrários - "Mas por mais bela que seja cada coisa / Tem um monstro em si suspenso." No trecho em questão, o belo e o grotesco habitam uma mesma imagem. Essa leitura é salientada na análise de António Manuel dos Santos Cunha:

Na poesia de Sophia de Mello Breyner Andresen, a veemente atenção sobre o real só faz sentido se permitir o encontro pleno com um conjunto de múltiplas e diversificadas dimensões dialecticamente erigidas através da confluência de caos e ordem, de luz e sombra, de serenidade e delírio (CUNHA, 2004, p.118).

Seguindo a mesma perspectiva, Helena Carvalhão Buescu fala dessa dualidade como algo necessário, num contexto em que cada coisa precisa do seu oposto para afirmar sua existência. Essa dualidade onde o fundo do mar é habitado por algo que causa ao mesmo tempo fascínio e assombro faz parte do próprio real que essa poesia se põe a apresentar, conforme observa Buescu:

Esta arte poética é pois a de uma presença que não exclui, no entanto, pelo contrário, a consciência da ausência, de novo luz e sombra. Leiamos a esta luz o poema 'Um poeta clássico' (Geografia): 'Um poeta clássico/ Fará da ausência uma parte do seu jogo/ Nem integrada nem assumida/ Apenas companheira/ Segunda mão poisada sobre a mesa/ Mão esquerda'. Assim, e sendo a ausência necessária à presença, podemos dizer que o contraste e o avesso dela, uma certa arte poética (que epíteto 'clássico', no interior da poesia de Sophia, significativamente qualifica) poderá elegê-la como companheira', antropológica 'mão esquerda' - a mão que diz ao mesmo tempo de si e da mão direita. O poema diz de si e do mundo, de forma tão intrinsecamente moldada como aquela. Olha e é olhado, numa aparição de presença que apenas a poesia sabe discernir e comunicar (BUESCU, 2005, p.63).

É nesse sentido que os opostos perfazem, nas fissuras do real contraditório por natureza, uma relação complementar fundada na busca pela unidade original perdida no tempo presente. Tal perspectiva também vai ao encontro da leitura de Carlos Ceia, que no excerto abaixo comenta de que 
maneira a cisão se revela também uma forma de estabelecer uma relação harmônica:

Tudo está dividido, incluindo o próprio tempo. Este é um princípio de organização interna do mundo de Sophia. A própria unidade original tão ambicionada se dividiu em si mesma, porém o Poeta garante-nos que assim, através da tensão entre as partes, maiores serão as probabilidades de percebermos a unidade que as formou. Tudo está dividido, mas também relacionado entre si, pois que tudo está sujeito a uma contínua transformação no seu oposto: o activo em passivo, a vida em morte, ordem em caos, etc., havendo, contudo, um equilíbrio silencioso que persiste nas combinações dualistas (CEIA, 1996, p. 146).

Para ilustrar os comentários tecidos até aqui e a leitura crítica destacada, apresenta-se o poema "O jardim e a casa" (Poesia), que aponta para a conciliação dos opostos e para a natureza que rege essa relação antagônica, porém jamais excludente:

Não se perdeu nenhuma coisa em mim.

Continuam as noites e os poentes

Que escorreram na casa e no jardim,

Continuam as vozes diferentes

Que intactas no meu ser estão suspensas.

Trago o terror e trago a claridade,

E através de todas as presenças

Caminho para a única unidade.

É interessante observar como o poema sintetiza com clareza o conceito apresentado por Paz. A começar pela postura do sujeito poético, que já de início se apresenta como alguém que tem plena consciência da dimensão vária das coisas que compõem o real: "Não se perdeu nenhuma coisa em mim". Na sequência, ele segue paulatinamente abrindo brecha para sua leitura dual do mundo. As "noites e os poentes" escorrem tanto no espaço criado pelo homem - a "casa" -, quanto no espaço natural - o "jardim". O próprio sujeito faz questão de enfatizar as "vozes diferentes". Mas, ao mesmo tempo que se apresenta tomado pela dimensão do heterogêneo, o "eu" poético adverte que não se deixa pender por nenhum dos lados: "Continuam as vozes diferentes / Que intactas no meu ser estão suspensas." Entretanto, são os versos finais que caminham decisivamente para o conceito de unidade que define e contém 
os antagonismos: "Trago o terror e trago a claridade, / E através de todas as presenças / Caminho para a única unidade."

Dessa forma, a obra de Sophia reforça o conceito de unidade presente na relação de coexistência entre os opostos, de modo que ao enxergar essa complementaridade que habita os jogos de oposição, a poesia une o que o real separa, corrigindo-o em sua natureza precária:

Porque a procura (ou sabedoria) da unidade implica também o saber da divisão, numa espécie de complementaridade indissociável que implica não recusar o que divide, porque por ele se pode saber o que une (BUESCU, 2005, p.65).

Nesse contexto, é importante salientar que, apesar da ideia de complementaridade intrínseca a esse jogo de oposições, persiste ainda a frustração de um sujeito poético cindido, na medida em que se dá conta da dualidade imanente do real. É justamente ao encontro desta constatação que a poesia surge como uma forma de preencher as fissuras do real: "Esta poesia de comunhão com o mundo e de participação no real busca a inteireza do ser humano" (CUNHA, 2004, p.35). Mas antes de aprofundar essa leitura do papel da poesia, convém observar as formas sob as quais essa tensão no reino do sujeito poético se configura.

Temática recorrente na obra da autora, a imagem do labirinto aparece nos poemas de Sophia com conotações variadas - espanto, errância, ausências, itinerário... - de modo que, ao mesmo tempo, se revela um meio, um caminho para uma busca atenta. Essa metáfora pode ser identificada na figura de elementos como "redes", "castelos", "corredores", "encruzilhadas", enfim, numa infinidade de imagens que remetem a "buscas vertiginosas", segundo António Manuel dos Santos Cunha. Apresentado como um espaço do qual o sujeito poético quer sair, o labirinto pode ser interpretado pela via tortuosa pela qual ele tem que passar nessa fuga. As imagens do poema "Maria Helena Vieira da Silva ou o itinerário inelutável" (Dual) aludem à perspectiva enclausurante desse ambiente:

Palácio é o labirinto e nele

Se multiplicam as salas e cintilam

Os quartos de Babel roucos e vermelhos

Passado é o labirinto: seus jardins afloram 
E do fundo da memória sobem as escadas

Encruzilhada é o labirinto e antro e gruta

Biblioteca rede inventário colmeia -

Itinerário é o labirinto

[...]

Representação de um sistema de defesa, o labirinto, segundo Chevalier e Gheerbrant, "anuncia a presença de alguma coisa preciosa ou sagrada." No poema em questão, essa busca pode ser identificada no universo almejado pelo sujeito, além das muralhas do labirinto. Mas outra leitura possível desse espaço aponta para os mistérios da personalidade humana:

O labirinto também conduz o homem ao interior de si mesmo, a uma espécie de santuário interior e escondido, no qual reside o mais misterioso da pessoa humana (CHEVALIER e GHEERBRANT, 2007, p.531).

Ao encontro dessa leitura, outra imagem associada ao labirinto - o palácio - apesar de comumente relacionada à ideia de magnificência, simboliza também os três níveis da psique: "o inconsciente (o segredo), o consciente (o poder e a ciência) e o subconsciente (o tesouro ou ideal)" (CHEVALIER E GHEERBRANT, 2007, p.679). Não por acaso, ele surge acompanhado por diversas metáforas que convergem não só para a leitura da amplidão - "Se multiplicam as salas e cintilam" - mas também para algo cujas teias são infindas, a memória: "E do fundo da memória sobem as escadas".

Essa perspectiva aprisionante atinge seu ápice no décimo e no décimo primeiro versos do poema, quando várias metáforas constituem o itinerário aprisionador ao qual está fadado o sujeito poético: "Encruzilhada é o labirinto e antro e gruta / Biblioteca rede inventário colmeia".

No entanto, a perspectiva do labirinto como uma via tortuosa e apavorante não é a única leitura possível desse espaço. Ele também pode ser interpretado como uma metáfora da vida, na medida em que o labirinto pode ser lido como uma travessia difícil a ser feita pelo sujeito poético em busca de um estado de plenitude. Em sua leitura do poema "Maria Helena Vieira da Silva ou o itinerário inelutável", António Manuel dos Santos Cunha aponta para a percepção daquele espaço como uma via para a realização, que sinaliza a capacidade do sujeito poético de "vencer a voragem do labirinto" (2004, p.68). Para o crítico, 
[...] a última estrofe do poema diz-nos que o labirinto não é o fim, mas o começo, pois, 'um dia', o caminho percorrido no interior do sombrio labirinto conduzirá a um centro que assinala a libertação plena, evocada no mito através do combate vitorioso de Teseu com o insaciável Minotauro, e de onde é possível emergir e encontrar as cidades da 'equidade', que mais não serão que 'as cidades acesas na distância, / Magnéticas e fundas como luas' (CUNHA, 2004, 67-68).

Nesse ponto, convém antecipar um tópico que será retomado com mais profundidade adiante, ainda neste capítulo, apenas para revelar mais claramente a leitura do labirinto como metáfora da vida e o papel desempenhado pela poesia nesse contexto. Se o sujeito poético luta para sair desse espaço aprisionante e angustiante, ele o faz pela via da palavra, como destaca o crítico citado: "Sendo o labirinto metáfora da vida humana onde tragicamente o homem se perde, a aliança só poderá ser tecida pelo 'fio de linho da palavra', contínuo e inquebrável" (CUNHA, 2004, p.81).

Desse modo, observa-se que a poesia da autora em nenhum momento sugere a negação do labirinto e de nenhum outro elemento que atormente 0 sujeito poético. O que se vê em sua criação é a consciência plena de que esses espaços de dor e sofrimento coexistem com seus opostos e que a travessia desse sujeito por eles é não só inevitável como necessária em determinados momentos: "Sozinha caminhei no labirinto / Aproximei meu rosto do silêncio e da treva / Para buscar a luz dum dia limpo" ("Labirinto", Livro Sexto). Esses versos mostram ainda que, além de inevitável e necessário, "caminhar no labirinto" é imprescindível como processo catártico: o sujeito aproxima-se do "silêncio e da treva" para "buscar a luz dum dia limpo" e, quiçá, encontrá-la - como é possível depreender da concretude da "luz dum dia limpo".

Independentemente do percurso a ser enfrentado, o que importa para esse sujeito é resguardar o elo original com o primordial. Para Coelho,

Sophia não recusa o labirinto, a noite, a morte ou quaisquer outras figuras da negatividade, desde que o fio de que se tece essa túnica sem costura (que é a infância, o mar, o paraíso e a poesia) se não rompa, se não quebre: 'Perfeito é não quebrar / A imaginária linha'. Ou Sophia poderá associar o tecido do 
poema e o tecido da túnica e atribuir-lhes a pureza que se desprende do linho: 'pertenço à raça daqueles que percorrem o labirinto / Sem jamais perderem o fio de linho da palavra' (COELHO, 1982, p.27).

A "atenção voltada para fora", da qual fala a autora em "Poema" (Geografia), se dá por meio do que Maria Armanda Passos chama de "olhar iluminado e solidário com o real", segundo ela, "um dos traços mais importantes na estruturação de um poeta como Sophia" (PASSOS, 1999, p. 6).

Nesse momento é pertinente observar como essa percepção da realidade também toma forma sob diversos elementos advindos da cultura grega presente na obra de Sophia. Observa-se que a relação que a poeta tece com Grécia está fundada não apenas no ponto de vista estético, mas também no ético. A ideia do mito, por exemplo, é uma constante em sua criação literária, surgindo muitas vezes com a conotação de um tempo harmonioso em que o homem se encontrava em perfeita sintonia com os deuses e com o universo, a exemplo do que analisa António Manuel dos Santos Cunha:

\footnotetext{
O mito conduz-nos a um tempo arquetípico, em que a aliança entre o humano, o divino e a natureza é naturalmente estabelecida através da beleza, do canto e da música, numa eufórica celebração dessa ordem do mundo. Assim, a poesia, ao emergir sob o signo de Orfeu, adquire uma dimensão mágica 'enquanto forma de projeção assimiladora e de dominação do mundo', mas só estará ao alcance daqueles que conseguirem tecer a harmoniosa e justa aliança com o cosmos, à semelhança do 'primeiro homem', que 'Era como uma árvore da terra nascida / Confundido com o ardor da terra a sua vida' (CUNHA, 2004, p.45).
}

Segundo o estudioso da obra da poeta, essa fascinação pelo mundo grego está presente tanto na geografia reverenciada nos poemas, quanto na arte, nos monumentos e lugares sagrados; tanto na beleza harmoniosa, quanto no pensamento ético e racional. Exemplo desse esplendor que desperta fascínio no olhar do sujeito poético aparece no poema "Dionysos" (Dia do mar):

Entre as árvores escuras e caladas

O céu vermelho arde,

E nascido da secreta cor da tarde

Dionysos passa na poeira das estradas. 


\begin{abstract}
A abundância dos frutos de Setembro
Habita a sua face e cada membro

Tem essa perfeição vermelha e plena,

Essa glória ardente e serena

Que distinguia os deuses dos mortais.
\end{abstract}

Nos versos acima, a imponência da Grécia e de sua cultura na poesia de Sophia é expressa pela vitalidade com que o cenário pelo qual passa Dionysos é descrito. Naquela ocasião, o céu do fim de tarde - sugerido no terceiro verso da primeira estrofe - é reiterado tanto pelo "vermelho" que arde, quanto pela plenitude da "perfeição vermelha". Desse modo, tais versos contêm glória e exaltação de um deus grego e da superioridade dele diante dos mortais.

A manifestação do divino no mundo natural, aliás, exemplifica, novamente a memória de tudo aquilo que o sujeito poético almeja, simbolizando o regresso a um tempo mítico de pureza e de perfeição marcado pela harmonia e pela completude. Exemplo disso é o poema "Marinheiro real" (Mar Novo), no qual a imagem divina surge como paradigma de inteireza:

\author{
Vem do mar azul o marinheiro \\ Vem tranquilo ritmado inteiro \\ Perfeito como um deus, \\ Alheio às ruas
}

Essa mesma comunhão que se estabelece com os deuses, segundo Antônio Manuel dos Santos Cunha (2004, p.94), também se manifesta em relação ao original, ao que repousa naquilo que está no princípio de tudo, conforme é possível observar no poema "O primeiro homem" (Dia do Mar), no qual desde o título, tem-se a imagem de algo que é da ordem do primordial relacionado à origem, num contexto que alude ao começo da trajetória humana:

Era como uma árvore da terra nascida Confundindo com o ardor da terra a sua vida E no vasto cantar das marés cheias Continuava o bater das suas veias.

Nos poemas mencionados acima, aquilo que é da ordem do humano se funde com o que habita a esfera do natural, de modo que terra, árvore, mar e 
homem já não têm mais fronteiras, não se sabe onde terminam as marés e onde começa o bater das veias.

Símbolo de uma felicidade irrecusável, a exaltação do divino, segundo António Manuel dos Santos Cunha, em um determinado momento da obra da poeta, ganha nuances sombrias, à medida em que o sujeito poético parece darse conta de que a comunhão com os deuses tão almejada não mais se dará:

Efectivamente, a partir de No tempo dividido, o Poeta parece tomar consciência da triste ausência daqueles ideais protagonizados pelos deuses ('A liberdade que dos deuses eu esperava / Quebrou-se') e com ela o fim de uma aliança que Ihe permitiria recuperar ' $O$ estar-ser-inteiro inicial das coisas' exaltado no poema 'Os gregos' do livro Dual (CUNHA, 2004, p. 95-96).

Exemplo dessa nova condição do eu, o poema "No tempo dividido" alude a essa separação do mundo dos deuses. Nos versos que seguem é possível identificar claramente a ideia de ruptura. O poema já começa com a consequência dessa divisão, na medida em que o sujeito poético se desconhece:

\footnotetext{
E agora ó Deuses que vos direi de mim?

Tardes inertes morrem no jardim.

Esqueci-me de vós e sem memória

Caminho nos caminhos onde o tempo

Como um monstro a si próprio se devora.
}

Observa-se que, ao dar-se conta de que se esqueceu dos deuses, o sujeito perde completamente o seu rumo. Mais que isso, seu mundo parece fadado à ruína, ao desaparecimento, pois mais do que a distância temporal dos deuses do passado, o eu vive o drama do esquecimento. Pior que a distância temporal frente a um passado saudoso é o completo apagar-se de sua memória.

É nesse momento que a perspectiva da cisão entre sujeito poético e os deuses toma forma. Ao refletir sobre o poema "Exílio" (O nome das coisas), que se resume em um dístico, é possível observar claramente como o ser torna-se incompleto quando rompe com os deuses. O verso inicial, aliás, sugere que tal afastamento é de responsabilidade do próprio homem: "Exilamos os deuses e fomos / Exilados na nossa inteireza". 
Diante da irremediável impossibilidade de comunhão com o que é da ordem do divino, o sujeito poético sai em busca de uma alternativa possível que o aproxime desse espaço almejado, seja pela via da memória de um mundo perdido, de um reino puro e límpido, seja pela configuração da poesia como um elo, uma ponte entre o real e o primordial.

No que tange ao tom saudosista diante da herança mítica, Fernando Pinto do Amaral observa como essa postura se manifesta por meio da imagem da volta, do retorno a um tempo "primordial" e "incorruptível" no qual poderão "coexistir homens e deuses tão naturalmente como na Grécia da infância do mundo" (AMARAL, 1999, p. 7).

António Manuel dos Santos Cunha também defende que, mesmo habitando o mundo dos homens, "ainda é possível resgatar um pouco da sua presença na Grécia, 'país da imanência sem mácula"” (2004, p. 132).

Essa luta por resgatar o elo desfeito com o primordial tem na palavra uma expressão possível. Nos poemas da autora, tal característica se faz presente na ideia da busca pela unidade, que "não é só a perfeição das coisas, mas também o sonho de encontrar um país sem mal" (CEIA, 1996, p.62).

Tomando como referência o livro Ilhas, Carlos Ceia sinaliza que a itha afortunada será sempre a visão de algo efêmero, de um sonho que nunca vai se realizar. Conforme observa a própria Sophia, em entrevista a Antônio Guerreiro:

\footnotetext{
Essa impossibilidade de que fala um dos meus poemas de encontrar o país sem mal tem a ver com este último livro. As ilhas são, neste caso, os momentos e lugares que foram como ilhas no meio da confusão. Esse caminhar errante em busca de ilhas e mundos novos e desconhecidos é uma característica indissociável da metáfora da navegação, uma forma de recuperar o espírito pan-helênico de Delfos (CEIA, p.62-63).
}

Não por acaso, a poesia surge na obra da autora como "ilhas no meio da confusão". Fuga do caos e do tumulto do mundo, o fazer poético é o espaço no qual a dualidade imanente do real surge como uma manifestação natural, como algo que está presente na realidade espontaneamente, sem a necessidade de nenhum estímulo externo. De modo que a verdade do real 
apresenta-se ancorada no próprio discurso poético da autora para quem as palavras são, por natureza, dotadas de uma justiça imanente. Nesse sentido, a poesia surge como o elo que novamente aproxima o homem do tempo primordial tão almejado, conforme observa Helena Carvalhão Buescu:

E isto faz da poesia, nas palavras de Sophia, 'uma moral' intrínseca, não uma procura de uma justiça exterior que viesse eventualmente somar-se ao dizer poético, mas o descobrimento e a manifestação de que é na própria 'respiração das palavras' que a justiça do mundo também vive, decorrendo, ou talvez mesmo melhor - correndo naturalmente da 'felicidade irrecusável' e do 'esplendor' do real (BUESCU, 2005, p.54).

Dessa luta pela plenitude, a poesia emerge de uma busca sem trégua, fruto do rigor que parte daquilo que é árido e sofrido. Se, ao encontro do que já foi dito anteriormente, o poeta tem que atravessar percalços tortuosos para alcançar a esfera tão almejada, a consciência tão arguta do seu dever acaba por impeli-lo a descobrir a verdade do real, a desvendá-lo em todas as suas vicissitudes e ângulos, de modo que, da busca pelo todo, ele acaba descobrindo a dualidade imanente que habita a realidade:

Sendo que 'A poesia busca o verdadeiro estar do homem na terra', cabe ao Poeta intervir sobre o real e trazer à luz o que há de mais sombrio para o dizer, como se lê no poema em análise, 'na lisura dos pátios do quadrado / de sol de nudez e de confronto', num exercício de intenso rigor, porque o poema nasce, conforme a própria autora refere em 'Arte poética II' de uma 'obstinação sem tréguas' e de um 'obstinado rigor' (CUNHA, 2004, p.62).

E é dessa maneira que a poesia se apresenta como uma forma de transgressão para Sophia: "O poema é liberdade" ("Liberdade", O nome das coisas), é uma maneira de burlar a irremediável condição precária de uma realidade na qual predominam a cisão e a desordem que tanto incomodam o sujeito poético:

É através da escrita que Sophia luta contra o caos e procura restabelecer a ordem há muito perdida, reconquistando a consciência original, sempre 'Em busca do país sem mal' (CUNHA, 2004, p.143). 
Essa transgressão, ao mesmo tempo que sugere revolta e a necessidade de ir contra uma ordem imposta, não implica necessariamente algum tipo de contravenção. Muito pelo contrário, a transgressão em Sophia apresenta-se como algo natural, espontâneo e inerente à vida e imanente na natureza e naquilo que o poeta, em sua perseguição do real, quer recomeçar, desvendar:

\author{
Revolução isto é: descobrimento \\ Mundo recomeçado a partir da praia pura \\ Como poema a partir da página em branco \\ - Catarsis a emergir verdade exposta \\ Tempo terrestre a perguntar seu rosto
}

Não por acaso, muitas vezes é possível observar na obra da autora que a origem do primordial, daquele tempo/espaço tão almejado pelo sujeito poético, está presente nos elementos que remetem à infância e a um tempo regenerador fundado na ideia de completude:

\begin{abstract}
A infância, pela rica diversidade que comporta, é o tempo da totalidade informe e, por isso mesmo, o ponto de partida para o sujeito poético desfiar os fios do novelo que o conduzirão ao interior de si mesmo. Trata-se de um retorno às origens, não como uma espécie de paraíso perdido, mas como um tempo pleno de vitalidade que perdura e actua no presente, dotandoo de uma energia primordial (CUNHA, 2004, p.71-72).
\end{abstract}

Nutrindo-se das reminiscências desse tempo de plenitude, o sujeito articula suas ações: "O Poeta procura libertar-se das amarras do presente e projetar-se num futuro construído à margem de um passado mítico" (CUNHA, 2004, p.83).

Tomando como mote o antagonismo que pressupõe a relação entre presente e passado na obra da poeta, convém reforçar que a busca pela unidade primordial do ser está diretamente ligada à consciência arguta do real. A inteireza de um indivíduo só existe face à noção da verdade e é nesse sentido que a poesia revela mais uma de suas propriedades, a de tirar o ser da alienação, conforme observa a poeta em um texto lido no "I Congresso de 
Escritores Portugueses", realizado em 1975, e publicado na obra 0 nome das Coisas ${ }^{5}$ :

É a poesia que me implica, que me faz ser no estar e me faz estar no ser. É a poesia que torna inteiro o meu estar na terra. E porque é a mais funda implicação do homem no real, a poesia é necessariamente política e fundamento da política.

[...]

E porque busca a inteireza, a poesia é, por sua natureza, desalienação, princípio de desalienação, desalienação primordial. Liberdade primordial, justiça primordial (ANDRESEN, 1977, p.7).

Sendo o poeta um indivíduo impelido a extrair a verdade por meio do poema, ao escrever, esse arquiteto das palavras constrói uma ponte que religa aquilo que a realidade em seu caos imanente separa. Mais do que "religar o homem a uma ordem primordial perdida", esse ofício é, pois, fonte da verdade.

A missão do poeta é pois transpor o mundo do real para 'o mundo do poema limpo e rigoroso', a fim de fazer aparecer a mais funda verdade que o habita e nele guardar o 'intenso fogo devorador das coisas / Que sempre esteve muito longe e muito perto' (CUNHA, 2004, p.34).

\footnotetext{
${ }^{5}$ A edição da obra onde o discurso foi publicado data de 1977, tratando-se, desse modo, de uma edição diferente daquela editada pela Editorial Caminho, de 2004, considerada no processo de seleção para a análise do Corpus.
} 


\section{O espaço natural e a identidade do sujeito}

A configuração que o espaço natural assume na poética de Sophia de Mello Breyner Andresen é um dos temas pontuais do presente trabalho. Ao trazer à tona a leitura deste ambiente como lugar de plenitude e realização para o sujeito poético, este estudo antecipa elementos que serão discutidos no capítulo quarto, no qual se estabelece um contraponto entre o meio natural representado na imagem do mar principalmente e o espaço urbano. Se no espaço modelado pela mão do homem este indivíduo aparece como um ser desterrado a vagar por um universo corrompido, o ambiente natural, por sua vez, é o lugar onde ele encontra sua própria identidade.

Comumente ligado à imagem daquilo que é primordial, o espaço natural na poesia da autora surge muitas vezes associado à ideia de plenitude e realização, vale lembrar que não se trata de uma idealização do real, mas de uma busca pelos resquícios do primordial que habita o homem:

[...] só pela união com as coisas mais límpidas e puras da natureza será possível ter acesso à vida verdadeira. Este naturalismo primário exige pelo menos uma ressalva: por regra, Sophia é infensa a qualquer idealização da realidade e insiste particularmente nos aspectos que, no homem, resultam da natureza e de suas leis, mas a redução destas leis do mundo concreto material são constantemente atravessadas pela intervenção de causas transcendentes, como os desejos de espiritualização e de imortalidade comprovam. Seria, pois, mais adequado falar de um naturalismo elemental que preconiza a volta à natureza e à simplicidade primitiva sobretudo na maneira de viver, sem excluir a presença inquietantemente estranha do divino na forma de expressão desse viver (CEIA, 1996, p. 152-153).

No poema "Habitação", publicado na obra Ilhas (1989), o ambiente natural aparece de forma velada, remetendo ao primordial e a tudo que existia no mundo no início. Tanto é que, para reforçar a configuração deste meio como o espaço inicial, o sujeito poético lista diferentes tipos de habitações, desde a campestre, como o chalé, até suntuosas moradas, como palácios e castelos. É interessante ainda observar que a alusão ao espaço da plenitude inicial está atrelada à ideia de um tempo remoto de comunhão não apenas entre os homens, mas destes com os mortos e com os deuses. 


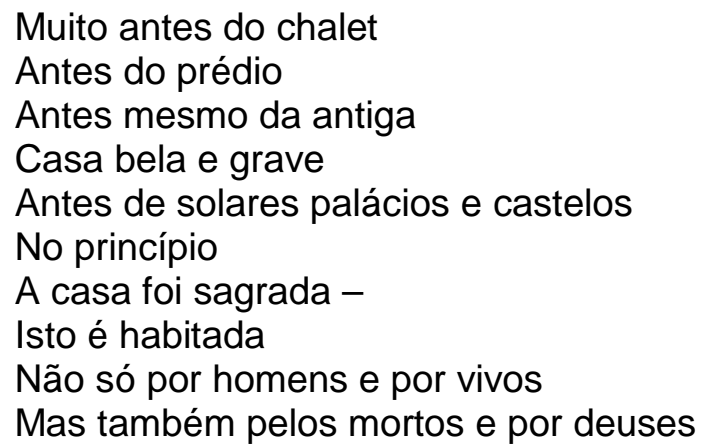

Nesse mesmo poema, é possível identificar mais adiante a relação antitética que o meio estabelece com o espaço modelado pela mão humana, na medida em que o sujeito revela que a situação inicial de comunhão entre o homem, o espaço natural e os deuses fora abalada. Essa nova realidade surge aos olhos do indivíduo como uma imposição violenta que não apenas impõe ao seu universo uma nova ordem como também provoca uma cisão em seu meio. A paisagem inicial fora reconfigurada e a intervenção humana é evidente, conforme é possível observar nos versos abaixo:

Isto depois foi saqueado

Tudo foi renovado e dividido

Caminhamos no trilho

De elaboradas percas

Quanto a esses versos, convém observar ainda que, ao ter seu reino dividido, o indivíduo, consequentemente, surge como um homem perdido. No entanto, na última estância do poema, a redenção se dá por meio da poesia, que surge como uma forma de restabelecer o elo perdido. Se na casa sagrada tudo que era da ordem do primordial se foi, a poesia - que a tudo resiste surge não apenas como uma espécie de memória, mas principalmente como permanência de um tempo em que ainda era ouvido o "sussurrar das tílias". Mais do que lembrança de uma época remota, ela é o lugar da preservação por excelência.

Porém a poesia permanece

Como se a divisão não tivesse acontecido

Permanece mesmo muito depois de varrido

O sussurro de tílias junto à casa de infância 
Não por acaso, aquele que se dedica ao ofício da poesia é descrito por Schopenhauer como um indivíduo que, de alguma forma, mantém com a realidade uma relação semelhante àquela que o natural mantém com 0 universo. Trata-se de um ser que realça a vida em todas as suas implicações mais latentes, tornando perceptível aquilo que os outros não vêem, retendo aquilo que é efêmero por natureza. Segundo Schopenhauer,

O poeta é, portanto, o resumo do homem em geral: tudo o que alguma vez fez bater o coração de um homem, tudo o que a natureza humana, numa circunstância qualquer, fez brotar para fora de si, tudo o que alguma vez brotou e amadureceu num peito humano, tal é a matéria que ele trabalha, como trabalha todo o resto da natureza [...] Ele é o espelho da humanidade, e coloca-lhe na frente dos olhos todos os sentimentos de que ela está cheia e animada (SCHOPENHAUER, 2001, p.262).

Considerando, ainda, a relação entre o espaço natural e o primordial, convém observar o trecho abaixo, extraído do poema "Primeira liberdade", publicado na obra No tempo Dividido (1954). Nesta passagem, a memória deste tempo inicial é evocada por elementos que aludem a coisas impalpáveis. Ora uma sensação, ora uma visão efêmera, tudo remete a algo que ficou perdido no tempo.

Eu falo da primeira liberdade

Do primeiro dia que era mar e luz

Dansa, brisa, ramagens e segredos

No poema em questão, os elementos água (mar), fogo (luz), ar (brisa) e terra (ramagens) aparecem sempre associados a uma ideia de algo imaculado, inicial. A "primeira liberdade" mencionada no verso de abertura do poema já anuncia esse tema que irá percorrer todos os versos. É pertinente observar como essa configuração daquilo que é inicial, imaculado e puro compõe a paisagem. "Mar", "brisa, "ramagens", tudo faz parte de um espaço ainda livre da intervenção humana. Ao encontro dessa perspectiva, Carlos Ceia chama a atenção para a trajetória de tais elementos na poesia de Sophia de Mello Breyner Andresen, a começar pelo mar, cuja simbologia está sempre muito próxima da ideia de liberdade: 
A liberdade de navegação que podemos ler nos poemas de Sophia inscreve-se nesta tradição antiga e pode dizer respeito tanto à liberdade no mar como ao mar como metáfora da liberdade [...] (CEIA, 1996, p. 61).

Na mesma linha, o vento remete à noção de equilíbrio e encontro do sujeito consigo mesmo:

Nas tradições avésticas da antiga Pérsia, 0 vento desempenhou o papel de suporte do mundo e governante de todos os equilíbrios cósmicos e espirituais, onde o poeta pode naturalmente procurar seu próprio equilíbrio, recuperando o seu lugar no mundo (CEIA, 1996, p.44).

A luz, por sua vez, no mundo de Sophia aparece como uma referência religiosa, simbolizando a crença no Cristo

[...] a luz dos homens será entendida como a luz do mundo criado por Deus. E a luz do mundo será também a luz da realização do Ser, que é indivisível e constitui a busca suprema (CEIA, 1996, p. 88).

Por fim, os versos finais do poema falam de algo novo e intacto, mas que fora perdido precocemente - "E um primeiro amor morto tão cedo". Entretanto, nem mesmo a morte calou esse sentimento, que se renova "Que em tudo que era vivo se encarnava."

A busca pelo primordial também está presente no poema "Inicial", publicado na obra Dual (1972). O elemento mar desta vez é destacado por sua brancura, pelo constante 'lavar e relavar' das coisas e pela imagem da concha regressada, num contexto em que esse conjunto traz à tona a permanente transformação e o eterno renovar daquilo que compõe o real:

O mar azul e branco e as luzidias

Pedras - $O$ arfado espaço

Onde o que está lavado se relava

Para o rito do espanto e do começo

Onde sou a mim mesma devolvida

Em sal espuma e concha regressada

À praia inicial da minha vida 
"Símbolo da dinâmica da vida" (Chevelier e Gheerbrant, 2007), o mar é o lugar onde o inicial se configura. Mas, dada sua natureza instável, ele também é o espaço onde as transformações, mudanças e, principalmente as renovações acontecem, como é o caso do poema em questão. A imagem em movimento do "arfado espaço / Onde o que está lavado se relava / Para o rito do espanto e do começo" vai justamente ao encontro da leitura do espaço marítimo apresentada por Chevelier e Gheerbrant, na qual a transitoriedade desse ambiente surge como uma de suas características primordiais: "Tudo sai do mar e tudo retorna a ele: lugar dos nascimentos, das transformações e dos renascimentos" (Chevelier e Gheerbrant, 2007, p.592).

Neste momento, é interessante chamar a atenção para a leitura que Deleuze e Guattari fazem do ambiente marítimo a partir do que os autores denominam "espaços lisos", que, segundo eles, são ocupados pelas intensidades, pelos ventos e ruídos, pelas forças e pelas qualidades tácteis e sonoras, como é o caso do deserto, da estepe e do gelo. Ligado à ideia de variação contínua e desenvolvimento permanente da forma, o liso vai ao encontro da leitura feita pelo sujeito poético acerca do mar, lugar onde "tudo que está lavado se relava / para o rito do espanto e do começo". Essa percepção dialoga diretamente com o pensamento do liso como um espaço onde tudo se desenvolve de forma contínua, numa intensa harmonia que repousa no ir e vir das ondas:

Para voltar à oposição simples, o estriado é o que entrecruza fixos e variáveis, ordena-se e faz suceder formas distintas, organiza as linhas melódicas horizontais e os planos harmônicos verticais. O liso é variação contínua, é o desenvolvimento contínuo da forma, é a fusão da harmonia e da melodia em favor de um desprendimento de valores propriamente rítmicos, o puro traçado de uma diagonal através da vertical e da horizontal (DELEUZE e GUATTARI, 2008, p. 184).

Outro aspecto observado no presente poema revela-se com mais intensidade no segundo verso, no qual o emprego do verbo arfar na forma adjetivada confere ao espaço marítimo uma característica que o aproxima de um ser vivente: a respiração. Mais que isso, a expressão "arfado espaço" sugere uma ideia de novo fôlego, é como se, do mar, todas as coisas 
conseguissem extrair fôlego para um novo começo, que surge associado a um ritual de purificação: "Onde o que está lavado se relava / Para o rito do espanto e do começo".

$\mathrm{Na}$ medida em que o mar surge como espaço de renascimento para o sujeito poético, é nele que o sujeito se reconhece e se identifica. Como um ser errante, lá ele finalmente encontra seu verdadeiro "eu", um "eu" já purificado e em completa comunhão com o natural: "Onde sou a mim mesma devolvida / Em sal espuma e concha regressada / À praia inicial da minha vida".

Esse conceito de renascimento persiste em outro poema publicado em Dual: "A fonte". Nele também é possível fazer uma leitura do espaço natural como um ambiente de renascimento, conforme a própria simbologia desse elemento já sugere: "Em virtude de suas águas sempre cambiantes, a fonte simboliza, não a imortalidade, mas sim um perpétuo rejuvenescimento" (CHEVALIER E GHEERBRANT, 2007, p.444).

Estes versos do referido poema:

\author{
Com voz nascente a fonte nos convida \\ A renascermos incessantemente \\ $\mathrm{Na}$ luz do antigo sol nu e recente \\ E no sussurro da noite primitiva
}

tematizam a ideia de regeneração e purificação, apresentando a fonte como símbolo perfeito desse processo. É interessante salientar que tal perspectiva de eterna renovação - "Com voz nascente a fonte nos convida / A renascermos incessantemente" - está curiosamente associada ao elo com o passado em sua essência mais primitiva, remetendo à pureza das coisas em seu estado inicial: "Na luz do antigo sol nu e recente / E no sussurro da noite primitiva."

Já em "Oásis", publicado em $O$ nome das Coisas (1977), o sujeito parte da descrição desse ambiente para realçar o meio natural como conjuntura primordial, original. Esse, por sua vez, ao apresentar-se como um meio livre de qualquer mácula, surge como o derradeiro espaço onde o homem poderá se purificar e buscar a redenção.

Penetramos no palmar

A água está clara o leite doce

O calor está leve o linho branco e fresco

O silêncio estará nu - o canto 
Da flauta será nítido no liso

Da penumbra

Lavaremos nossas mãos de desencontro e poeira

Nesse poema, é interessante observar também as sinestesias que revelam a percepção que o sujeito tem do real. Ao mesmo tempo que a claridade da água e a brancura do linho podem ser interpretadas como alusão à visão, a imagem poética da doçura do leite remete a uma mescla de paladar e visão; já o canto da flauta surge não só como uma manifestação desse espaço primordial através da audição, como também por meio da percepção táctil, na medida em que ele "será nítido no liso / Da penumbra". Tomando como ponto de partida o conceito de Deleuze e Guattari acerca do espaço liso, é interessante observar como os elementos sinestésicos presentes no poema se aproximam das sensações e percepções sensoriais que configuram o liso, conjuntura na qual a sensibilidade táctil e sonora se sobressai.

Eis que diante desse cenário imaculado o sujeito poético, egresso do espaço regido pelo homem, espera se purificar. $O$ emprego do futuro do presente no verso final projeta um tempo futuro almejado pelo "eu" e o apagamento do passado de tristezas e decepções: "lavaremos nossas mãos de desencontro e poeira". Essa mesma característica reaparece na obra Dia do Mar, publicada em 1947, no poema "Um dia", que tem como tema central a figura de um sujeito poético que mais uma vez busca aproximar-se da plenitude que habita aquilo que compõe o espaço natural.

Um dia, mortos, voltaremos

A viver livres como os animais

E mesmo tão cansados floriremos

Irmãos vivos do mar e dos pinhais.

O vento levará os mil cansaços

Dos gestos agitados irreais

$E$ há-de voltar aos nossos membros lassos

A leve rapidez dos animais.

Só então poderemos caminhar Através do mistério que se embala No verde dos pinhais na voz do mar E em nós germinará a sua fala. 
Chave de leitura do texto poético, o título - "Um dia" - sugere a espera por um tempo futuro, numa imagem que carrega o aguardar por uma espécie de redenção que perpassa todo o poema. Já no verso inicial, a morte surge com um viés libertador, na medida em que é apresentada como uma forma de restabelecer o elo perdido com o primordial.

Nesse texto poético, é possível observar que a identificação do sujeito com o espaço natural é tão plena que aos poucos ele vai se tornando parte do meio. Se, nos versos iniciais da primeira estrofe ele se aproxima do meio animal pela via da comparação - "Um dia, mortos, voltaremos / A viver livres como os animais" -, no terceiro, essa identificação com o meio natural surge com mais ênfase pela perspectiva metafórica do desabrochar de um novo eu, mais pleno, mais belo: "E mesmo tão cansados floriremos". Essa sintonia entre meio e sujeito poético persiste no verso final da estrofe, quando fica nas entrelinhas um tom fraternal em relação ao meio natural: "Irmãos vivos do mar e dos pinhais".

Na segunda estância, logo no primeiro verso, a figura do vento surge associada à ideia de mudança. "Portador de mensagens" (CHEVELIER E GHEERBRANT, 2007, p.936), é ele que se encarrega de livrar o sujeito das angústias do espaço configurado pelo homem. Neste lugar, repousam sob a imagem dos "mil cansaços", o peso, os vícios e o esgotamento acarretado pelo excesso desmedido. Nos dois versos finais da segunda estrofe, a presença do vento como símbolo da redenção é salientada, na medida em que o sujeito espera romper com esse estado de exaustão através da leveza: "E há-de voltar aos nossos membros lassos / A leve rapidez dos animais".

A estrofe final, enfim, arremata essa busca essencial do sujeito poético em resgatar o primordial em toda a sua pureza, leveza e vitalidade. Em seu retorno onírico, o sujeito poético, uma vez livre do peso e do cansaço que rege sua existência no espaço transformado pelo homem, poderá se embrenhar pelo desconhecido. Nessa comunhão tão intensa perde-se referência de onde termina o sujeito e onde começa o espaço natural, que acaba por se revelar uma extensão do ser, o qual por meio do ambiente natural se expressa: "Só então poderemos caminhar / Através do mistério que se embala / No verde dos pinhais na voz do mar / E em nós germinará a sua fala." 
O poema "Meio Dia", publicado em Poesia (1944), livro de estreia da autora, também expressa bem a aproximação entre o meio natural e a representação do espaço liso. No primeiro verso, projeta-se uma imagem do espaço desértico como sítio ideal para uma espécie de celebração do meio natural.

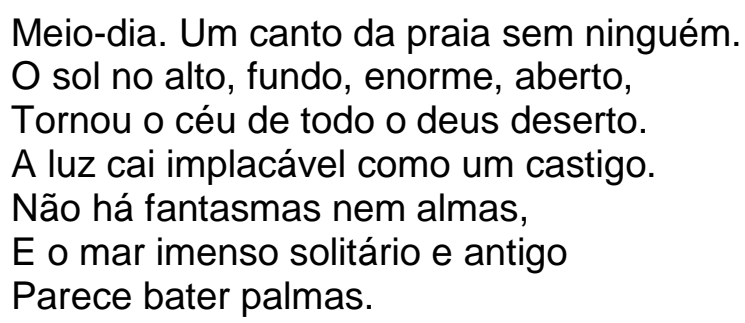

A leitura do poema projeta o leitor para a visão de uma tela de pintura: "O sol no alto, fundo, enorme, aberto, / Tornou o céu de todo o deus deserto." Além do forte teor pictórico desses versos, é interessante observar a presença dominante do sol, reforçada por adjetivos como "alto", "fundo", "enorme", "aberto", enfim, termos que remetem à grandiosidade de um astro que supera até mesmo os deuses. Não por acaso, aos olhos do "eu" poético, a luz que do sol emana "cai implacável como um castigo" ao mesmo tempo que o astro rei prossegue reinando sobre tudo: "Não há fantasmas nem almas". É diante deste quadro que o mar em sua vastidão inerente completa esta cena, numa espécie de epifania coletiva do ambiente natural: "[...] imenso solitário e antigo / parece bater palmas."

Outra presença constante na obra da poeta é o jardim, mais um espaço que pode ser definido como liso e através do qual o sujeito busca a comunhão com o natural. Símbolo do paraíso terrestre, esse ambiente é, segundo Chevelier e Gheerbrant, centro do cosmo e representação das vivências paradisíacas:

Sabe-se que o paraíso terrestre do Gênesis era um jardim, sabe-se que Adão cultivava o jardim; o que corresponde à predominância do reino vegetal no começo de uma era cíclica, enquanto a Jerusalém celeste do fim será uma cidade (CHEVALIER e GHEERBRANT, 2007, p.512). 
Francisco Bethencourt (1991), na mesma linha, chama a atenção para um tempo remoto em que o homem vivia em equilíbrio com o meio natural:

O jardim é, como já insinuamos, um símbolo do paraíso terrestre, dominado pelo reino vegetal, onde os primeiros homens viviam em harmonia com a natureza (Francisco Bethencourt, 1991, p.113).

Não por acaso, esse ambiente surge ora como um dos espaços almejados pelo sujeito poético ora como travessia necessária para se chegar a esse derradeiro destino. Em "O jardim e a noite" (Poesia, 1944), o jardim está diretamente ligado à transposição de um obstáculo. Já na estrofe inicial é possível observar que, para alcançar a comunhão com a noite, objeto de desejo do "eu", é preciso enfrentar a solidão e a escuridão que habitam o jardim. Nessa mesma estância, o advérbio "outrora", presente no terceiro verso, permite que se leia nas entrelinhas que essa união entre as almas do sujeito e da noite solitária já existiu num tempo remoto:

\footnotetext{
Atravessei o jardim solitário e sem lua, Correndo ao vento pelos caminhos fora, Para tentar como outrora Unir a minha alma à tua, Ó grande noite solitária e sonhadora. $[\ldots]$
}

A mesma perspectiva do acesso ao jardim associada à ideia de uma travessia difícil pode ser lida na relação que Yvette Centeno constrói a partir da definição junguiana desse espaço como o símbolo do Eu Superior cujos "portões é preciso saber atravessar":

Para Jung o Jardim é um símbolo do Em-Si, do Eu Superior (Selbst) e a fonte, que muitas vezes é representada no seu centro, a própria água da vida. Água ou Árvore, o símbolo terá neste caso a mesma interpretação. É o que vemos nos jardins dos alquimistas, nos seus roseirais guardados por portões que é preciso saber atravessar (CENTENO, 1991, p.208).

$\mathrm{Na}$ estrofe seguinte, ainda à mercê dos temores que essa travessia desperta, o sujeito imagina o acordar de um sono, trazendo à tona a figura da encantação, capaz de ressuscitar sonhos, no passado, sepultados. 
Entre os canteiros cercados de buxo,

Sorri à sombra tremendo de medo.

De joelhos na terra abri o repuxo,

E os meus gestos foram gestos de bruxedo.

Foram os gestos dessa encantação,

Que devia acordar do seu inquieto sono

A terra negra dos canteiros

E os meus sonhos sepultados

Vivos e inteiros.

$[\ldots]$

A estrofe acima também apresenta uma espécie de viagem onírica durante a qual o sujeito faz emergir todos os seus anseios e sonhos do passado. É interessante observar a imagem que se forma a partir da oposição entre vida e morte nos dois últimos versos da estância. Nota-se que os sonhos, apesar de enterrados, ainda pulsavam sob a terra, denunciando que, a despeito da realidade aparentemente estável, o desejo desse indivíduo de despertar e transgredir o real permanece. Considerando a leitura que Maria Helena da Rocha Pereira faz do jardim, observa-se também nos versos acima a busca por algo inalcançável: "Tudo que é divino é longínquo, inacessível; por isso, o jardim tem de ficar além dos limites do mundo conhecido [...]"

Entretanto, a estância seguinte mostra que esse anseio do sujeito poético permanece malogrado:

Mas sob o peso dos narcisos floridos
Calou-se a terra,
E sob o peso dos frutos ressequidos
Do presente,
calaram-se os meus sonhos perdidos.

Nesse sentido, é interessante chamar a atenção para a simbologia que está por trás da figura dos narcisos. Comumente plantados sobre os túmulos, essas flores, segundo Chevalier e Gheerbrant "simbolizam o entorpecimento da morte, mas uma morte que não é talvez senão um sono" (2007, p.629).

É esse entorpecimento que parece reger o jardim que o sujeito atravessa. E ainda que ele clame por reviver os sonhos sepultados no passado, a firmeza dos narcisos enraizados na terra sugere a presença incisiva de um real regido pela morte. Nesse contexto, o outro sentido possível evocado pela simbologia do narciso - o de renascimento (p. 630) - também cai por terra. Tanto é que nos dos versos seguintes, a imagem dos frutos ressequidos 
corroboram a interpretação de que, no presente, os sonhos desse indivíduo estão fadados à frustração.

Outro aspecto que chama a atenção na leitura dessa composição é a associação que se estabelece entre tudo o que é da ordem do espaço natural e a palavra. Da mesma forma que a vegetação e a água, em sua pureza e limpidez, remetem à vida em toda a sua espontaneidade, a escrita daquele tempo remoto -"outrora" -, segundo o sujeito poético, é o gesto "dum impulso" em sua forma primitiva e pura, sugerindo também a mesma ideia de espontaneidade:
Entre os canteiros cercados de buxo,
Enquanto subia e caía a água do repuxo, Murmurei as palavras em que outrora Para mim sempre existia
O gesto dum impulso.
Palavras que eu despi da sua literatura, Para lhes dar a sua forma primitiva e pura, De fórmulas de magia.

Nota-se que através do meio natural e das palavras de encantamento de um tempo remoto, primitivo, o sujeito busca reavivar o passado onírico que fora sepultado, e o faz pela via da magia. No entanto, os anseios do sujeito são vãos, haja vista que a noite permanece inatingível e o "eu" revela ter ciência disso, quando admite que sua ânsia é "carregada de impossível":

\footnotetext{
Docemente a sonhar entre a folhagem

A noite solitária e pura

Continuou distante e intangível

Sem me deixar penetrar no seu segredo.

E eu senti quebrar-se, cair desfeita, A minha ânsia carregada de impossível Contra a sua harmonia perfeita.
}

Nas duas estrofes finais, nota-se que, apesar de o meio colaborar para a comunhão tão almejada pelo sujeito, já é tarde para reviver os sonhos do passado. É como se aquele tempo remoto fosse impenetrável no presente, numa espécie de celebração do meio natural da qual o homem não pode participar. 
Tomei nas minhas mãos a sombra escura

E embalei o silêncio nos meus ombros.

Tudo em minha volta estava vivo

Mas nada pôde acordar dos seus escombros

O meu grande êxtase perdido.

Só o vento passou pesado e quente

E à sua volta todo o jardim cantou

E a água do tanque tremendo

Se maravilhou

Em círculos, longamente.

Em outro poema da autora, "Jardim do Mar", publicado na obra Dia do Mar (1947), tem-se uma imagem que se distancia tanto da ideia do paraíso terrestre, quanto do conceito de travessia difícil, na medida em que traz à tona a imagem de um jardim que o tempo todo rivaliza com o mar. É interessante atentar para a referência à cidade conhecida como a antítese de Jerusalém Babilônia -, que surge já na primeira estrofe, na menção ao jardim suspenso:

\section{Vi um jardim que se desenrolava \\ Ao longo de uma encosta suspenso \\ Milagrosamente sobre o mar \\ Que do largo contra ele cavalgava \\ desconhecido e imenso.}

Essa relação antagônica entre mar e jardim que perpassa a primeira estância é ressaltada pelo emprego do verbo "contra", que sugere, já de início, uma relação antitética entre dois elementos: terra (jardim) e água (mar).

Símbolo do paraíso, o jardim, neste poema, tem sua leitura original modificada. A imagem do Éden cede espaço a uma representação obscura daquilo que antes evocava a ideia de natureza original. Agora, as feições são outras, num contexto em que todas as imagens remetem à aridez deste espaço ornado por uma flora selvagem e agreste:

\footnotetext{
Jardim de flores selvagens e duras

E cactos torcidos em mil dobras,

Caminhos de areia branca e estreitos

Entre rochas escuras

$[\ldots]$
}

Nesse cenário do paraíso invertido, a aspereza e a dureza tomam conta da cena, num contexto em que o jardim paradisíaco surge devastado. Ao 
mesmo tempo, aquilo que é da ordem do mar passa a configurar o jardim, conforme é possível observar na passagem abaixo:

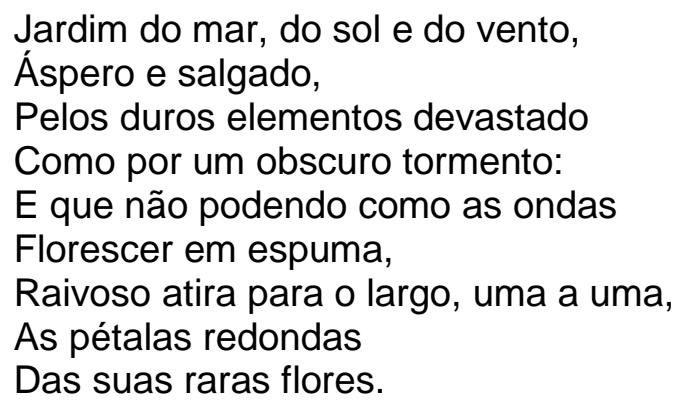

No trecho acima, assim como em boa parte da obra de Sophia, a presença das imagens é muito marcante. Os quatro elementos já se apresentam logo no primeiro verso da estrofe. "Jardim", "mar", "sol" e "vento" são as representações de terra, água, fogo e ar, respectivamente. É interessante observar como dois desses elementos se destacam entre os demais e fazem um movimento de deslocamento, a começar pelo título do poema que, no caso, abre a estrofe em questão. "Jardim do mar" antecipa a ideia de que o primeiro está contido no segundo. O jardim, "áspero e salgado" (adjetivo inerente ao mar) fora devastado por um "obscuro tormento" (termo típico do vocabulário marinho). Entretanto, a presença desse poderio do mar aparece de forma mais incisiva alguns versos depois - "florescer em espuma" , quando às ondas do mar é dado um poder que somente ao jardim fora cedido até então: o de florescer. $E$ eis que diante dessa cena, o jardim, antes morada paradisíaca onde as flores germinam, torna-se o próprio algoz de suas obrasprimas, desfolhando-as: "Raivoso atira para o largo, uma a uma, / As pétalas redondas / Das suas raras flores."

$\mathrm{Na}$ estrofe seguinte, a soberania do elemento água frente ao elemento terra se intensifica. Observa-se que o mar - assim como a figura da sereia, que encanta os pescadores para atraí-los para a morte - exerce o mesmo fascínio sobre o jardim. O poder que o elemento marítimo detém é uma constante. A própria referência a algo esplendoroso no poema surge como uma característica intermitente, na medida em que tal magnificência se renova a cada hora, como revelam os dois versos finais da estrofe: 
Jardim que a água chama e devora

Exausto pelos mil esplendores

De que o mar se reveste em cada hora.

A estância final, mais uma vez, reforça a inversão de papéis que perpassa o poema desde seu primeiro verso. $O$ jardim não detém domínio sobre nada, prevalece o poder do mar. A soberania do espaço marítimo chega ao ponto de, no segundo verso da estrofe, o sujeito poético atribuir-lhe um membro humano - a mão:

\author{
Jardim onde o vento batalha \\ E que a mão do mar esculpe e talha. \\ $\mathrm{Nu}$, áspero, devastado, \\ Numa contínua exaltação, \\ Jardim quebrado \\ Da imensidão. \\ Estreita taça \\ A transbordar da anunciação \\ Que às vezes nas coisas passa.
}

Considerando a simbologia de poder e dominação que essa imagem agrega - "a mão é um emblema real, instrumento de maestria e signo de dominação. A mesma palavra em hebreu, significa ao mesmo tempo mão e poder" (CHEVALIER e GHEERBRANT, 2007, p.589) - observa-se como no poema a mão do mar, ao moldar o jardim, mantém-no fadado à submissão.

Em outro poema da autora, "Jardim verde e em flor, jardim de buxo", publicado nessa mesma obra, Dia do mar, a relação com o espaço das águas reaparece de uma forma mais leve; a menção ao ondular dos narcisos e a imagem de um poente infinito sobre o jardim permitem que se identifique uma sutil alusão ao ambiente marítimo, na medida em que o sujeito evoca elementos e imagens inerentes a esse meio.

Jardim verde e em flor, jardim de buxo

Onde o poente interminável arde

Enquanto bailam lentas as horas da tarde.

Os narcisos ondulam e o repuxo,

Voz onde o silêncio se embala,

Canta, murmura e fala

Dos paraísos desejados, 
Cuja lembrança enche de bailados

A clara solidão das tuas ruas.

É interessante observar um aspecto. Enquanto o jardim é habitado pelo "poente", pelos "narcisos", e arbustos - "buxo" -, o espaço urbano, ao qual a imagem das "ruas" remete, é marcado pela solidão. A vivacidade e vigor evocados pelo arder do "poente" também se contrapõem à imagem do claro, que pode ser interpretado como algo de "cor pouco intensa" (AURÉLIO, 2001, p. 157). Outra contradição é o ondular (verbo que sugere vida e movimento) de uma flor que, como já foi dito anteriormente, é comumente associada à morte.

Importante tema da obra poética de Sophia, o mar volta à cena de forma mais incisiva no poema "Foi no mar que aprendi" (O Búzio de Cós, 1997), no qual ele aparece como culto ao belo, conforme é possível observar desde os primeiros versos, nos quais o sujeito poético constrói metaforicamente a imagem das ondas em sua beleza intermitente como imagem do prolongamento do sublime. Aliás, nos versos finais da estrofe primeira, a beleza do mar é descrita por meio de características tipicamente humanas e as ondas revelam ter dorso e mãos.

Foi no mar que aprendi o gosto da forma bela

Ao olhar sem fim o sucessivo

Inchar e desabar da vaga

A bela curva luzidia do seu dorso

O longo espraiar das mãos da espuma

Nesse sentido, a perspectiva de Schopenhauer que associa a ideia do sublime àquilo que é grandioso pode ser empregada na interpretação dos versos acima, na medida em que, assim como no poema, o filósofo associa a contemplação do belo à observação de algo vasto e duradouro:

Muitos dos objetos da nossa intuição provocam o sentimento do sublime, pelo fato de que por causa de sua grande extensão, da sua grande antiguidade, da sua longa duração, 
nos sentimos, perante eles, reduzidos a nada a absorvemonos apesar de tudo no gozo de contemplá-los (SCHOPENHAUER, 2001, p.217).

Ao tratar desse tema, Bachelard vai além ao associar a contemplação da grandeza e da imensidão à busca por um mundo que carrega em si possibilidade do infinito:

Poderíamos dizer que a imensidão é uma categoria filosófica do devaneio. Sem dúvida, o devaneio alimenta-se de espetáculos variados; mas por uma espécie de inclinação inerente, ele contempla a grandeza. E a contemplação da grandeza determina uma atitude tão especial, um estado de alma tão particular que o devaneio coloca o sonhador fora do mundo próximo, diante de um mundo que traz o signo do infinito (BACHELARD, 2008, p. 189).

É por essa via que caminha o sujeito poético, a sua procura pela imensidão reflete uma inclinação pela vastidão que habita o próprio "eu". O olhar sem fim para o movimento constante do mar e a referência ao "longo espraiar das mãos na espuma" sugerem a ideia de dispersão, dissolução do indivíduo nas águas. Com base nessa leitura é possível identificar no "espraiar das mãos" uma tentativa do sujeito de tornar-se parte desse ambiente natural.

Na segunda e última estrofe do poema, o belo finaliza por revelar-se tão intrinsecamente associado ao natural, que o sujeito poético confessa sentir-se tão bem e à vontade num museu da Grécia como no mar.

\footnotetext{
Por isso nos museus da Grécia antiga Olhando estátuas frisos e colunas Sempre me aclaro mais leve e mais viva E respiro melhor como na praia
}

Sobre o último verso do poema, é pertinente fazer uma leitura paralela do mar e da praia na obra da autora. Ao mesmo tempo em que é um tema recorrente na criação poética de Sophia, o espaço marítimo (as águas, as ondas, a espuma, a praia, o sal etc.) é mais objeto de admiração do sujeito do que necessariamente um ambiente pelo qual ele se aventura, conforme pondera Carlos Ceia (1996): 
Sophia fala constantemente do mar e das suas criaturas, porém a maior parte das referências marítimas partem de observações e divagações realizadas nas praias. Por esta razão, mais do que uma "poética" fundada na experiência verdadeira da vida marítima, devemos falar antes de uma poesia da navegação onírica de quem prefere contemplar 0 mar a percorrer realmente as suas águas (CEIA, 1996, p. 64).

Considerando a obra da poeta, é possível observar em alguns poemas uma relação tão íntima entre o espaço natural e o "eu" poético que este último estabelece com o meio uma relação de identificação, como acontece no poema abaixo, publicado na obra Coral (1950). Neste texto composto por apenas um quarteto, o sujeito poético busca encontrar-se em tudo o que é da ordem do espaço natural, a começar pelo mar, num contexto em que é nesse ambiente que o indivíduo se reconhece:

Chamei por mim quando cantava o mar

Chamei por mim quando cantavam fontes

Chamei por mim quando os heróis morriam

E cada ser me deu sinal de mim.

Já no primeiro verso, o emprego do pretérito imperfeito do indicativo relacionado ao canto do mar sugere um ar saudoso motivado não pela perspectiva das navegações e suas conquistas, mas pela ideia da natureza primordial que nele habita. Retomando o ponto de vista de Carlos Ceia, a freqüente incidência do tema marítimo na obra poética da autora deve ser sempre lida sob o prisma da sua "positividade elemental":

[...] porque não vamos encontrar nesta poesia nenhum testemunho digno da interminável história trágico-marítima portuguesa e das paixões que sempre despertou no imaginário português. Os mares de Sophia estão sempre invadidos daquela tranqüilidade a que os gregos antigos chamavam Sophrosyne (CEIA, 1996, 69).

Se espaços naturais como "mar" e "fonte", presentes no poema acima, aludem a um ambiente de júbilo para o sujeito poético, o mundo criado pelo homem surge, em contrapartida, para rivalizar diretamente com o espaço natural. Em "Eu me perdi”, publicado em Geografia (1967), aquele meio tem seu aspecto negativo potencializado desde o primeiro verso: 
Eu me perdi na sordidez de um mundo

Onde era preciso ser

Polícia, agiota, fariseu

Ou cocote

Na estrofe acima, que abre o poema, o espaço habitado pelo homem é descrito como um universo que causa asco e repugnância no sujeito, o qual por sua vez, tem seu drama potencializado na medida em que se sente corrompido nesse ambiente muito próximo, aliás, do que Deleuze e Guattari (2008) definem como espaço estriado, conforme se aproxima da imagem que se tem da própria cidade, tema central do próximo capítulo: "Ao contrário do mar, ela [a cidade] é o espaço estriado por excelência [...]" (p. 188). Segundo a perspectiva de Deleuze e Guattari, uma das características mais marcantes daquilo que é da ordem do espaço estriado é que ele está "necessariamente delimitado". A simbologia do espaço citadino, que entre interpretações diversas também está relacionado à ideia de "limite" (CHEVALIER e GHEERBRANT, 2007, p.239), salienta a relação entre cidade e espaços estriados.

Em oposição a essa atmosfera regida pelo desconcerto frente a esse espaço degradante, o ambiente natural aparece como ícone da salvação do sujeito, que encontra na terra, no mar e no vento sua verdadeira identidade.

A imagem do navio, por sua vez, evoca a ideia de uma travessia: "É a imagem da vida, cujo centro e direção cabe ao homem escolher" (Chevalier e Gheembrant, 2007, p.632).

\footnotetext{
Eu me perdi na sordidez do mundo

Eu me salvei na limpidez da terra

Eu me busquei no vento e me encontrei no mar

E nunca

Um navio da costa se afastou

Sem me levar
}

A imagem do meio onde há ação do homem como espaço de desconforto para o sujeito poético aparece, também, na obra No tempo Dividido (1954), na qual o poema "Quadro" traz um outro tema recorrente na modernidade, a cisão: 
Indeciso ressurge do poente

Aureolado de espanto e de desastres

Em busca do seu corpo dividido

Já no primeiro verso, essa ideia é apresentada na figura de um sujeito cuja existência está fadada à incerteza, o emprego do adjetivo "indeciso" permite essa interpretação. O estado de incômodo permanece em outras passagens da mesma estrofe. No segundo verso, a "auréola", símbolo comumente associado à luz espiritual e à conquista da glória (CHEVALIER e GHEERBRANT, 2007, p 100), assume um sentido oposto ao ser combinado com os substantivos "espanto" e "desastres", reforçando o drama de um sujeito que se revela cindido.

Nesse contexto, é interessante observar como a imagem aterradora do meio criado pelo homem surge com mais potência na estrofe seguinte, reiterado por imagens como "sombras", "esquinas" e "cães". Tudo isso reforça o espaço tortuoso e permeado por sacrifícios no qual esse sujeito está inserido:

Todas as sombras se erguem das esquinas

E o seguem devagar nas ruas verdes

São como cães no rastro dos seus passos

Nessa aparente fuga, nem mesmo chegando ao seu destino, o sujeito se vê livre de sua sina incerta: "Aberta a porta o quarto grave surge / E os espaços oscilam nas janelas". Conhecida como local de passagem entre dois locais, a porta, segundo Chevalier e Gheerbrant, simboliza a transição entre dois mundos "entre o conhecido e o desconhecido, a luz e as trevas, o tesouro e a pobreza extrema". Num contexto em que o sujeito se encontra imerso no caos e na incerteza, a figura da porta, no poema em questão, pode ser interpretada como transição ou como fuga. Para reforçar essa interpretação, recorra-se a Chevalier e Gheerbrant, que definem essa travessia como uma mudança de um estado pior para um melhor: "A passagem à qual ela [a porta] convida é, na maioria das vezes, na acepção simbólica, do domínio profano ao domínio sagrado" (2007, p. 734-735).

No entanto, mesmo buscando essa transição, o sujeito parece ter seu sonho malogrado, a promessa de mudança sugerida pela simbologia da porta cai por terra assim que ela é aberta. Diante do sujeito, surge a paisagem de um 
quarto grave cujo horizonte, revelado através das janelas - símbolo da receptividade - também é incerto.

O tempo de incerteza que perpassa os versos de "Quadro" se transforma no "tempo dos suplícios e dos nojos" do poema "Serenamente sem tocar nos ecos", de No Tempo Dividido. Desta vez, o sujeito que está a percorrer um "estreito caminho" reaviva a busca pelo primordial na procura por um rosto puro. No excerto abaixo, a ideia da pureza aparece como uma ferramenta com a qual esse indivíduo vê-se preparado para lidar com as adversidades do seu tempo. É interessante observar a imagem que se forma com este último verso, no qual se sonha com um tempo em que possa se espelhar diante do mar sem pejo:

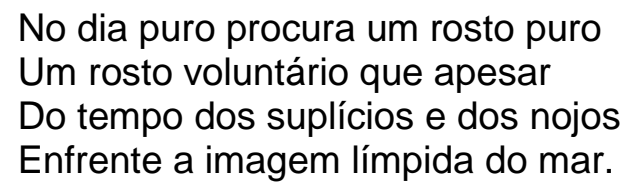

Em "O Hospital e a Praia", publicado em Livro Sexto, observa-se mais uma vez o conflito entre o espaço natural, virgem e imaculado, e o espaço habitado pelo homem, de onde irrompe a escuridão e o sofrimento. Nesse poema, é interessante observar como elementos simbólicos inerentes ao conceito de limpidez e claridade assumem sentidos opostos:

\footnotetext{
E eu caminhei no Hospital Onde o branco é desolado e sujo Onde o branco é a cor que fica quando não há cor E onde a luz é cinza
}

Na estrofe acima, que abre o poema, é possível observar que, conforme as imagens inerentes ao espaço natural se deslocam para o ambiente corrompido pelo homem, elas sofrem mudanças em seu sentido original. Aqui, o conceito de pluralidade das imagens, de Octavio Paz, pode ser identificado na mudança que a simbologia da cor branca e da luz sofrem. Antes associado ao conceito daquilo que é puro, o branco agora remete à ideia de algo sujo. Sempre ligada à ideia de vida, a luz, por sua vez, ganha nuances sombrias, na medida em que se revela cinza no hospital. Ao tratar dessa ambivalência de sentidos, o poeta e ensaísta mexicano aponta: 
As palavras se conduzem como seres caprichosos e autônomos. Sempre dizem 'isto e o outro' e, ao mesmo tempo, 'aquele e o mais além'. O pensamento não se resigna; forçado a usá-las, uma e outra vez a linguagem se rebela e rompe os diques da sintaxe e do dicionário (PAZ, 2005, p. 49) ${ }^{6}$.

Na mesma linha, Bachelard chama atenção para a natureza instável da imagem, que, além de jamais se prender a sentidos definitivos, também caminha sobre a tênue linha da tensão:

E quanto às imagens, logo fica evidente que atrair e repelir não resultam em experiências contrárias. Os termos são contrários. Ao estudarmos a eletricidade ou o magnetismo, podemos falar simetricamente de repulsão e atração. Basta uma ideia de sinais algébricos. Mas as imagens não aceitam ideias tranqüilas, nem sobretudo ideias definitivas. Incessantemente a imaginação imagina e se enriquece com novas imagens (BACHELARD, 2008, p. 19).

Mas, se os versos iniciais de "O hospital e a praia" configuram um cenário invertido, na segunda estância, o espaço natural surge para confrontar o ambiente maculado pelo homem; fazendo frente à ideia de clausura que um espaço fechado como o hospital pode vir a sugerir, o sujeito defronta-se agora com um espaço aberto, a praia, onde ele caminha "livre como um deus", como é possível observar nos versos que seguem:

E eu caminhei nas praias e nos campos
O azul do mar e o roxo da distância
Enrolei-os em redor do meu pescoço
Caminhei na praia quase livre como um deus

$\mathrm{Na}$ medida em que o sujeito busca fazer da vastidão do meio natural um prolongamento do seu ser, é interessante traçar uma relação entre a profundidade do mundo e a profundidade do ser íntimo da qual fala Bachelard ao afirmar que "diante de uma imensidade evidente, como a imensidade da

\footnotetext{
${ }^{6}$ Tradução livre do seguinte trecho:

"Las palavras se conducen como seres caprichosos y autônomos. Siempre dicen 'esto y lo outro' y, al mismo tiempo, 'aquello y lo de más allá'. El pensamiento no se resigna; forzado a usarlas, uma y outra vez el lenguaje se rebela y rompe los diques de la sintaxis y del diccionario."
} 
noite, o poeta pode nos indicar os caminhos da profundidade íntima" (BACHELARD, 2008, p. 194). Nesse contexto, ao enrolar em redor do seu pescoço a vastidão das praias, do mar e dos campos, o sujeito procura a grandeza íntima que o mundo exterior "vem ajudar a revelar", segundo Bachelard (p.197).

Nessa busca pela comunhão com o natural, é interessante, por fim, observar que o real natural por si só já basta para o "eu" poético. É como se diante do esplendor desse meio distante da intervenção do homem os questionamentos e as explicações fossem supérfluas:

Não perguntei por ti à pedra meu Senhor Nem me lembrei de ti bebendo o vento $O$ vento era vento e a pedra pedra

$E$ isso inteiramente me bastava

E nos espaços da manhã marinha Quase livre como um deus eu caminhava

Porém no hospital eu vi o rosto Que não é pinheiral nem é rochedo E vi a luz como cinza na parede E vi a dor absurda e desmedida 


\title{
4. Mar de concreto: uma leitura da cidade e de sua relação com o mar nos poemas de Sophia de Mello Breyner Andresen
}

\author{
"Ó cidade, cidade, que transbordas \\ De vícios, de paixões e de amarguras! \\ Tu lá estás, na tua pompa envolta, \\ Soberba prostituta [...]" \\ "[...] Cidade, \\ Branqueado sepulcro, que misturas \\ A opulência, a miséria, a dor e o gozo, \\ Honra e infâmia, pudor e impudícia \\ Céu e inferno, que és tu? Escárnio ou glória \\ Da humanidade? O que o souber que 0 \\ diga!"
}

(Alexandre Herculano, "A Arrábida")

Como já foi visto no capítulo anterior, na poesia de Sophia de Mello Breyner Andresen, a busca incessante do real em todos os seus ângulos tem no aspecto espacial um de seus pontos mais marcantes. Regida pelas idiossincrasias de um mundo onde ambiente natural e meio moldado pelo homem constituem, respectivamente, espaços de identificação e desconforto para o sujeito poético, a obra da autora tem a cidade como imagem de dualidade.

Apesar de num primeiro momento remeter a um espaço corrompido e hostil, comumente associado à escuridão e causador da cisão no indivíduo, a representação da cidade na obra da poeta está longe de se esgotar nessa leitura. O estudo pormenorizado no presente capítulo mostrará como é possível entrever na poesia da autora portuguesa outras leituras desse espaço. A partir delas será possível identificar nuances das cidades délficas, que se aproximam daquela que sucede a queda de Babilônia no Apocalipse, assim como as dualidades por trás das luzes e sedas das cidades sedutoras, que fascinam e inebriam o olhar de flaneur do sujeito poético, e ainda as percepções sinestésicas nauseantes do "eu" que se põe a vagar pela selva urbana.

Num contexto em que o espaço citadino congrega realidades plurais e até mesmo contrárias, fundadas na sua unidade original, um conceito-chave que sustenta a análise desse espaço na obra da autora vem do filósofo grego 
Heráclito e se baseia no conceito de harmonia entre os contrários, segundo 0 qual "todas as coisas se originam na discordia"7 (1963, p.42).

A leitura desse conceito original do pensador pré-socrático na contemporaneidade também ajudará a complementar o estudo da imagem a partir da perspectiva de Octavio Paz (1982), que se aproxima da abordagem do real em Sophia ao reiterar a identificação entre os contrários no universo:

Épica, dramática ou lírica, condensada numa frase ou desenvolvida em mil páginas, toda imagem aproxima ou conjuga realidades opostas, indiferentes ou distanciadas entre si. Isto é, submete à unidade a pluralidade do real (p.120).

A partir de uma temática extremamente forte na obra poética de Sophia - a unidade imanente nas relações antagônicas -, o presente trabalho, além de apontar os desdobramentos das relações dualistas suscitadas pela imagem da cidade, vai oferecer uma leitura paralela de outro espaço, o mar. Apesar de num primeiro momento representar um contraponto das desventuras e cisões vivenciadas pelo sujeito poético no meio urbano, à medida que se configura como espaço de júbilo e contentamento, o mar desempenha um papel que vai além do confronto com o ambiente citadino. Na eterna busca pelo primordial, em vários momentos ele surge como elemento essencial na configuração da cidade délfica idealizada pelo sujeito poético.

Nesse sentido, é interessante iniciar o estudo dos poemas alusivos ao espaço urbano por uma perspectiva da cidade que transita entre esses dois extremos: a da metrópole sedutora. Descrita como cidade magnética, ela chama a atenção pelos seus brilhos, cores e aromas inebriantes. Entretanto, revela ao mesmo tempo um fulgor falseado, muitas vezes chegando a ser referida, inclusive, como cidade alheia.

Um exemplo do fascínio e da atração exercidos pelo espaço citadino sobre o sujeito poético já aparece na primeira obra da autora, Poesia, no poema "Há cidades acesas na distância", que traz logo no primeiro verso uma imagem do espaço urbano relacionada à luz ("acesas"). Considerando o sentido celestial que a imagem da luz evoca - "do ser humano quando

\footnotetext{
${ }^{7}$ Tradução livre do seguinte trecho: "todas las cosas se originan en la discordia" (1963, p.42).
} 
purificado e liberto das impurezas que obscurecem o seu ser" (FERREIRA, 2008, p.118) -, já se tem do poema a percepção de um "eu" que, de alguma forma, deixa aparecer sua busca pela luz.

Nesse contexto, é interessante observar como esse espaço se revela num patamar inacessível, assim como os astros o são para o homem. Tem-se aqui a imagem de um sujeito poético que se posiciona longe da cidade, assim como o homem está distante da lua, introduzida no verso seguinte: "Magnéticas e fundas como luas". O magnetismo atribuído a esse espaço remete à ideia de atração que, aliás, está muito próxima daquela que a lua exerce sobre as pessoas, muito comum no Romantismo - leia-se os versos de Herculano no poema "A arrábida": "Da Lua - astro de paz, astro que chama / Os olhos para o céu [...]". De modo que, assim como a lua, a cidade é dotada de uma natureza sedutora que lhe é inerente.

Ainda é interessante observar que o sujeito poético confere às cidades um caráter hiperbólico não somente por compará-las à lua, mas também por estabelecer uma relação baseada na ideia de profundidade: "Há cidades acesas na distância / Magnéticas e fundas como luas". O termo "fundas" intensifica a leitura que o sujeito poético faz do espaço urbano no contexto da sua forte luminescência. Nesse sentido a imagem poética evocada pelas cidades "fundas como luas" revela ter uma natureza orientada pela "filosofia do excessivo" apresentada por Bachelard ao discorrer sobre aquilo que define como "dialética da profundidade":

E, uma vez mais, vemos ativar-se uma dialética da imensidão e da profundidade. Não sabemos onde fica o ponto de partida das duas hipérboles, a hipérbole do olho que vê demais e a hipérbole da paisagem que se vê confusamente sob as pesadas pálpebras de suas águas adormecidas. Mas toda doutrina do imaginário é obrigatoriamente uma filosofia do excessivo. Toda imagem tem um destino de engrandecimento (BACHELARD, 2008, p.213-214).

Nesse sentido, é interessante atentar para a percepção da lua como símbolo do inacessível e como essa tradição tem-se inscrito na literatura ao longo dos anos, como nos versos do poeta da segunda geração do romantismo brasileiro Álvares de Azevedo - "Canto à lua de noite serenatas" - nos quais comumente ela aparece sob a imagem do inalcançável para o sujeito. 
Ampliando a leitura desse elemento para as diferentes interpretações possíveis de uma mesma imagem, é pertinente lembrar que a natureza dual da lua - símbolo tanto da porta do céu quanto do inferno - também incide em torno da luz falseada que dela emana: "Suas características mais fundamentais derivam, de um lado, de a lua ser privada de luz própria e não passar de um reflexo do sol" (CHEVALIER e GHEERBRANT, 2007, p.651). Tal comparação sugere que, assim como a lua emite uma luz que não é dela, a cidade também emite sua luz artificial, de modo que ambas exercem um fascínio falseado.

Da mesma forma, o verso que encerra a estrofe inicial do poema "Cheias de exaltação e ressonância" - alude tanto à ideia de arrebatamento e estado de glória, quanto à percepção de algo que vibra numa frequência própria. Nessa passagem, pode se observar claramente a movimentação e agitação que permeiam a rotina desse ambiente, que por sua vez, também é povoado por sons. Esse é o primeiro índice de percepção sensorial da cidade. O segundo aparece na estrofe seguinte e se dá por meio da apreensão sinestésica, quando o sujeito chama a atenção para o "lume" (visão) e para o "perfume" (olfato) que emanam do espaço citadino:

\author{
Há cidades cujo lume \\ Destrói a insegurança dos meus passos, \\ E o anjo do real abre seus braços \\ Em nardos que me matam de perfume.
}

No segundo verso da estrofe acima mencionada observa-se que a luz que habita a cidade, de tão intensa, ainda que falseada, transmite segurança ao sujeito poético que caminha pela noite. Nos dois versos seguintes é interessante observar como a sedução desse meio sobre o sujeito o incita cada vez mais, agora por meio da figura do "anjo do real", que se vê dotado de "braços" para recebê-lo. É interessante observar como aqui se tem uma figura intermediária entre Deus e o mundo - o anjo. Este completa o cenário sedutor acolhendo o sujeito inebriado pelo aroma dos "nardos".

Nesse momento é pertinente observar o viés duvidoso que paira sobre a imagem do "anjo do real". Além de revelar a figura angelical associada a um espaço, em muitos poemas da autora, retratado como corrompido e corruptor a cidade -, o poema remonta ao aroma dos nardos. Estes, ao mesmo tempo em que remetem à humildade - já que essa é a planta com a qual Magdalena 
lavou os pés de Jesus - também são conhecidos pelo perfume inebriante extraído de suas raízes. Daí a leitura duvidosa da figura do anjo.

Nesse cenário rodeado por incertezas, o sujeito poético sente necessidade de partir, ele precisa se distanciar para poder ter o discernimento que não consegue alcançar dentro do espaço urbano:

\section{E eu tenho de partir para saber Quem sou, para saber qual é o nome Do profundo existir que me consome Neste país de névoa e de não ser.}

Nos versos finais do poema é possível observar que o sujeito, ainda que atraído pelo espaço citadino, precisa abandonar esse meio sedutor para poder ter clarividência suficiente para alcançar sua própria identidade. A revelação do poema se faz presente no verso final, no qual o drama do sujeito, suas incertezas revestidas de luminosidade, seus enganos perpetrados pelos perfumes inebriantes do nardo revelam ter uma raiz que transcende os limites da cidade e aponta para a imagem de Portugal, mergulhado na ditadura. $\mathrm{O}$ drama do sujeito incide sobre um país de "névoa e de não ser" que limita a existência e a identidade do indivíduo. No tocante à ideia de "anulação" do indivíduo, é possível entrever um paralelismo entre o país sob o regime ditatorial e a cidade, na medida em que na perspectiva de La Salette Loureiro,

A Cidade, sobretudo, a capital, é também o local que gera a perda de autenticidade, o reino das aparências, o que Rousseau explica pelo afastamento das Coisas e a aproximação dos homens, que engendra todos os vícios (1996, p.33).

O poder de atração da cidade também é referenciado no poema "As cidades", publicado em Dia do Mar. Aqui o espaço urbano surge habitado por um esplendor reluzente que exerce um poder sedutor. Um dos pontos mais marcantes do breve poema é a plasticidade que permeia o primeiro verso: "Estavam no poente luzidias". Aqui tem-se a figura de um sujeito poético que se põe a contemplar o espaço urbano num fim de tarde. Ocorre que, da linha do horizonte observada por ele, a cidade iluminada aparece tendo como pano de 
fundo o poente e, nas malhas do texto, eles aparecem juntos compondo uma mesma paisagem.

Outro aspecto que merece menção é o fascínio pela cidade e seu emaranhado de luzes num contexto em que o espaço urbano chega a fazer frente à imagem do céu permeado de estrelas que sucede o pôr-do-sol. 0 ambiente citadino detém uma capacidade de atração sem par, capaz de afrontar o "infinito céu das tardes frias".

Estavam no poente luzidias, Acesas e magnéticas chamando

Sob o infinito céu das tardes frias.

A respeito do infinito é pertinente observar a leitura bachelardiana do céu como espaço aéreo sem limite. Seguindo por esse ponto de vista, a imensidão surge como um ambiente propício aos sonhos: "Nessa imensidão do céu tudo é leve e na contemplação fundem-se a leveza e o aéreo nos devaneios do poeta" (FERREIRA, 2008, p.39).

É interessante observar em quais circunstâncias o espaço urbano aparece com esse viés diferente, na medida em que é sob a égide do poente que o aspecto sombrio e denso da cidade dá lugar aos ideais de leveza e luz, como se, apenas através da aproximação com aquilo que é da ordem do elementar, a cidade conseguisse assumir novas nuances. Por falar em novas nuances, até mesmo a autenticidade da claridade que perpassa esse ambiente é questionável, haja vista que a imagem das cidades "luzidias" pode ser consequência do reflexo da própria luz emitida pelo sol no fim de tarde.

Nesse sentido, o poema em questão já dá os primeiros sinais de um aspecto que será aprofundado mais adiante no estudo do espaço urbano na obra de Sophia. A cidade só parece manifestar seu viés positivo quando associada àquilo que é da ordem do elementar, no caso em questão, o sol poente.

O espaço urbano e seu resplendor falseado também é o ponto de partida do poema "Nocturno da Graça" (Mar Novo). Mas, antes de adentrar nessa leitura é interessante atentar para o título "Noturno da Graça", que logo de início evoca o cenário no qual a cidade vai irromper sua exposição de brilhos e cores, a noite. Relacionada com o "passivo, o feminino e o 
inconsciente", a noite recebeu do poeta da Grécia Antiga, Hesíodo, o nome de mãe dos deuses, já que para os gregos ela precederia a formação de todas as coisas. "Por isto, como as águas, [a noite] tem um significado de fertilidade, virtualidade, semente" (CIRLOT, 2005, p. 409).

Quando se considera o termo ao qual a noite é associada - "graça", que remete a um favor outorgado por Deus - tem-se no título a tentativa do sujeito poético de trazer para o espaço urbano um estado sublime, ainda que efêmero.

Esse é o estado inicial, que aparece em diversos poemas da autora. É como se o espaço urbano tivesse seu fulgor roubado do resplandecer das estrelas. Ao longo de todo o poema o sujeito poético parece ter plena noção de que a luminância que emana da cidade não é deveras autêntica, até porque a noite também pode ser lembrada, no contexto da própria literatura, como 0 ambiente propício às perversões, vide os contos de Noite na Taverna, de Álvares de Azevedo, e os versos de "Crepúsculo Vespertino", em que Baudelaire chama atenção para a concupiscência da noite com as contravenções: "Eis a noite sutil, amiga do assassino / Ela vem como um cúmplice, a passo lupino". Observa-se que, o intuito do sujeito poético de transgredir a configuração original do espaço urbano agregando à imagem da noite uma natureza sagrada evocada pelo título - "Nocturno da graça" - vai ao encontro da perspectiva bachelardiana analisada por Agripina Encarnación Alvarez Ferreira, fundamentada na concepção de que a imaginação "deforma, transforma e transfigura o real numa obra de arte, imprimindo-lhe a marca e a força projetante de seu criador" (2008, p.157).

Nesse sentido, é interessante observar como já no primeiro verso, temse uma prévia de como espaço urbano subtrai do ambiente noturno algumas propriedades do espaço natural, para apresentar a cidade como um local mais aprazível.

Há um rumor de bosque no pequeno jardim

Um rumor de bosque no canto dos cedros

Sob o íman azul da lua cheia

$O$ rio cheio de escamas brilha.

Negra cheia de luzes brilha a cidade alheia.

Na passagem acima é possível observar, no primeiro verso, que o jardim urbano, um pequeno recorte do meio natural, moldado pelo homem, evoca uma 
formação vegetal de dimensão maior: o bosque. Daí que uma expressão do mundo exterior do sujeito e que está ao alcance dos seus olhos, o "jardim", dentro do poema o remete à imensidão, materializada na imagem poética do "bosque": "Há um rumor de bosque no pequeno jardim".

Uma leitura possível de tal verso é que em sua ânsia por transcender um espaço cerceante (a cidade do jardim), na impossibilidade de romper os limites desse meio que 0 aprisiona, 0 sujeito acaba materializando poeticamente outra perspectiva da cidade (regida pela imensidão do bosque), ainda que essa existência seja fatalmente efêmera. Ao encontro dessa leitura, cite-se Bachelard:

Embora pareça paradoxal, muitas vezes é essa imensidão interior que dá seu verdadeiro significado a certas expressões referentes ao mundo que vemos. Para discutirmos sobre um exemplo preciso, vejamos a que corresponde a imensidão da Floresta. Essa 'imensidão' nasce de um corpo de impressões que não derivam realmente de ensinamentos de geografia. Não é preciso permanecer muito tempo nos bosques para conhecer a impressão sempre um pouco ansiosa de que 'mergulhamos' num mundo sem limites (BACHELARD, 2008, p.191).

Nesse mesmo cenário permeado pela plasticidade, assim como no poema anterior, a lua cheia já anuncia seu poder de atração com o característico "íman azul". É curioso observar que a luz lunar, reflexo do sol, como já ficou dito, proporciona uma bela imagem completamente protagozinada por elementos do meio natural. Ao refletir sobre as águas do rio, ela causa a impressão visual de que este está coberto de escamas reluzentes. Tentando fazer frente a essa paisagem, a cidade também emite luzes, entretanto estas são artificiais, o que remete, por sua vez, à imagem negativa da "dolorosa luz das grandes lâmpadas eléctricas" do verso de abertura da "Ode triunfal", do heterônimo pessoano Álvaro de Campos.

Não por acaso, desde a primeira estrofe, o sujeito é enfático em mostrar que aquele ambiente está longe de ser mais acolhedor, haja vista que ele nem o reconhece como seu: "Negra cheia de luzes brilha a cidade alheia", passagem que, aliás, dialoga diretamente com o poema "Os sete velhos" de Baudelaire à medida que o sujeito revela ter rompido por completo o vínculo com esse ambiente, misto de espaço onírico e sombrio: 
Cidade a fervilhar, cheia de sonhos, onde O espectro, em pleno dia agarra-se ao passante!

[...]

Certa manhã, quando na rua triste e alheia,

$[\ldots]$

"Os sete velhos" (Flores do Mal)

A estrofe seguinte do poema de Sophia reforça essa percepção do espaço urbano como um meio munido de um poder ludibriante, seja pelas promessas sedutoras das propagandas, seja pelo prazer soturno. Vale atentar para a ausência de pontuação, que incute no leitor uma sensação de apreensão instantânea, num contexto em que as imagens vão sendo lançadas sem tempo para pausas, resultando num paralelismo com o próprio fascínio imediato que a visão radiante da cidade provoca num primeiro momento:

Brilha a cidade dos anúncios luminosos, Com espiritismo bares cinemas

Com torvas janelas e seus torvos gozos

Brilha a cidade alheia.

Nesse momento, é interessante observar algumas relações que podem ser estabelecidas entre a passagem acima e a terceira parte de "O sentimento dum ocidental" ("Ao Gás"), do poeta Cesário Verde, no sentido de os dois textos poéticos fazerem alusão à artificialidade que acaba por se tornar demasiado pesada e cansativa para o indivíduo. Da mesma forma que a cidade de Sophia é permeada pelas luzes artificiais e pela movimentação da vida noturna, as vitrines resplandecentes da vida urbana materializada nos poemas de Cesário enfastiam o sujeito poético:

Mas tudo cansa! Apagam-se nas frentes

Os candelabros, como estrelas, pouco a pouco;

Da solidão regouga um cauteleiro rouco;

Tornam-se mausoléus as armações fulgentes.

“Ao Gás / O Sentimento Dum Ocidental” (O livro de Cesário

Verde)

Voltando à análise de "Nocturno da Graça", observa-se que na terceira estrofe, como se o sujeito poético fosse despindo a cidade de suas máscaras, 
tem-se a real configuração desse espaço, a partir de todos os seus protagonistas. "Becos", "esquinas", "tristes candeeiros", "gritos abafados", "ruídos dos carros", "vultos"... tudo confere um ar sombrio ao espaço citadino. Novamente, a ausência de pontuação contribui para uma percepção da paisagem urbana através de um conjunto de imagens justapostas. O verso que encerra a estrofe é o único que vem acompanhado por um ponto final. É pertinente observar como ele finaliza esse retrato da cidade evocando a figura do gigante mitológico "geralmente dotado de um olho só" (CIRLOT, 2005, p.161).

Com seus bairros de becos e escadas

De candeeiros tristes e nostálgicas

Mulheres lavando a loiça em frente das janelas

Ruas densas de gritos abafados

Castanholas de passos pelas esquinas

Viragens chiadas dos carros

Vultos atrás das cortinas

Cíclopes alucinados.

Esse ritmo alucinado e alucinante da cidade evoca, mais uma vez, uma passagem da "Ode Triunfal", na qual se parte da percepção sinestésica dos ardores, odores e cores circundantes nesse espaço para trazer à luz os excessos que permeiam as cidades: "A todos os perfumes de óleos e calores e carvões / Desta flora estupenda, negra, artificial, insaciável!"

$\mathrm{Na}$ estrofe seguinte tem-se uma espécie de pausa ilusória, como se, ao som dos sinos e da relação com o sagrado que esse símbolo evoca - "Seu som é símbolo do poder criador" (CIRLOT, 2005, p.533)" -, o espaço urbano pudesse assumir uma essência de pureza semelhante àquela que habitava a "antiga cidade" primordial:

De igreja em igreja batem a hora os sinos

E uma paz de convento ali perdura

Como se a antiga cidade se erguesse das ruínas

Com sua noite trémula de velas

Cheia de aventurança e sossego.

Observando a estrofe acima, pode ser traçado um paralelo entre a "antiga cidade" que o sujeito evoca no terceiro verso ao ouvir o badalar dos sinos e a Jerusalém celeste. Por um instante, é como se a "Jerusalém do alto", 
aquela que "gera através do espírito", assumisse o lugar da "cidade alheia" mencionada nos demais versos do poema.

Entretanto, já na estrofe seguinte, o sujeito revela ter plena consciência de que a promessa de "aventurança e sossego" é ilusória e que persiste ainda a perspectiva babilônica das velhas capitais "onde até mesmo o horror se enfeita de esplendores", leia-se no poema "As velhinhas", de Baudelaire. Enquanto nos versos do poeta francês a beleza mascara a feiúra, nos de Sophia o "brilho" e as "luzes fluorescentes" desempenham o papel de camuflar a escuridão:

\section{Mas a cidade alheia brilha \\ Numa noite insone \\ De luzes fluorescentes \\ Numa noite cega surda presa \\ Onde soluça uma queixa cortada.}

Sobre as duas últimas estrofes mencionadas acima, convém observar como ambas exemplificam a ambivalência que se abriga sob a égide da imagem poética, no sentido de a primeira apresentar "direções que, embora opostas, aproximam-se e harmonizam-se graças aos sonhos e aos devaneios" (FERREIRA, 2008, p.18).

$\mathrm{Na}$ última estrofe, observa-se que além de constantemente se referir ao espaço urbano como um espaço alheio, leia-se o verso que abre a estância "Mas a cidade alheia brilha - o "eu" reforça que seu fulgor se mostra numa "noite insone" e que as luzes que sustentam esse brilho são artificiais "fluorescentes". Nessa noite "cega surda presa" o único que não se encontra ludibriado é o "eu" poético. Os dois últimos versos em especial permitem até um paralelo entre a condição do indivíduo e a situação de ditadura e censura ferrenha vivenciada por Portugal na época em que a obra foi escrita: "Numa noite cega surda presa / Onde soluça uma queixa cortada."

$\mathrm{Na}$ estrofe que encerra o poema, o eu revela a solidão à qual o ser $\mathrm{e}$ estar consciente o condena:

Sozinha estou contra a cidade alheia.

Comigo

Sobre o cais sobre o bordel e sobre a rua

Límpido e aceso

O silêncio dos astros continua. 
Ao mesmo tempo, o "eu" não é o único a testemunhar a consciência do real, haja vista que as estrelas, dotadas de luz própria, também estão diante daquele cenário e presenciam os flagrantes da cidade que emite esplendores falseados.

O poema "A estrela" (Livro sexto) apresenta um sujeito que percorre caminhos tortuosos e sombrios guiado por um astro que, num primeiro momento, julga ser mero reflexo "de uma cidade a neón enfeitada."

\author{
Eu caminhei na noite \\ Entre silêncio e frio \\ Só uma estrela secreta me guiava \\ Grandes perigos na noite me apareceram \\ Da minha estrela julguei que eu a julgara \\ Verdadeira sendo ela só reflexo \\ De uma cidade a néon enfeitada
}

Esse sujeito por vezes vivencia enganos, ora em torno da cidade, ora em torno de si mesmo. Nessas idas e vindas, o "eu" ora acredita ser a estrela real, ora falseada, até que, a certa altura, ele descobre que a estrela que seguia o guiava para a "cidade dos homens". Nesse ambiente, do qual o "eu" já se desvincula ao se referir a ele como "cidade dos homens", observa-se um cenário apático e sombrio, onde a luz é cinza e sua cor não tem viço. Tudo se contrapõe ao espaço natural, representado pelo "verde azul da natureza" e pelo cintilar do sol:

\footnotetext{
E a estrela do céu parou em cima de uma rua sem cor e sem beleza Onde a luz tinha a cor que tem a cinza Longe do verde azul da natureza

Ali não vi as coisas que eu amava Nem o brilho do sol nem o da água
}

E eis que, na contramão, aquela cidade, disfarçada de estrela, abrigava a corrupção do "agiota" e o pecado do "templo profanado", de modo que o sujeito, por fim, lamenta tanto ter vagado e enfrentado para se deparar com aquilo que estava tão próximo dele. 
Considerando que no poema analisado acima é possível observar índices do conceito original de Heráclito, fundado na harmonia de tensões opostas "como a do arco e da lira" (1963, p. 43) num contexto em que ambos se sucedem, haja vista que, para o filósofo é impossível a simultaneidade (p.41-42), é interessante atentar para a evolução desse pensamento em Octavio Paz por meio de um conceito que vai ao encontro da situação vivenciada no poema "Cidades e ciladas", publicado em Navegações. O texto poético em questão proporciona leituras diferentes e coexistentes desse mesmo espaço, estimulando uma reflexão sobre a dualidade imanente da imagem poética:

\section{Cidades e ciladas \\ Mas também \\ O pasmo de tão grande arquitetura \\ As sedas os perfumes a doçura \\ Das vozes e dos gestos \\ Os grandes pátios da noite e sua flor \\ De pânico e sossego}

Se, na primeira estrofe, o espaço urbano é apresentado como sítio de armadilhas e traições - "Cidades e ciladas" -, trazendo à superfície a face ardilosa de seus habitantes, já no segundo verso, uma leitura complemente inversa - porém coexistente e simultânea - se anuncia. Pela combinação de uma conjunção adversativa ("Mas") com um advérbio que reforça o contraponto ("também"), a outra imagem da cidade - a da suntuosidade sedutora - logo se revela: "O pasmo de tão grande arquitetura".

Para compreender a extensão dessa dualidade, é interessante chamar a atenção para o princípio da contradição complementária desenvolvido por Octavio Paz, que aponta para o sentido plural e para a coexistência de sentidos contrários no campo da imagem poética:

Cada imagem - ou cada poema composto de imagens contém muitos significados contrários ou díspares, aos quais abarca ou reconcilia sem suprimi-los (2005, p.119).

\footnotetext{
${ }^{8}$ Tradução livre do seguinte trecho: "como la del arco y la lira" (1963, p. 43).
} 
Nos versos seguintes - "Pasmo de tão grande arquitetura / As sedas os perfumes a doçura / Das vozes e dos gestos" -, a grandiosidade desse espaço é adornada por imagens sinestésicas de um ambiente povoado por sedas (tato), perfumes (olfato), doçura (paladar), vozes (audição) e gestos (visão). Além de mais sensível, é interessante observar que a percepção sensorial, muito comum nos poemas de Sophia Andresen, também é observada por Bachelard como uma forma mais precisa de se estudar a imagem:

Se multiplicássemos as imagens, tomando-as nos âmbitos da luz e dos sons, do calor e do frio, prepararíamos uma antologia mais lenta, mas sem dúvida mais segura que aquela que se baseia nas imagens geométricas (2008, p. 218-219).

Apesar desse ambiente de sedução que se cria em torno do espaço citadino, encaminhando a análise para a estrofe final do poema - um dístico o misto de fascinação e repulsa que povoa o espaço urbano volta a assombrar, motivado pelos "grandes pátios da noite" e "sua flor / De pânico e sossego". A dualidade presente em "Cidades e ciladas" também pode ser identificada nos versos de Baudelaire, extraídos do poema "Os cegos": "[...] Ó cidade! / Enquanto em torno cantas, ris e uivas ao léu."

Prólogo de uma peça de teatro, o poema "Veneza", publicado em $\mathbf{O}$ Búzio de Cós, traz à tona uma imagem diferente das duas leituras predominantes da cidade. Aqui ora ela é descrita como herdeira de Babilônia, ora como a cidade na qual florescem os amores. Nesse poema, a cidade não deixa em nenhum momento de se apresentar como um centro de comércio, onde desembarcam navios carregados de jóias, tecidos e perfumes, nem deixa de expor claramente a ação dos mercadores:

\footnotetext{
Dos quatro cantos do mundo

Os navios carregados

Desembarcam no seu cais

Sedas tapetes brocados

Pérolas rubis corais

Colares anéis e pulseiras

E perfumes orientais
}

Cidade é de mercadores

[...] 
Ao encontro dessa leitura do ambiente urbano, La Salette Loureiro, cita o médico e filósofo francês Henri Laborit ao apontar para o nível ao qual as práticas comerciais da cidade reduzem o indivíduo:

A Cidade, ou melhor, a classe que a domina, reduziu tudo, mesmo os valores, ao seu valor de troca. 'Na cidade tudo se compra e tudo se vende: as amizades, as honras, os títulos, os graus e as profissões de fé' (LOUREIRO, 1996, p.29).

Entretanto, num contexto em que a configuração do espaço urbano é regida pela dualidade, Peter Dronke lança mão da perspectiva de Santo Agostinho em torno da dicotomia que tem como fonte original a ideia de Paraíso/Inferno para mostrar uma visão menos trágica da Cidade:

Também $\mathrm{S}$. ${ }^{\text {to }}$ Agostinho, porém, tende a falar de duas cidades, uma abençoada e outra perversa, Jerusalém e Babilónia, que sempre coexistiram na terra e aí estiveram em conflito (1991, p.32).

À luz dessa percepção dual do espaço urbano, ganha fôlego uma outra leitura possível de Veneza na medida em que a cidade revela também ter espaço para o amor - "É também de apaixonados" - e para o encontro de culturas distintas, tanto geograficamente, quanto culturalmente: "E cada dia ali chegam / Persas judeus e romanos / Franceses e florentinos / Artistas e bailarinos". Esses protagonistas, aos olhos de um sujeito poético fascinado, contam e inventam suas histórias numa cidade "sobre a água construída". Aliás, esse elemento não apenas realça a beleza da cidade, servindo-lhe de espelho - "E noite e dia se mira / Sobre a água refletida - como também faz dela "senhora do mar".

A ambivalência que se esconde por trás da imagem sedutora da cidade - misto de fascínio e asco - dará a tônica, nas próximas páginas, de outro perfil de espaço urbano: as cidades babilônicas. Corruptas e corruptoras, elas surgem aos olhos do sujeito poético como um espaço hostil e sombrio. Moldadas pelo homem, essas cidades se assemelham à imagem da "famosa prostituta que corrompia a terra com a sua imoralidade" (Apocalipse 18, p.257).

Não por acaso, esses espaços, na poesia da autora, surgem como ambiente propício a contravenções e toda sorte de atividades degradantes aos 
olhos do sujeito poético, à imagem e semelhança da cidade que, munida de luxo e glória, disseminou sofrimento e tristeza:

- Caiu! Caiu a grande Babilônia! Agora quem vive ali são os demônios e todos os espíritos imundos. Todos os tipos de aves e feras imundas e nojentas vivem nela. Pois todas as nações beberam do seu vinho, o vinho forte do seu desejo imoral. Os reis do mundo inteiro cometeram imoralidade sexual com ela, e os homens de negócio deste mundo se enriqueceram à custa das práticas sexuais sujas da prostituta (Apocalipse 18, p.257).

Ao encontro dessa perspectiva, na obra inaugural da autora, Poesia, 0 poema "Cidade" já apresenta o espaço urbano como sítio de inquietação e de tamanha corrupção, que chega a provocar asco no sujeito poético: "Cidade, rumor e vaivém sem paz das ruas, / Ó vida suja, hostil, inutilmente gasta“. Na passagem em questão, a imagem sonora gerada do vocábulo rumor é enfatizada pelo uso da consoante constritiva sonora /v/, que se sobressai na pronúncia de "vaivém" [também a sibilante /s/ dá ideia de movimento, de agitação, de burburinho]. Ao mesmo tempo, o apelo visual da imagem recai sobre a paisagem urbana conferindo a ela o espectro de um lugar maculado e moralmente condenável.

O contraponto a esse lugar de corrupção irrompe nos três versos seguintes, nos quais a leitura do espaço natural como ambiente de limpidez e liberdade ganha fôlego: "Saber que existe o mar e as praias nuas, / Montanhas sem nome e planícies mais vastas / Que o mais vasto desejo". Na passagem em questão, o espaço almejado pelo sujeito poético apresenta-se como o oposto da realidade vivida por ele.

A limpidez do mar, a nudez das praias, a amplitude das planícies, tudo contrasta com a real condição desse sujeito fadado ao enclausuramento imposto pelo espaço urbano: "E eu estou em ti fechada e apenas vejo / Os muros e as paredes, e não vejo / Nem o crescer do mar, nem o mudar das luas."

Nesses versos, a figura da cidade como espaço de cerceamento é tão incisiva que chega ao ponto de privar o eu poético da própria vida que segue além das muralhas. É justamente a consciência dessa separação que amplia a cisão íntima do indivíduo: 
Saber que tomas em ti a minha vida

E que arrastas pela sombra das paredes

A minha alma que fora prometida

Às ondas brancas e às florestas verdes.

O estado do sujeito poético que vive o paradoxo de uma existência inerte e insípida em meio à vida frenética, barulhenta e agitada da cidade surge como exemplo da condição solitária à qual está fadado o homem moderno, segundo La Salette Loureiro:

[...] o homem moderno é um homem solitário, mesmo no meio da multidão, alienado pelo ritmo 'métro-boulot-dodo' e pela manipulação feita através dos media e da publicidade, controlado por uma classe dominante cujo objetivo máximo é o lucro máximo, vive num ambiente uniforme e monótono, encaixotado em casas iguais (cujas características já apontámos), ruas iguais, rodeado de pessoas iguais (a segregação), respirando muitas vezes um ar envenenado de gases e consumindo ruídos para lá do suportável'. O que, tudo somado, é muito pouco propício ao desenvolvimento humano, nas suas vertentes biológica, psicológica e social, conforme demonstram vários analistas (LOUREIRO, 1996, p.41).

Uma leitura parecida do espaço urbano pode ser identificada no poema "Marinheiro sem mar", publicado na obra Mar novo, que traz a figura de um homem que, fadado a vagar pela cidade, vive a contradição de estar permanentemente à deriva. Em terra firme, ele se vê à mercê da hostilidade, corrupção e solidão do espaço urbano, no qual se encontra perdido e sem rumo. Dessa situação têm-se no mar e na cidade dois elementos-chave no estudo do poema, pois, ao mesmo tempo em que rivalizam entre si, ambos são interdependentes.

Analisando pelo prisma da relação complementar que caracteriza esses dois espaços antagônicos, visto que um precisa do outro para existir, é interessante observar que "Marinheiro sem Mar" remonta ao conceito de união dos contrários por meio da imagem. Sob essa perspectiva, é interessante observar a dualidade que está por trás da própria simbologia do elemento marítimo. "Representação da dinâmica da vida, ele congrega, ao mesmo tempo, duas realidades opostas: imagem da vida e da morte" (CHEVALIER, 2007, p.592). Além do sentido não apenas plural, mas também dual presente na imagem do mar, é interessante ampliar o foco para a leitura do título que, 
por sua vez, forma uma outra imagem permeada pelo paradoxo: um marinheiro destituído do mar. Ora, se a figura do marinheiro só existe em função do mar, a ponto de o segundo vocábulo estar contido no primeiro e no que ele evoca, parece contraditório conceber que o elemento marítimo esteja apartado do marinheiro. Entretanto, essa imagem reflete, ao mesmo tempo, a dualidade que rodeia o humano, esse jogo de oposições presente na própria realidade, conforme defende Octavio Paz.

Épica, dramática ou lírica, condensada numa frase ou desenvolvida em mil páginas, toda imagem aproxima ou conjuga realidades opostas, indiferentes ou distanciadas entre si. Isto é, submete à unidade a pluralidade do real (PAZ, 1982, p. 120).

Seguindo para o primeiro verso, é interessante observar que no poema a harmonia se estabelece por meio das relações de oposição identificáveis no jogo de imagens em contraposição. Ao encontro da análise que Agripina Encarnación Alvarez Ferreira faz da concepção bachelardiana - "Os pólos de ambivalência tocam-se, harmonizam-se, aproximam-se, 'contraem-se' no instante poético [...]" (2008, p.18) -, a perspectiva aterradora da cidade só existe em função da consciência do lugar distante e acolhedor representado na figura do mar: "Longe o marinheiro tem/ Uma serena praia de mãos puras/ Mas perdido caminha nas obscuras/ ruas da cidade sem piedade". O advérbio "longe", que abre a estrofe, sinaliza essa distância, antecipando o conflito do poema.

O emprego do verbo "ter", no primeiro verso, no presente do indicativo, conjugado no mesmo tempo verbal que "caminhar", presente no terceiro verso da mesma estrofe, sugere que duas situações (uma vivenciada junto ao mar e outra, no espaço urbano) ocorrem num mesmo tempo. Apesar disso, tais realidades simultâneas são marcadas por uma relação dualista, reforçada por meio das imagens que compõem um jogo de oposição. Se, de um lado, os termos "serena" e "puras" são vocábulos que sugerem calma e claridade, remetendo à simbologia da pureza e daquilo que é intocado pelo homem, "obscuras" sugere escuridão (trevas). A tensão prossegue nos versos 
subseqüentes da primeira estância, ao apresentar a figura de um homem em conflito, perdido na escuridão das ruas da cidade.

No tocante à primeira estância, ainda convém chamar a atenção para outro aspecto. As quatro últimas letras da palavra "obscuras" (que fecha o terceiro verso) são justamente as que compõem "ruas" (termo que abre o verso seguinte). Quando se considera que o termo "ruas" está contido em "obscuras", a leitura da cidade como um espaço sombrio ganha fôlego: "Mas perdido caminha das obscuras/ ruas da cidade sem piedade".

Paz defende que uma coisa só existe porque existe também o seu oposto. Aqui, é possível alinhar ao poema o princípio da contradição complementária, que aponta para a interdependência existente entre os termos contrários. Nesse sentido, no poema de Sophia em estudo, a cidade como espaço de dor e desespero existe em função do seu inverso: o mar como espaço de júbilo e contentamento. Nessa mesma perspectiva, volte-se a Octavio Paz, para quem "cada termo pode se atualizar em seu contrário, de que depende em razão direta e contraditória" (1982, p.122).

Ao longo da leitura de "Marinheiro sem Mar", é possível identificar essa dualidade que se constrói não apenas pelo choque de palavras em contraposição, mas também por meio de uma relação de correspondência entre elas. Um exemplo disso é o uso de metáforas. Na segunda estrofe, ao afirmar que "Todas as cidades são navios", o eu poético aproxima dois conceitos distintos, "cidade" e "navio", estabelecendo entre eles uma relação de similaridade. Ao estabelecer tal relação a poeta retoma a simbologia que permeia essas duas imagens. Símbolo de estabilidade, a cidade também apresenta leituras antagônicas. Enquanto a psicanálise contemporânea a caracteriza como um dos símbolos da mãe, "[...] com seu duplo aspecto de proteção e de limite", há também o símbolo invertido apresentado por Babilônia, "a anticidade, a mãe corrompida e corruptora que, ao invés de dar vida e bênção, atrai morte e maldição" (CHEVALIER, 2007, p.240).

Apesar de sentidos paradoxais habitarem a imagem da cidade dentro do poema, é possível perceber que essas duas leituras coexistem. Em "Marinheiro sem Mar" a cidade tem realmente caráter de limitação. Aqui, a imagem da mãe que "encerra seus filhos" (CHEVALIER, 2007, p. 239) pode ser transposta para 
o espaço no qual o marinheiro se sente realmente aprisionado, confinado. Ao mesmo tempo, o símbolo invertido da cidade, sítio de perdição e degeneração, se sustenta na leitura do poema, na medida em que esse espaço aparece associado a elementos que reforçam seu aspecto impuro: "Ele dormirá na podridão", lê-se na penúltima estrofe.

Também é interessante considerar que a leitura da cidade como um espaço no qual o indivíduo se vê ameaçado pelo desvirtuamento não se revela vã quando considerado o conceito de navio (embarcação), que remete justamente à ideia de uma travessia difícil. De modo que sobreviver à cidade é justamente a travessia tortuosa à qual o marinheiro é submetido.

Outra forma de manifestação da imagem, a comparação, aparece na terceira estrofe. Já no primeiro verso, "E ele vai baloiçando como um mastro", a figura do marinheiro é aproximada à de um objeto que se caracteriza pela firmeza e resistência. Ocorre que, paradoxalmente, esse símbolo de firmeza está a balançar, ou seja, apesar de toda a sua imponência, encontra-se à mercê do incerto, do instável. Essa imagem do mastro, que assim como tantas outras do poema, congrega sentidos opostos, remonta, mais uma vez, à situação do marinheiro, representado na figura de um sujeito à deriva, rumo ao incerto.

As sombras que nadam no rastro do marinheiro, por sua vez, conduzem a mais uma imagem plural. Geralmente ligado à morte, aquele elemento é, de um lado, o que se opõe à luz. Entretanto, também vale lembrar que as sombras somente existem na luz, interceptada ou entrecortada por algo, o fato é que sem a luz, não há sombra.

Ainda no tocante à pluralidade da imagem, a simbologia da sombra - "a própria imagem das coisas fugidias, irreais e mutantes" (CHEVALIER, 2007, p. 842) - complementa a leitura do marinheiro como um indivíduo perdido em meio às incertezas que permeiam o real. É interessante observar como esse homem está mais à vontade na instabilidade do mar sujeito às ondulações e tempestades - "vai sem aves nem ondas repentinas" - do que superfície sólida e firme do chão da cidade.

A incerteza que acompanha a figura do marinheiro é uma característica que permanece ao longo de toda a tessitura poética de "Marinheiro sem Mar", 
conforme é possível observar nos versos que seguem, e apontam para uma leitura de um homem em crise: "Nas confusas redes do seu pensamento/ Prendem-se obscuras medusas".

Na passagem em questão, o vocábulo "confusas" já sugere incerteza e insegurança. Aliada a essa perspectiva, duas imagens - "redes" e "medusas" convergem para a interpretação do marinheiro como um homem perdido nas tramas do próprio pensamento, sugerindo uma luta com o inconsciente. De um lado, a figura da rede simboliza, na psicologia, os "complexos que entravam a vida interior e exterior, cujas malhas são igualmente difíceis de serem desatadas e desenredadas" (CHEVALIER, 2007, p. 772), leitura que explica a perspectiva do marinheiro como um ser aprisionado nas tramas do próprio pensamento, sugerindo um confronto do eu consigo mesmo.

Tal interpretação tem continuidade, por sua vez, na figura da medusa. Recorrente na criação poética de Sophia, a admiração pelos celenterados ${ }^{9}$ aparece aqui na figura deste ser tentacular, que no poema pode ser lido como o "terror íntimo" que permeia o inconsciente, uma ameaça que paira sobre o indivíduo (CEIA, 1996, p.78). A imagem deste elemento se revela plural na medida em que permite duas leituras. Uma baseada na forma e composição do animal, um ser gelatinoso, pegajoso e tentacular que se prende às redes do pensamento do marinheiro. A outra está ligada à figura mitológica, uma das górgonas: "Cada uma das três irmãs (Esteno, Euríale e Medusa), com serpentes no lugar de cabelos, cujo olhar petrificava todos aqueles que as encaravam" (HOUAISS). Aprofundando esta linha de raciocínio com um olhar restrito à figura da medusa, convém retomar a sua simbologia, que remete às deformações monstruosas da psique, segundo as quais a górgona refletiria a culpa pessoal de um eu que fica petrificado de horror ao se defrontar consigo mesmo (CHEVALIER, 2007).

Já na quinta estrofe: "E sobe por escadas escondidas/ E vira por ruas sem nome/ Pela própria escuridão conduzido/ Com pupilas transparentes e de vidro", tem-se, reforçada, a perspectiva da busca vã, à qual está condenado o marinheiro. As escadas representam o lugar onde alto e baixo, céu e terra

\footnotetext{
${ }^{9}$ Animais invertebrados aquáticos, geralmente marinhos com tentáculos e corpo em forma de pólipo ou medusa. (HOUAISS, 2001, p.1880).
} 
podem se unir (CHEVALIER, 2007). Aqui, onde as escadas funcionariam como uma espécie de ponte, capaz de juntar os opostos, a leitura desse elemento resgata, mais uma vez, uma característica freqüente na poesia de Sophia: a busca pela unidade.

Ao mesmo tempo, tal procura parece fadada ao fracasso desde 0 princípio, uma vez que tais escadas estão escondidas. Assim como as ruas não têm nome, nem claridade o marinheiro tem para se orientar. Ele se encontra perdido num labirinto. Esse espaço aprisionante novamente reforça a condição de um homem sem norte. Tal imagem será resgatada e reiterada na estrofe seguinte, em versos que sugerem o malogro de tudo que era vital para o marinheiro: "Porque ele tem um navio mas sem mastros/ Porque o mar secou/ Porque o destino apagou/ O seu nome dos astros". O último verso, aliás, traz à tona o princípio de desarmonia que paira sobre o marinheiro, à medida que os astros simbolizam o comportamento perfeito e regular (CHEVALIER, 2007, p. 95). É como se, de agora em diante, tudo para ele andasse em descompasso, em desordem. Não por acaso, o marinheiro segue sem rumo: "Porque o seu caminho foi perdido/ O seu triunfo vendido."

Diante das imagens que o condenam e aprisionam, o Marinheiro clama pela liberdade, metaforizada em figuras que se opõem a tudo que permeia o espaço citadino, como a luz e o vento: "E é em vão que ele se ergue entre os sinais/ Buscando a luz da madrugada pura/ Chamando pelo vento que há no cais."

"Símbolo da vida, segundo a visão cristã, a luz remete à ideia de salvação e felicidade" (CHEVALIER, 2007, p.570). Somado a isso, a imagem da madrugada aponta para a claridade que há de vir, haja vista que este é o momento em que o escuro vai gradualmente ficando cada vez mais fraco, cedendo, pois, espaço à luz. Esta vai se tornando cada vez mais forte até o alvorecer. Assim, a madrugada se torna o instante desejado por marcar a passagem da escuridão para a luz; por ser o momento do anúncio do novo, do dia, do sair das trevas. Nesse sentido, convém retomar a simbologia das trevas no antigo testamento para se poder ter uma dimensão ainda maior da ânsia do marinheiro pela "madrugada pura": "As trevas são por corolário, símbolo do mal, da infelicidade, do castigo, da perdição e da morte" (idem, p.570). 
Comumente resgatada nos poemas de Sophia, a temática do vento assume sentidos múltiplos dentro da tessitura poética da autora. Ao estudar alguns elementos freqüentes na criação da poeta, Carlos Ceia (1996) destaca que o vento ora desempenha o papel de mensageiro invisível, sendo aguardado independentemente de trazer notícias boas ou más, ora aparece como uma espécie de agente de equilíbrio, o pacificador, que coloca o poeta em paz espiritual com sua terra. Outras possibilidades de leitura dessa mesma imagem aparecem sob a metáfora da esperança, da liberdade e da mudança, do regresso, da destruição e construção, da resistência, da transgressão e da viagem no tempo (volta ao passado).

Num contexto em que um único termo aponta para significados diversos, é interessante retomar o conceito de Octavio Paz, para quem as palavras são dotadas de certa liberdade materializada em seu caráter plural, que possibilita à linguagem dizer sempre algo mais e além dos dicionários e das gramáticas. Essa característica se dá de tal forma que chega a transcender o próprio pensamento daquele que as escreve:

As palavras se conduzem como seres caprichosos e autônomos. Sempre dizem 'isto e o outro' e, ao mesmo tempo, 'aquele e aquele lá'. O pensamento não se resigna; forçada a usá-las, uma e outra vez a linguagem se rebela e rompe os diques da sintaxe e do dicionário (PAZ, 2003, p. 49) ${ }^{10}$.

Nesse contexto, é interessante observar que as três últimas estrofes de "Marinheiro sem Mar" sintetizam a relação entre imagens que se opõem e complementam. $\mathrm{Na} 12^{\mathrm{a}}$ estrofe, tem-se a negação do mundo almejado pelo marinheiro, composto pela "areia lisa", pelas "medusas" (aqui, como imagem dos seres marinhos, não da figura mitológica), por "conchas" e "corais". Já na seguinte, tem-se a afirmação de seu infortúnio e, ao mesmo tempo, é criada uma imagem que rivaliza com aquela apresentada na anterior: "Ele dormirá na podridão/ E ao Norte e ao Sul/ E ao Leste e ao Poente/ Os quatro cavalos do

10 Tradução livre do seguinte trecho: "Las palavras se conducen como seres caprichosos y autónomos. Siempre dicen 'esto y lo otro' y, al mismo tiempo, 'aquello y lo de más allá'. El pensamiento no se resigna; forzado a usarlas, uma y outra vez el lenguaje se rebela y rompe los diques de la sintaxis y del diccionario" (PAZ, 2003, p. 49). 
vento/ Exactos e transparentes/ O esquecerão". Na passagem acima, convém observar a imagem formada pela relação entre os pontos cardeais e a imagem "cavalos do vento". As quatro direções, dentro das crenças relacionadas à origem da vida, são partes constituintes da "[...] esfera total do espaço cósmico e, simbolicamente, do destino humano" (CHEVALIER, 2007, p.730). Nesse espaço, o mundo saído do caos se organizaria.

Nessa leitura, o mundo tem, na representação do cavalo, a imagem do equilíbrio, já que o seu simbolismo estende-se aos dois pólos do Cosmo, alto e baixo: "O cavalo passa com igual desenvoltura da noite ao dia, da morte à vida, da paixão à ação. Religa, portanto, os opostos numa manifestação contínua". Assim, a leitura do marinheiro como um homem que tem seu destino perdido é reforçada na medida em que o espaço no qual o seu mundo se organizaria é abandonado pelo seu agente de equilíbrio.

Convém, no entanto, observar como, ao mesmo tempo em que trabalha imagens capazes de sustentar realidades opostas, o poema atinge a unidade conjugando elementos que só existem porque um tem ao outro como referência. Nesse sentido, a estrofe final aponta justamente para 0 desequilíbrio causado pela ruptura dessa unidade:

Porque ele se perdeu do que era eterno

E separou o seu corpo da unidade

E se entregou ao tempo dividido

Das ruas sem piedade.

Aqui, se faz presente a ruptura entre o mar e o marinheiro. No segundo verso, o corpo separado da unidade reforça essa interpretação. É justamente nesse ponto que a leitura do marinheiro como um homem em crise se apóia. Longe do espaço que o caracteriza, o marujo surge como um ser sem rumo, perdido, sem identidade. É pertinente observar como esse sujeito poético constrói a imagem do homem contemporâneo. O próprio balanço e o ritmo oscilante do mar se opõem à estabilidade do homem que vive em terra firme. Paradoxalmente, o marinheiro entra em conflito justamente na cidade, num terreno fixo. Mas, relacionando a figura do marinheiro ao contexto da modernidade, é possível estabelecer um paralelo com este homem moderno, 
que só consegue viver no ritmo da insegurança. O ambiente nauseante está na cidade, não no mar.

Na mesma obra na qual foi publicado esse poema-chave no estudo da cidade e do contraponto com esta representado pelo espaço marítimo na poesia da autora, também se destaca outra leitura da cidade babilônica. Em "És tu que estás à transparência das cidades" tem-se a impressão de que o sujeito poético se dirige ao um interlocutor com quem tem intimidade, haja vista que o sujeito poético opta pelo uso do pronome pessoal "tu".

És Tu que estás à transparência das cidades

Vê-se o Teu rosto para além dos bairros interditos

No poema em questão, a menção à cidade se dá de maneira breve. Ainda assim, sua perspectiva aterradora é enfática, haja vista que nesse espaço o mal surge como algo "palpável próximo evidente" na segunda estrofe. Novamente a supressão da pontuação sugere um emaranhado de imagens justapostas, reforçando ainda mais essa perspectiva negativa do espaço urbano:

O mal palpável próximo insistente

Parece tornar-Te evidente.

No poema "Busca", publicado em O Cristo Cigano, a cidade também tem uma presença sutil, haja vista que o texto poético em questão tem como cenário predominante o meio natural, no qual a figura central é um "eu" que vive um paradoxo, à medida que está permanentemente à procura de uma "presença ausente". O oxímoro, que é o máximo do paradoxo, suscita um aspecto-chave no poema: a presença de um sujeito em constante busca de algo que, apesar de existir de fato, aparece sempre como uma ausência para ele:

$$
\begin{aligned}
& \text { Pelos campos fora } \\
& \text { Caminhava sempre } \\
& \text { Como se buscasse } \\
& \text { Uma presença ausente. }
\end{aligned}
$$

A segunda estrofe traz à tona a identidade dessa "presença ausente": a morte. O sujeito poético pergunta onde está seu paradeiro num mundo tão repleto de vida: 
Onde estás tu morte?

Não te posso ver:

Neste dia de Maio

Com rosas e trigo

É como se tu não

Vivesses comigo.

No quarto verso da estância, a referência às rosas - símbolo da "taça da vida" (CHEVALIER e GHEERBRANT, p.788) - e ao trigo, que remete à deusa de fecundidade Démeter, "iniciadora aos mistérios da vida" (p.906), revelam a presença incisiva da vida a ofuscar a existência latente da morte como parte de seu ciclo natural.

Ao mesmo tempo em que admite ter consciência de que a morte é um destino irrefutável e inelutável ao qual o ser humano está fadado, é praticamente impossível para esse sujeito sequer imaginar como ela é, já que a vida a ofusca por completo:

\section{A ti me enviaram \\ És tu meu destino \\ Mas diante da vida \\ Eu não te imagino}

Essa apreensão do real também se dá por meio de sinestesias. No trecho a seguir, o sujeito revela ter sido enviado à morte: "A ti me enviaram / "E sei que me esperas". Entretanto, somente consegue reconhecer a vida. Essa realidade se manifesta através da percepção sensorial, por meio da relação que se estabelece entre a audição e a visão: "Mas só oiço a verde/ Voz das primaveras". Nesse sentido, a quinta estrofe é uma espécie de testemunho da vida, apesar do reiterado ubi sunt, a questionar o "paradeiro" da morte, conforme se lê nos versos que abrem a estância:

\footnotetext{
Onde a tua imagem

Onde o teu retrato

Na manhã tão limpa?

Onde a tua imagem

Onde o teu retrato

Nas tardes serenas

Nos frutos redondos

Nas crianças puras

Nas mulheres criando

Com seus gestos vida?
} 
A cidade surge alguns versos adiante, como uma mera coadjuvante num poema em que o espaço natural predomina. Ainda assim, é pertinente observar como a percepção do sujeito sinaliza um lado mais obscuro do real. A morte chega a aparecer na cidade em raras ocasiões - "É verdade que passas / Pela cidade às vezes / Nos caixões de chumbo" - e, ainda que de forma passageira, deixa seu rastro aterrador, fazendo do espaço urbano, um cenário fúnebre:

\author{
Mas viro o meu rosto \\ Pois não te compreendo \\ És um pesadelo \\ Uma coisa inventada \\ Que o vento desmente \\ Com suas mãos frescas \\ E a luz logo apaga.
}

É nesse sentido que o sujeito faz da cidade o único lugar onde a morte pode realmente ser vista, ainda que siga negando-a, sempre:

\author{
É verdade que passas \\ Pela cidade às vezes \\ Com teu vestido roxo, \\ Entre velas e incenso: \\ Mas eu te renego e o vento te nega \\ Com suas mãos frescas \\ E eu não te pertenço. \\ Meu corpo é do sol \\ Minh'alma é da terra.
}

Um dos aspectos que mais chama a atenção no poema em questão é como a ideia de morte que rege o espaço urbano se afirma através do seu oposto: a vida que perpassa o espaço natural. Tal característica vai ao encontro da perspectiva original de Heráclito de que a tensão é condição imprescindível para a existência das coisas:

É a enfermidade que torna agradável a saúde; o mal, o bem; a fome, a saciedade; o cansaço, o descanso [...] São uniões: o inteiro e o não inteiro, a concordância e a discordância, o consoante e o dissonante e do todo o uno e do uno o todo ${ }^{11}(1963$, p.44).

${ }^{11}$ Tradução livre do trecho:"Es la enfermedad la que hace agradable la salud; el mal, el bien; el hambre, la saciedad; el cansancio, el descanso [...] Son uniones: el entero y 
A percepção do espaço urbano como uma cidade alheia é a tônica do poema "Cidade dos Outros", publicado em Geografia. Tal característica revelase presente desde o título, que serve de chave de leitura para a interpretação do poema, na medida em que esse espaço, conforme observa La Salette Loureiro, tornou-se um ambiente de diluição e dissolução do "eu":

O arquétipo do homem moderno traz um sujeito lançado no turbilhão da vida urbana, sozinho em meio à multidão, lutando contra o peso desse espaço: 'A cidade foi invadida pelas multidões, tornou-se tentacular, ruidosa, apopléptica. Cresceu muito, desmesuradamente. Transbordou. Os centros despovoaram-se, deram lugar aos escritórios, aos Bancos, às Companhias de Seguros. A Burocracia instalou-se. Enredou o Homem num mundo absurdo (ver Kafka - O Castelo). Nasceram as habitações sociais, uniformes, feias, monótonas, 'usine à enfants' reduzindo os homens a 'animaux reproducteus', na perspectiva de M. Ragon. Surgiu a segregação social. A cidade estilhaçou-se. O caos voltou (LOUREIRO, 1996, p.26).

$\mathrm{Na}$ primeira estância do poema, os três adjetivos presentes no verso inicial, potencializados, formam imagens em justaposição cuja plasticidade resulta no retrato do espaço urbano como um ambiente feroz, inóspito, no qual a corrupção aflora:

Uma terrível atroz imensa

Desonestidade

Cobre a cidade

$\mathrm{Na}$ estrofe seguinte, expressões como "murmúrio de combinações" e "telegrafia sem gestos e sem sinais" dão a dimensão de como a degradação do caráter e da honestidade no ambiente citadino se instaura tal qual uma rede, num contexto em que a harmonia entre iguais é tão precisa que "O mal procura o mal e ambos se entendem."

A interpretação de tais versos tem na imagem bíblica da Babilônia sua matriz elementar. Descrita como a grande cidade que domina os reis do mundo inteiro, ela é aquela que, com feitiçaria, "enganou todos os povos da terra", daí

lo no entero, lo concorde y lo discorde, lo consonante y lo disonante y del todo el uno y del uno el todo" (1963, p.44). 
sua configuração, além de "famosa prostituta", como o ambiente no qual a contravenção, os vícios e o mal assomam diferentes níveis da sociedade:

Os reis do mundo inteiro que tomaram parte na imoralidade e na corrupção dela vão gritar e chorar quando virem a fumaça do seu incêndio. Eles ficam de longe porque têm medo de tomar parte no castigo que ela vai sofrer e dizem:

- Ai de você, Babilônia, grande e poderosa cidade! Em apenas uma hora você já foi castigada!

Os comerciantes do mundo inteiro também gritam e se lamentam por causa dela porque ninguém mais compra os produtos deles. Ninguém compra o seu ouro, prata, pedras preciosas e pérolas [...] (Apocalipse 18, p.257)

Nesse ambiente corrompido e corruptor, o sujeito poético admite seu isolamento, daí a percepção do espaço urbano como a cidade alheia aludida no título e no verso que encerra o poema: "E com sabor a coisa morta / A cidade dos outros / Bate à nossa porta".

A identificação entre o ambiente citadino e Babilônia também é a tônica do poema "No deserto" (Geografia), cujo título aponta para significados diversos, mas que, ao mesmo tempo, seguem numa direção comum: a busca. Seja a procura da essência, a busca dos hebreus pela terra prometida e a do Santo Graal, o título remete a um anseio do sujeito poético.

É interessante também a dialética entre interior e exterior que rege a relação do sujeito poético com o deserto. Além disso, "no esoterismo ismaélico, esse espaço simboliza o ser exterior, o corpo, o mundo, o literalismo que a pessoa percorre cegamente, sem perceber o Ser divino escondido no interior dessas aparências”. Outra definição interessante é apresentada por Richard de Saint-Victor e se baseia na ideia de que o deserto é o "lugar da vida eremítica interiorizada" (CHEVALIER E CHEERBRANT, 2007, p. 331).

Quando se considera a concepção que Bachelard tem acerca da imensidão íntima, verifica-se na imagem do deserto a busca por uma imensidão que está no próprio sujeito, num contexto em que o indivíduo anseia a fuga da cidade (espaço restrito) para o deserto (ambiente caracterizado pela imensidão) para se encontrar com a amplitude latente do "eu": "A imensidão está em nós. Está ligada a uma espécie de expansão do ser que a vida refreia, 
que a prudência detém, mas que retorna na solidão" (BACHELARD, 2008, p.190).

É nesse sentido que a cidade surge, ao longo do poema, como um espaço que se contrapõe ao deserto. Nos versos seguintes se verá ainda que o interior do sujeito poético também é cenário de um embate. Quando se fala em "metade", como no primeiro verso, já se vislumbra a ideia de cisão. Logo de início, a imagem que se tem é a de um sujeito poético no qual coexistem dois 'eus', um que cede aos instintos e outro que impõe a vontade sobre os desejos. Mas, apesar da existência dessas duas "metades", aquela orientada pela vontade é justamente a que se impõe, à proporção que o sujeito afirma ter domínio sobre a outra:

Metade de mim cavalo de mim mesma eu te domino Eu te debelo com espora e rédea

No segundo verso, essa postura firme do sujeito para que prevaleça sua vontade é enfatizada pelo emprego do verbo "debelar". Com "espora" e "rédea" seu desejo é derrotado, vencido, extinto, suplantado. E note que se trata de uma "metade" quase selvagem: é o "cavalo" que precisa ser domado com "espora" e "rédea".

Quando se considera uma das acepções do cavalo, que segundo psicanalistas simboliza o psiquismo inconsciente ou da psique não humana "ligado aos grandes relógios naturais, ou ainda, ao da impetuosidade do desejo" (CHEVALIER E CHEERBRANT, 2007, p.203) - entende-se a necessidade desse "eu" de controlar seus impulsos.

A alusão à percepção negativa da paisagem citadina surge na segunda estrofe, na qual ela é descrita por meio da expressão "cidades mortas". Nesse espaço, o sujeito se encontra à mercê da corrupção, da hostilidade e do infortúnio. Nesse sentido, é possível estabelecer um paralelo entre o excerto abaixo e a surpresa do sujeito poético criado por Cesário Verde no poema "A débil" ao se deparar com alguém tão frágil em plena "Babel tão velha e corruptora":

Para que não te percas nas cidades mortas

Para que não te percas

Nem nos comércios de Babilônia

Nem nos ritos sangrentos de Nínive 
("No deserto", Geografia)

Antes de analisar como o ambiente urbano materializado no poema estabelece uma relação com a imagem de Babilônia, convém lembrar que a simbologia da cidade também permite uma relação com a imagem da mãe e seu duplo aspecto de proteção e limite. Por mais que predomine a imagem do espaço propício às perversões e contravenções da grande prostituta antítese de Jerusalém, o espaço urbano no poema em estudo também pode ser visto como um ambiente cerceador.

Considerada essa leitura, é possível identificar na anticidade o perfil de espaço urbano que predomina no poema, até pela própria menção explícita à famosa prostituta: "Para que não te percas / Nem nos comércios de Babilônia". Ao se referir aos negócios do cobiçado centro comercial, que ficou conhecido como a cidade "mãe das repugnantes prostitutas da terra", o sujeito poético expressa sua preocupação em preservar sua integridade, distanciando-se do meio degradante já analisado por La Salette Loureiro:

A bíblia oferece ainda dois modelos de cidade que funcionarão como arquétipo ao longo dos séculos: a cidade corrupta e corruptora, a grande prostituta, Babilónia, mas também Sodoma e Gomorra, todas elas castigadas [...] (LOUREIRO, 1996, p.20).

Nesse sentido, é interessante ainda refletir sobre a estrofe em questão considerando mais essas duas acepções simbólicas acerca de Babilônia:

No plano dos símbolos, Babilônia é a antítese da Jerusalém celeste e do paraíso. Entretanto, de acordo com sua etimologia, Babilônia significa: porta do deus. Mas o deus sobre o qual essa porta se abre, se bem que em certa época tenha sido buscado nos céus, no sentido do espírito, perverteu-se em homem e naquilo que no homem existe de mais vil: o instinto de dominação e o instinto de luxúria, erigidos em absoluto (CHEVALIER E CHEERBRANT, 2007, p.112).

O símbolo de Babilônia não é o de um esplendor condenado por sua beleza, mas o de um esplendor viciado, que a si próprio se condenou ao desviar o homem de sua vocação espiritual. Babilônia simboliza o triunfo passageiro de um mundo material e sensível, que exalta apenas uma parcela do homem e que, consequentemente, o desintegra (CHEVALIER E CHEERBRANT, 2007, p.112). 
Já os "ritos sangrentos de Nínive" surgem como uma referência à cidade conhecida pelos métodos extremamente cruéis de guerrear. Juntas, as duas cidades mortas - Babilônia e Nínive - simbolizam um espaço de corrupção e sofrimento do qual o sujeito poético quer se desvencilhar.

$\mathrm{Na}$ terceira estrofe, o "eu" orienta a metade de sua psique inconsciente para o deserto limpo. Nesse primeiro verso, antes de atentar para a imagem da amplidão do espaço, é interessante observar a parte do corpo à qual ele recorre para isso: o nariz. Segundo Chevalier e Cheerbrant, assim como o olho, "o nariz é símbolo de clarividência, de perspicácia, de discernimento, mais intuitivo que racional” (2007, p.631):

\section{Eu aponto o teu nariz para o deserto limpo Para o perfume limpo do deserto \\ Para a sua solidão de extremo a extremo}

Fazendo uma leitura do poema à luz desses dois termos-chave intuição e racionalidade - é interessante observar como a metade racional e orientada pela vontade do sujeito poético assume a dianteira, impondo-se, inclusive, em campos onde o inconsciente tende a prevalecer. Se o nariz tende para a intuição, a metade racional do eu se encarrega de corrigir isso guiando ele mesmo, arbitrariamente, a percepção de sua outra metade: "Eu aponto o teu nariz para o deserto limpo".

Ainda no mesmo verso, observa-se que tal símbolo de clarividência intuitiva é guiado para o "deserto limpo". Se a imagem do deserto já alude à nudez, no tocante ao vazio de um espaço, a combinação desse substantivo com o adjetivo "limpo" enfatiza ainda mais essa busca da metade racional do sujeito poético ao longo desse espaço de solidão. É importante ressaltar que não se trata de uma solidão qualquer, mas uma imagem da solidão que está atrelada à ideia de pureza, ao essencial de uma existência eremítica que busca a comunhão do indivíduo consigo mesmo. Se na cidade amplamente povoada esse sujeito se perde no labirinto babilônico, no imenso deserto ele busca a comunhão com sua outra metade. De modo que se a cidade é um espaço de cisão, o deserto é lugar de comunhão.

$\mathrm{Na}$ estrofe abaixo, observa-se no sujeito poético um tom mais incisivo e firme para controlar a parte indômita do "eu", a repetição do pronome pessoal "te" nos versos que compõem o dístico já sinalizam. Os verbos, por sua vez, 
todos, sem exceções, são verbos fortes, que sugerem tanto ações vigorosas (dominar, reter, frear), quanto intensas (debelar e combater), e até mesmo extremas (cortar e ferir). De modo que toda a ordenação sintática da estrofe converge para essa intenção de tornar o tom do discurso desse sujeito mais forte, mais enfático e preciso:

Por isso te debelo te combato te domino

$\mathrm{E}$ o freio te corta a espora te fere a rédea te retém

$\mathrm{Na}$ última estrofe, o sujeito traz à tona o porquê de tantos esforços. A imagem do deserto surge sob a égide da liberdade. Nesse local de liberdade, a cisão deixa de existir: "Onde não somos nós dois mas só um mesmo", como se reitera duas vezes:

Para poder soltar-se livre no deserto

Onde não somos nós dois mas só um mesmo

No deserto limpo com seu perfume de astros

$\mathrm{Na}$ grande claridade limpa do deserto

No espaço interior de cada poema

Luz e fogo perdidos mas tão perto

Onde não somos nós dois mas só um mesmo

Observando por este prisma, pode-se dizer que o exterior em Sophia é o espaço transformado pelo homem (do qual a cidade é o expoente maior) e o interior (aquele com o qual o sujeito se identifica) é o meio natural, no poema representado pelo deserto. Pode parecer contraditório, mas o meio natural em toda a sua amplitude pode remeter ao interior do ser, conforme a perspectiva de que "o exterior e o interior são ambos íntimos; estão sempre prontos a inverter-se, a trocar sua hostilidade" (BACHELARD, 2008, p.221).

No terceiro verso, uma característica que merece observação é a sinestesia. A imagem dos astros, conhecida por aguçar a visão, prende 0 sujeito através de outro sentido, o olfato: "No deserto limpo com seu perfume de astros".

Nesse espaço, onde o sujeito poético encontra a comunhão consigo mesmo, convém observar o conjunto de elementos que contribuem para 0 resgate dessa unidade. Os astros, por exemplo, remetem ao ideal de perfeição e ordem das coisas, na medida em que são símbolos do comportamento perfeito e regular. 
A claridade do mundo natural é outra temática recorrente na poesia da autora. "A grande claridade limpa do deserto" é, para a poeta, uma reminiscência da luz do universo natural, diferentemente da luz artificial do espaço urbano, conforme observa Carlos Ceia:

Porque é artificial, a luz da cidade transporta um sopro de desintegração que deixa Sophia indefesa perante essa "queixa cortada'. Esta luz já decadente da cidade não tem já nada a ver com a luz do mundo elemental de Sophia" (CEIA, 2003, p. 110).

Ainda sobre o quarto verso e os dois subsequentes é interessante observar o papel desempenhado pelo vazio:

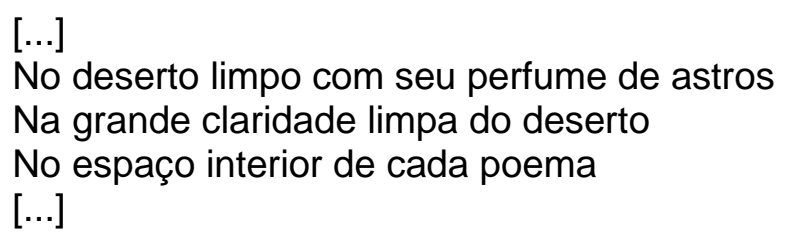

Os três versos remetem a um espaço que se caracteriza pela limpeza (repetida duas vezes). Nota-se ainda a presença da claridade e de elementos que conduzem à imagem de um espaço fechado e inóspito (como o deserto), porém puro e atraente como o poema. Para o sujeito poético e, por extensão, para Sophia, o "espaço interior de cada poema" tem a mesma pureza, limpeza, claridade desse "deserto limpo". Essa ausência de mácula parece ser o primordial, o originário, somente possível ao mundo natural, não transformado pelo homem.

Mas se o deserto representa o espaço utópico da plenitude almejada pelo sujeito poético, o poema surge como uma alternativa possível para que este indivíduo alcance seu intento. O espaço do deserto está para o espaço do poema. Se no deserto o sujeito se realiza utopicamente, no poema ele o faz pela via da linguagem e, ao fazê-lo, emerge do caos recuperando a unidade perdida, conforme se lê nos versos finais:

No espaço interior de cada poema

Luz e fogo perdidos mas tão perto

Onde não somos nós dois mas só um mesmo 
Outra característica da cidade babilônica a se somar às outras já apresentadas é a tônica do poema "Tempo de não", publicado em Ilhas, cujo título já antecipa o tom que vai perdurar ao longo desse texto poético composto por uma estrofe (quarteto) apenas. Logo de início tem-se clara a ideia de que é a negação que rege a percepção do real pelo sujeito poético, a ponto de, no primeiro verso, a pureza (busca recorrente na obra da autora) aparecer associada a um termo que sugere repulsa: "Exausta fujo as arenas do puro intolerável".

O mesmo acontece com outra imagem recorrente nos poemas de Sophia, a dos deuses que agora revelam seu poder de punição: "Os deuses da destruição sentaram-se ao meu lado". Por fim, nos dois versos finais, o contraponto estabelecido entre esse espaço e o mar mostra como uma poesia tão breve pode abrigar um grande poder de síntese: "A cidade onde habito é rica em desastres / Embora exista a praia limpa que sonhei". No tocante a esses versos, mais uma vez, recorre-se à perspectiva original de Heráclito que, desenvolvida por Paz, resulta no conceito de identidade dos contrários, num contexto em que a existência de realidades opostas não implica na supressão de nenhuma delas. Desse modo, os "desastres" da "cidade" coexistem com a "praia limpa" sonhada pelo sujeito poético e, dentro do poema, o antagonismo entre eles os caracteriza, os define melhor à medida que um se afirma no outro.

Na mesma linha, recorre-se a Bachelard para chamar a atenção para a unidade por trás da ideia de ambivalência: "Quando um poema encontra um tom dramático ambivalente, sente-se que é o eco multiplicado de um instante valorizado em que se enlaçam, no coração do poeta, o bem e o mal de todo um universo [..."12 (BACHELARD, 1947 apud; FERREIRA, 2008, p.18-19).

A cidade volta a ocupar um espaço coadjuvante no poema "Barco", publicado em Coral. No texto em questão, a imagem do barco logo de início já remete ao mar, temática predominante no poema:

Margens inertes abrem os seus braços, Um grande barco no silêncio parte.

Altas gaivotas nos ângulos a pique,

\footnotetext{
${ }^{12}$ BACHELARD, Gaston. L'eau et les rêves. Essai sur l'imagination de la matière. Paris: José Corti, 1947.
} 
Recém-nascida a luz, perfeita a morte.

Apesar de ser mencionada apenas uma vez, no último verso da segunda e penúltima estância, a cidade tem um papel-chave. No verso inicial tem-se a partida do barco. E, conforme ele toma distância do cais - intermediário entre a cidade e o mar, no poema em questão -, a cidade surge numa imagem assustadora: "E o seu rosto busca-se emergindo / Do corpo sem cabeça da cidade."

Eis que o afastamento entre barco e cidade é efetivado, de modo que na estrofe final, essa separação remete à liberdade, uma liberdade capaz até mesmo de proezas, como, por exemplo, talhar o que de mais fugidio existe - 0 vento, formando uma bela imagem poética. Num contexto em que a palavra poética é "essencialmente errante e sempre está fora de si mesma" (BLANCHOT, s/d, p. 45), os versos abaixo mostram como é possível ao poeta dar ao objeto real seu duplo imaginário, originando o que Bachelard define como uma "imagem em expansão"13 (BACHELARD, 1971 apud; FERREIRA, 2008, p. 156):

Um grande barco desligado parte

Esculpindo de frente o vento norte.

É interessante analisar o papel do vento nesse verso também a partir da simbologia do ar e sua aproximação com a ideia de leveza, ao passo que os elementos que permanecem na terra remetem ao peso. Relacionada à imagem da liberdade e vigor, a ideia de se "esculpir o vento" alude ao desaparecimento das dimensões e vai ao encontro da perspectiva de Bachelard acerca deste elemento:

Quando tivermos praticado a psicologia do ar infinito, compreenderemos melhor que no ar infinito se apagam as dimensões e que tocamos assim nessa matéria nãodimensional que nos dá a impressão de uma sublimação íntima absoluta ${ }^{14}$ (BACHELARD, 1950 apud; FERREIRA, 2008 p. 25).

${ }_{14}^{13}$ BACHELARD, Gaston. La poétique de la rêverie. 5. ed. Paris: P.U.F., 1971. 14 L' air et les songes. Essai sur l'imagination du

mouvement. 2. ed. 3. réimpression. Paris: José Corti, 1950. 
Além disso, o movimento do barco é apresentado como algo tão imperativo, tão forte - "Um grande barco desligado parte / Esculpindo de frente o vento norte" -, que sugere que, mais do que cortar o vento (o que é comum), o barco é capaz de esculpi-lo - o que faz da embarcação um agente transformador, capaz de dar a imagem que quer ao material esculpido (o vento).

A presença incisiva dos elementos que são da ordem natural, por sua vez, é a tônica de outro perfil de espaço urbano, aquele formado pelas cidades ideais. Permeados pela claridade, pureza e beleza casta das coisas em sua existência imaculada, esses espaços se distanciam da imagem da cidade babilônica para se aproximarem do ideal délfico de cidade que floresce após o apocalipse:

Então vi um novo céu e uma nova terra. [...] E vi a Cidade Santa, a nova Jerusalém, que descia do céu. Ela vinha de Deus, enfeitada e preparada, vestida como uma noiva que vai encontrar com o noivo (Apocalipse 21, p.259).

Na criação poética da autora, já em Mar Novo se tem uma mostra de como esse ideal de espaço citadino se configura. Em "Na cidade da realidade encontrada e amada" esse ambiente aparece regido por tudo que é da ordem do meio natural e traz à tona um sujeito poético que serve de testemunho de um ambiente onde, ao contrário da cidade moldada pelo homem, quem exerce seu domínio é o meio natural. De modo que os próprios elementos criados pelo homem revelam um intenso elo com o primordial, tudo parece passar por um processo iniciático, a exemplo dos muros que, sendo brancos, sugerem o desejo de aproximação com o estado divino:

No apocalipse o branco é a cor da vestimenta dos que 'saíram da grande tribulação, lavaram sua roupa e branquearam-na com o sangue do cordeiro' (CIRLOT, 2005, p.124-125).

$\mathrm{Na}$ estrofe inicial do poema, observa-se que, como um flaneur da cidade délfica, o sujeito se põe a caminhar pelas ruas e presencia uma espécie da celebração do espaço natural. Os versos abaixo se destacam pela plasticidade e apresentam uma percepção do real centrada no aspecto táctil [brisa] e visual, 
que recupera o exato momento do soprar do vento e a alvura essencial dos muros:

Na cidade da realidade encontrada e amada

Caminhei com a brisa pelas ruas

Havia muros brancos e janelas pintadas

Ainda no tocante à alvura dos muros, é interessante recorrer a Bachelard para estabelecer uma relação entre a alvura evocada pela imagem poética dos "muros brancos" e a intimidade onírica que o sujeito busca atingir, num contexto em que projeta na claridade desse espaço a clarividência interior por ele almejada:

E é sempre assim, a imagem poética está sob o domínio de uma qualidade majorada. A brancura das paredes, por si só, protege a cela do sonhador. Ela é mais forte que toda a geometria e vem integrar-se na cela da intimidade (BACHELARD, 2008, p.230).

Somada à imagem dos muros brancos, essa nova configuração do espaço urbano sob a égide da cidade que emerge do apocalipse é reforçada também pela presença da janela, meio através do qual o indivíduo vê o exterior protegido no interior. Considerada um objeto onírico, na medida em que simboliza a apreensão de um mundo em devir, a imagem da janela é parte constituinte de uma realidade totalmente oposta àquela manifestada nas cidades babilônicas. Ao encontro dessa leitura, Agripina Encarnación Alvarez Ferreira analisa a perspectiva bachelardiana deste elemento alinhada à concepção de vastidão:

A janela abre-se para o mundo. Olha, vê, contempla, mas nada diz. Através da janela, o sonhador sonha, medita, indo além da contemplação panorâmica percebendo que mundo é grande [...] (FERREIRA, 2008, p. 109).

É possível observar que, contrariando a eterna busca do indivíduo, ao longo das diferentes épocas literárias, por reter o tempo, tal elemento não só aparece ao alcance do sujeito poético, mas procura por ele: "E o tempo veio ao meu encontro $[\ldots] "$ ". 
Outra inversão se dá na quarta estrofe do poema. No verso de abertura, é possível observar a presença de uma sombra a se erguer das esquinas. Entretanto, enfatizando a aura de pureza que permeia o texto poético, nota-se que o tom escuro e sombrio característico assume outra cor: azul. Quando se considera que azul é a mais profunda e imaterial das cores e que esta remete à ideia do vazio de algo dotado de uma essência virginal, o verso "E as esquinas ergueram as suas sombras azuis" permite uma interpretação desse espaço almejado alinhada à leitura bíblica da cidade pós-apocalipse, que se mantém casta à espera de seu noivo.

A percepção sinestésica dessa paisagem natural e, ao mesmo tempo, citadina se apresenta de forma sutil, nos dois versos finais, nos quais se tem num primeiro momento a percepção pelo olfato e, depois, pela visão: "E do abril dos campos veio um perfume inteiro de searas / E quando abri a porta as estrelas surgiram."

Outro ponto interessante é a forma contundente como o meio natural e os astros se apossam da cidade. O segundo verso da quinta estrofe - "O sol dá lentamente volta às praças e aos quartos" - mostra que o astro maior não apenas percorre os espaços abertos (jardim) como também os fechados (caso do quarto). No tocante a esse verso, é interessante estabelecer uma relação em torno da simbologia do quarto. Ao discorrer sobre esse ambiente, Bachelard lança mão da perspectiva de Blanchot para aprofundar a imagem do quarto como morada íntima do "eu", estendendo-a, por fim, ao próprio leitor sob a égide do fenômeno da imagem poética:

O quarto de Blanchot é uma morada do espaço íntimo, é o seu quarto interior. Participamos da imagem de um escritor graças àquilo que convém chamar de uma imagem geral. Imediatamente singularizamos essa imagem geral. Nós a habitamos, penetramos nela como Blanchot penetra na sua (BACHELARD, 2008, p.231).

Ainda na mesma estância é possível ver que a escuridão da noite surge revestida de azul, afastando-se da imagem das trevas, que lhe é inerente, para se aproximar tanto da ideia de pureza quanto do conceito de luminância, "luz da noite". Daí a dissonância entre a cidade moldada pelo homem - na qual o 
sujeito é "Pela própria escuridão conduzido", leia-se em "Marinheiro sem mar" e as cidades regidas pelo meio natural:

Na cidade da realidade encontrada e amada O sol dá lentamente a volta às praças e aos quartos Para varrer o chão e preparar a noite

Que é redonda azul e atenta

Concluindo essa trajetória do natural em pleno espaço urbano, a penúltima estância traz apenas um verso, o qual é "chave de leitura" de todo o poema, à medida que a cidade almejada pelo "eu" poético tem como porta de entrada uma imagem que de imediato remete ao mar: "E a porta da cidade é feita de dois barcos".

Quando se analisa o verso em questão sob a perspectiva que Gaston Bachelard mantém acerca da porta - considerada pelo filósofo "a própria origem de um devaneio onde se acumulam desejos e tentações, a tentação de abrir o ser no seu âmago, o desejo de conquistar todos os seres reticentes." (2008, p.225) -, ganha ainda mais fôlego a imagem de um sujeito poético que busca reconfigurar o espaço urbano agregando a esse meio características da cidade délfica.

A leitura de que os elementos que compõem o espaço natural moldam o ambiente urbano, aproximando-o do ideal de cidade clara, pura e bela que sucede $\mathrm{o}$ apocalipse ganha mais peso ainda na imagem poética desse verso, à medida que materializa o anseio do sujeito por tornar real esse espaço.

Em outro poema que vai ao encontro dessa perspectiva, "De pedra e cal" (Geografia), tem-se como eixo estratégico o conceito de claridade, a começar pelo título - "De pedra e cal" - a partir do qual a imagem da cal já remete à brancura. Símbolo de um novo começo, a cor branca aparece em diversas passagens do poema, como se a claridade regesse essa cidade retratada pelo sujeito poético. Lá tudo alude ao espaço natural, que novamente parece imperar sobre o ambiente urbano.

Nesse sentido, é interessante observar como tal domínio vai se revelando lentamente, ao compasso do olhar do "eu", que mostra como o meio natural ocupa a cidade por meio do predomínio do branco. Tanto é que ao longo de todo o poema há dez alusões à alvura - três só no primeiro quarteto , referidas em termos como "cal", "sal", "caiado", "brancura" e na própria 
menção direta ao "branco". A presença constante dessa cor na cidade descrita pelo sujeito é reforçada pela retomada da mesma estrutura - "De pedra e cal [...]" - no primeiro e no terceiro verso.

Tal presença está em toda parte. Ligada ao sagrado, a cor branca predomina em toda a cidade. Entretanto, um elemento em especial ainda ameaça a alvura desse ambiente, as figueiras. Apesar de terem sua simbologia associada à ideia de abundância (Chevalier e Gheerbrant, 2007, p. 427), as figueiras, em Portugal, são consideradas a "árvore maldita", já que foi nela que Judas se enforcou depois de ter traído Cristo. Se a cidade tem algumas figueiras, isso pode sugerir que a brancura da cal, por extensão, a pureza, não tenham conseguido eliminar por completo a corrupção, a degradação e todos os pecados que permeiam aquele espaço.

\section{De pedra e cal é a cidade \\ Com campanários brancos \\ De pedra e cal é a cidade \\ Com algumas figueiras}

A presença da cor branca também surge associada à imagem do labirinto nos versos "De pedra e cal são / Os labirintos brancos". Muitas vezes relacionado à condução do homem ao interior de si mesmo ele também remete à presença de alguma coisa preciosa ou sagrada. Mas como o tema central no poema é a cidade, a interpretação mais próxima seria fundada na sua utilização como sistema de defesa nas portas das cidades fortificadas:

Era traçado sobre as maquetes de casas gregas antigas. Tanto num como no outro caso, trata-se da defesa de uma cidade ou da casa, como se localizadas no centro do mundo (CHEVALIER E GHEERBRANT, 2007, p. 427).

Numa sequência em que o branco vai se apoderando de tudo, é interessante atentar para a imagem poética formada pelos dois versos finais da segunda estrofe: "E a brancura do sal / Sobe pelas escadas". A presença das escadas, símbolo que, segundo Juan Eduardo Cirlot, remete à "ascensão, gradação e comunicação entre os diversos níveis da verticalidade" (2005, p.227), potencializa esse domínio do branco, num contexto em que um elemento fundamental que pertence à ordem do mar - o sal - vai se apoderando do espaço urbano. A essa altura, é interessante observar como a 
cidade assume uma configuração positiva à medida que vai sendo tomada por elementos inerentes ao espaço natural e, nesse caso em especial, o mar (sal).

$\mathrm{Na}$ terceira estância, se tem claramente nítido o papel que o predomínio do branco opera no espaço urbano:

\author{
De pedra a cal a cidade \\ Toda quadriculada \\ Como um xadrez jogado \\ Só com pedras brancas \\ Um xadrez só de torres \\ E cavalos-marinhos \\ Que sacodem as crinas \\ Sob os olhos das moiras
}

O emprego do termo "Toda quadriculada" na primeira das duas estrofes acima transcritas para se referir ao ideal de espaço urbano almejado pelo sujeito remete ao formato da cidade redentora, opondo-se à imagem daquela configurada como espaço de corrupção. Além de constar no Apocalipse 21 como a cidade que "era quadrada, pois seu cumprimento era igual a sua largura (p.259)", ela simboliza a esposa, o local de plenitude, conforme observa La Salette Loureiro: "A Jerusalém celeste, geométrica, de forma quadrada, símbolo da estabilidade, cidade de Deus" (LOUREIRO, 1996, p. 20).

A simbologia do xadrez como "representação do mundo manifestado, tecido de sombra e de luz, em que se alternam e equilibram o yin e o yang" (CHEVALIER E GHEERBRANT, 2007, p 966), permite uma leitura fundada na busca pela claridade através do branco. Isso porque, ao ansiar por uma cidade quadriculada "como um xadrez jogado / só com pedras brancas", o sujeito deixa transparecer sua intenção de fugir das trevas simbolizadas pelo preto. Tal característica talvez reflita sua própria batalha interior:

O tabuleiro de xadrez simboliza a tomada de controle, não só sobre adversários e sobre um território, mas também sobre si mesmo, sobre o próprio eu, porquanto a divisão interior do psiquismo humano é igualmente o cenário de um combate (CHEVALIER E GHEERBRANT, 2007, p 967).

Outro aspecto interessante no poema em questão são as torres. Além de remeterem ao simbolismo ascensional e a uma ideia de escala entre terra e céu, também permitem uma analogia com o próprio homem, num contexto em 
que, novamente, o sujeito transpõe para um elemento da cidade a sua busca interior de ascensão e fuga das trevas:

Assim como a árvore se aproxima da figura humana mais que os animais, que avançam com o corpo horizontalmente, assim também a torre é a única forma de construção que toma a vertical como definição. As janelas do último andar, quase sempre grandes, correspondem aos olhos e ao pensamento. Por essa razão reforça-se o simbolismo da Torre de Babel como empresa quimérica, que conduz ao fracasso e ao extravio mental (CIRLOT, 2005, p.573-574).

Nessa cidade, onde o mar revela-se presente, seja na "brancura do sal" a subir as escadas, seja nos "cavalos-marinhos" que ocupam os quadrados de pedras brancas do tabuleiro de xadrez, a alvura estende-se até o chão: "Caminha devagar / Porque o chão é caiado". Nesse sentido, é interessante observar o paralelismo existente entre o poema "De pedra e Cal" e "Marinheiro sem mar", analisado anteriormente no contexto da imagem babilônica da cidade. Assim como no poema publicado em Mar Novo alguns elementos inerentes ao espaço marítimo deslocam-se desse ambiente para o meio urbano assumindo, assim, feições extremamente negativas, materializadas através das imagens de seres tentaculares e sombrios, no poema "De pedra e Cal" esses elementos também se deslocam para o espaço urbano, mas operam uma ação inversa. À medida que migram para a cidade, reconfiguram completamente esse espaço, aproximando-o da variante citadina que emerge do Apocalipse.

Apesar de se manifestar de forma mais sutil, tem-se aqui uma situação semelhante à apresentada no poema "Paisagem", de Baudelaire. O texto em questão apresenta um sujeito poético que busca resquícios do espaço natural no ambiente urbano. Ele não nega "As torres e chaminés, os mastros da cidade", mas nesse ambiente inóspito à vida natural, ele se mantém guiado pelos "vastos céus a recordar a eternidade" à procura dos "Jardins onde a água chora em meio aos alabastros".

A busca por índices do meio natural na paisagem citadina também está presente em "Brasília", publicado em Geografia. No poema, a imagem da cidade erguida pela deusa Athena, que rege a natureza e o mundo humano, é evocada diante da harmonia "ordenada" e "clara" de Brasília. Da mesma forma que a antiga cidade grega foi erguida pela "Deusa da natureza inviolada", a 
jovem cidade permeada pela "essência universal das formas justas" segue apadrinhada pelo espaço natural, que transpõe para os arranha-céus "uma finura delicada de coqueiro".

Esguia como um fuste de palmeira

Sobre a lisa página do planalto

A arquitectura escreveu sua própria paisagem

O Brasil emergiu do barroco e encontrou o seu número

No centro do reino de Ártemis

- deusa da natureza inviolada -

No extremo da caminhada dos Candongos

No extremo da nostalgia dos Candongos

Athena ergueu sua cidade de cimento e vidro

Athena ergueu sua cidade ordenada e clara como um

[pensamento

E há no arranha-céus uma finura delicada de coqueiro

Ainda no tocante ao espaço natural, a plasticidade diante dessa paisagem pode ser identificada no poema "O sol o muro o mar" (Ilhas), no qual é possível identificar uma multiplicidade de imagens poéticas. Aqui, o espaço urbano é apresentado por meio de cidades que se distinguem das demais por uma razão em especial: a ausência do homem. É curioso observar como esse espaço se aproxima da concepção ideal de cidade à proporção que os vestígios da presença humana num tempo remoto vão revelando sua atual ausência.

Já de início tem-se a imagem do "mundo que foi destroçado pelas fúrias" e do papel que a poeta desempenha nesse contexto, à medida que é por meio do "olhar" que se busca reunir tais destroços. Quando se considera a simbologia do olhar baseada no conceito de que ele é uma "barreira defensiva do indivíduo contra o mundo" (CIRLOT, 2005, p. 427), faz sentido a leitura de que é a ferramenta da qual o sujeito poético se utiliza para buscar a unidade perdida, conforme é possível observar no verso inicial do poema: "O olhar procura reunir um mundo que foi destroçado pelas fúrias".

A busca por reter o primordial, tema recorrente da poesia de Sophia, aparece no segundo verso: "Pequenas cidades: muros caiados e recaiados para manter intacto o alvoroço do início". A força da cor azul e sua capacidade 
de desmaterializar as coisas é um dos agentes que ajuda a apagar a presença do homem nesse espaço: "Janelas com as portadas azuis fechadas: violento azul sem nenhum rosto". Ao encontro dessa característica identificada no poema sobre a mais profunda das cores, Chevalier e Gheerbrant observam:

Aplicada a um objeto, a cor azul suaviza as formas, abrindo-as e desfazendo-as. Uma superfície repassada de azul já não é mais uma superfície, um muro azul deixa de ser um muro. Os movimentos e os sons, assim como as formas, desaparecem no azul, afogam-se nele e somem, como um pássaro no céu (2005, p. 107).

Outra característica marcante no poema, a ausência do homem nesse espaço, é retomada ao correr das estâncias. Além do verso já mencionado acima, são muitas as passagens que denunciam a imagem de uma cidade deserta da presença humana. Nostalgia das festas, ausências de rostos e vultos, espaços despovoados e desérticos e as próprias marcas do passado são os únicos vestígios que restaram de uma presença que no tempo atual segue revestida de ausências, conforme é possível observar nos versos a seguir:

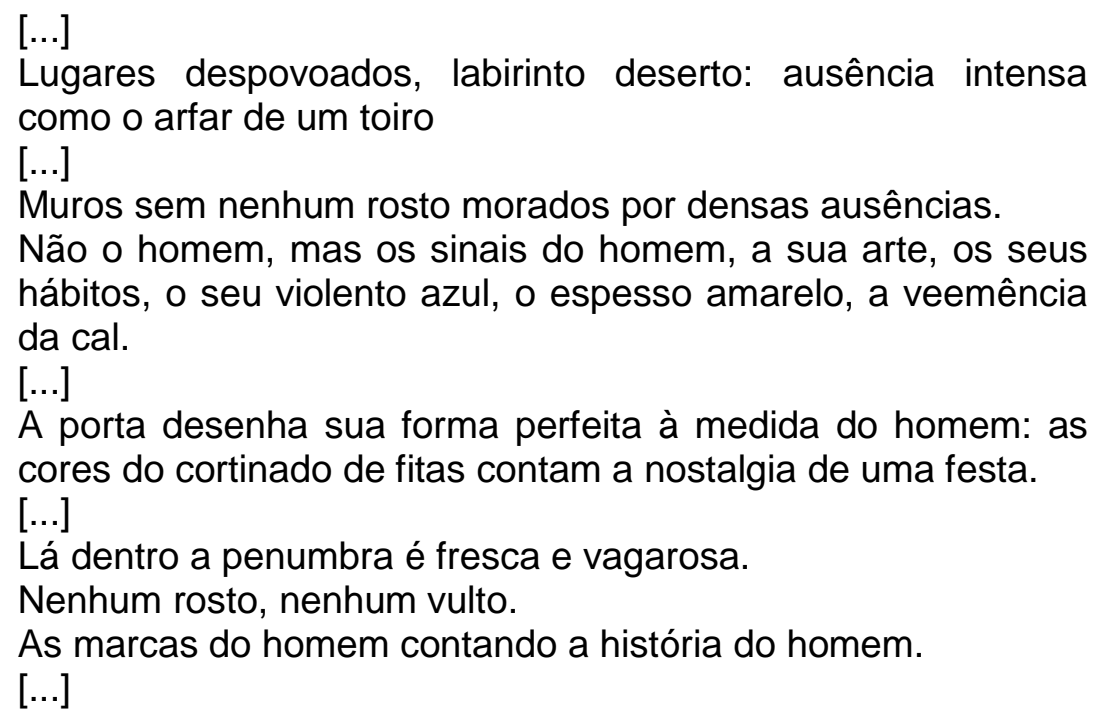

Os excertos extraídos de "O sol o muro o mar" contrapõem-se a vários poemas analisados anteriormente no contexto das cidades babilônicas. Enquanto as cidades que florescem do apocalipse são permeadas por "lugares despovoados", "desertos" e "ausências intensas", o espaço retratado no poema "Cidade" (Poesia) é marcado pelo "vaivém sem paz das ruas". Da mesma 
forma, desfilam "sedas e perfumes" ao longo das "grandes arquiteturas" dos versos de "Cidades e ciladas" (Navegações).

Longe dessas "pequenas cidades de muros caiados" também está o retrato do espaço urbano presente na "Ode Triunfal" entoada pelo heterônimo pessoano Álvaro de Campos, com sua rica galeria de perfis de indivíduos e tipos sociais:

Hé-la as ruas, hé-la as praças, hé-la-hô la foule!

Tudo o que passa, tudo o que pára às montras!

Comerciantes; vadios; escrocs exageradamente bem vestidos; Membros evidentes de clubs aristocráticos;

Esquálidas figuras dúbias, chefes de família vagamente felizes [...]

Tudo que passa, tudo que passa e nunca passa!

(“Ode Triunfal", Poesia completa de Álvaro de Campos)

Voltando à análise do espaço desabitado no poema de Sophia Andresen, é importante observar como, à medida que a ausência do homem vai se estruturando, o retrato e uma vida simples vai sendo desenhado: "muro de taipa", roupa a secar no chão, tinta das paredes que desbotam são elementos que apontam para essa leitura. Acrescenta-se ainda a presença do meio natural na imagem do "chão verde":

Muro de taipa que devagar se esboroa - tinta que se despinta - porta aberta para o pátio de chão verde: soleira do quotidiano onde a roupa seca e espaço de teatro.

Outro ponto que remete à configuração desse espaço como um anseio do sujeito poético de recuperar a cidade primordial se faz presente por meio da presença onírica, que é levemente insinuada, novamente através da menção à cor azul. No verso a seguir, o olhar sobre o desgaste do muro submetido à ação do tempo revela um alto teor pictórico, na medida em que reconstrói a imagem poética do próprio céu: "Muro branco que se descaia e azula irisado de manchas nebulosas e sonhadoras." Nesse sentido, acerca da simbologia do azul, Chevalier e Gheerbrant esclarecem:

Imaterial em si mesmo, o azul desmaterializa tudo aquilo que dele se impregna. É o caminho do infinito, onde o real se transforma em imaginário. 


\begin{abstract}
$[\ldots]$ Claro, o azul é o caminho da divagação, e quando ele se escurece, de acordo com sua tendência natural, torna-se o caminho do sonho. O pensamento consciente, nesse momento, vai pouco a pouco cedendo lugar ao inconsciente, do mesmo modo que a luz do dia vai se tornando insensivelmente a luz da noite, o azul da noite (p.107).
\end{abstract}

Na segunda e última estância, observa-se uma espécie da celebração do ambiente natural configurado pela ausência do homem. Até mesmo a figura do muro, a despeito de sua simbologia fundada na ideia de "detenção" e "limite" (CIRLOT, 2005, p.396), está longe de ser um meio de confinamento: "No promontório o muro nada fecha ou cerca". Tal verso mostra como, ao contrário da cidade corrupta e corruptora, na qual o sujeito se sente constantemente enclausurado e encerrado, leia-se o poema "Cidade" (Poesia) - "E eu estou em ti fechada e apenas vejo / Os muros e as paredes e não vejo / Nem o crescer do mar nem o mudar das luas" -, a cidade délfica almejada não encerra, não prende o sujeito poético. Da mesma forma, a cidade descrita no Apocalipse 21, que apresenta um novo Céu e uma nova Terra, tem suas portas abertas o tempo todo, constituindo um espaço de liberdade: "Os portões da cidade estavam sempre abertos o dia inteiro. Não se fecharão porque ali não haverá noite" (p.260).

Extenso, o muro reaparece no verso subsequente como um elemento que se interpõe à escuridão provocada pela "sombra do rochedo" e à claridade das "lâmpadas das águas". A imagem, proporcionada pelo reflexo do brilho do sol sobre as águas (que lembram escamas a brilhar), aliás, é retomada mais de uma vez na estrofe em questão:

No promontório o muro nada fecha ou cerca.

Longo muro branco entre a sombra do rochedo e as lâmpadas das águas.

No quadrado aberto da janela o mar cintila coberto de escamas e brilhos como na infância.

$[\ldots]$

No tocante aos dois últimos versos do trecho selecionado da estrofe acima - "No quadrado aberto da janela o mar cintila coberto de escamas e brilhos como na infância." - é interessante atentar para dois aspectos. O 
primeiro deles é o mar, que, nas malhas do texto poético, a despeito da sua imensidão, cabe na moldura de uma janela. Mas quando se considera a perspectiva de Bachelard, segundo a qual toda doutrina do imaginário é obrigatoriamente uma filosofia do excessivo e que "toda imagem tem um destino de engrandecimento", o mar contido no "quadrado aberto da janela" deixa de ser uma propriedade do imaginário para se revelar uma verdade, a realidade poética. (BACHELARD, 2008, p.213-214). Tais versos, aliás, remetem aos de Carlos Drummond de Andrade, no poema composto por uma estrofe intitulado "O mundo é grande", no qual se tem uma gradação que parte da imensidão do mundo para o "breve espaço de beijar", que apesar de efêmero, pode conter o amor.

\footnotetext{
O mundo é grande e cabe nesta janela sobre o mar

O mar é grande e cabe na cama e no colchão de amar

O amor é grande e cabe no breve espaço de beijar.
}

Voltando ao poema de Sophia, o segundo aspecto a ser observado acerca da última estrofe é a imagem poética da figura do mar a cintilar "coberto de escamas e brilhos como na infância". Quando se considera a perspectiva de Bachelard, segundo a qual "os verdadeiros bem-estares têm um passado" (2008, p. 25), é possível estabelecer uma relação de afinidade que o sujeito estabelece ao se deparar com uma cena presente que the remete a alguma memória da infância.

Por fim, os versos que encerram a estrofe e o poema reapresentam elementos inerentes ao espaço natural - mar, luz e a cor azul - compondo um cenário associado à configuração de um espaço sagrado:

$[\ldots]$

O mar segue seu radioso sorrir de estátua arcaica.

Toda luz se azula.

Reconhecemos nossa inata alegria: a evidência do lugar sagrado.

Tal perspectiva novamente conduz à imagem da cidade sagrada presente no Apocalipse 21: "Ele (o Espírito de Deus) me mostrou Jerusalém, a Cidade Santa, que descia do céu e vinha de Deus, brilhando com a glória de 
Deus" (p.259). Da mesma forma, também está vinculada à imagem do sagrado o espaço urbano presente na tradição grega:

A cidade também está ligada à morada dos deuses, a história aponta que a cidade é o local dos templos, como na cidade helénica, que tinha na Acrópole a morada dos deuses, de modo que ela assume, assim, desde sempre, um caráter religioso, uma função sagrada (LOUREIRO, 1996, p.22).

Kacem Basfao, ao discorrer sobre a cidade ideal na tradição marroquina, observa ainda:

A Cidade Ideal da Tradição é um sonho utópico cujo modelo de base é a Mesquita, verdadeira casa comum dos crentes: ou seja, um volume construído, urbano, encerrando uma imensa esplanada central que serve de local de oração (ou compreendendo a mesquita no seu centro). Esta Cidade Ideal, homogénea e monolítica, construída sobre o modelo de uma figura geométrica perfeita, simboliza a aspiração do grupo de formar um Todo único e uno. O valor padrão é aqui o Colectivo, a comunidade. (1991, p. 218)

A amplidão que permeia a paisagem natural também é a tônica do último poema alusivo às cidades délficas escrito por Sophia: "Princípio de verão", publicado em Ilhas, e composto por uma estrofe (um quarteto).

No verso inicial, é possível identificar a preferência desse sujeito pelos vastos espaços, endossada, aliás, pela aliteração que se faz presente pela repetição da consoante "l": "Largos longos doces horizontes".

O tom pictórico é outra característica que pode ser identificada. No segundo verso, tem-se a apreensão do exato momento do poente: "A desdobrada luz ao fim da tarde". Ao encontro dessa característica, cite-se Jorge Luiz Antonio, que observa as similaridades entre o ofício do poeta e o do pintor:

Olhar a realidade e descrevê-la como o poeta a vê representa uma atitude que se assemelha ao procedimento de um pintor. Apresentar uma série de aspectos da realidade de forma até exaustiva é buscar, é mostrar uma observação singular e, ao mesmo tempo, permitir ao leitor que ele forme um panorama, um quadro, um flagrante. (ANTONIO, 2002, p.61) 
A afinidade do sujeito poético com esse espaço segue presente no verso seguinte, conferindo uma atmosfera oposta à paisagem urbana tradicional: "Um ar de praia nas ruas da cidade". Ao transpor o ambiente marítimo representado pela imagem da praia para o espaço citadino, o sujeito poético revela sua ânsia por navegar além do mar de concreto em busca da cidade délfica, que constitui o terceiro perfil de cidade identificado na obra poética da autora.

Considerando o que foi dito até aqui pode se dizer que a configuração do espaço urbano nos poemas de Sophia de Mello Breyner Andresen transcende a percepção estritamente negativa da cidade que poderia vir a ser feita numa análise superficial do tema. Num contexto em que a imagem poética se caracteriza pela pluralidade de sentidos, foi possível identificar ao estudar esse aspecto em pormenor que a percepção babilônica desse espaço não é a única possível. Com uma presença incisiva na criação poética da autora os outros dois perfis de cidade - as sedutoras, dotadas de magnetismo, e as délficas que florescem do Apocalipse - permitem uma leitura mais ampla de como a percepção que o sujeito poético faz do espaço urbano tem no ambiente natural, e em especial no mar, um ponto de referência determinante. 


\section{Conclusão}

Autora de uma obra norteada pelo olhar atento a todas as vicissitudes do mundo que a cerca, Sophia de Mello Breyner Andresen traz em sua criação poética a marca de uma íntima relação com o real. Dele se desprendem antagonismos e convergências, cisões e unidades. Da harmonia grega ao elo rompido com um tempo mítico, da afinidade com o mundo natural ao caos do meio moldado pelo homem, até chegar ao tema central do presente trabalho, uma leitura do espaço urbano e de como ele se relaciona com o mar em alguns poemas, os capítulos iniciais da discussão deram um panorama da criação da poeta percorrendo as diferentes vivências que o real assume em sua tessitura poética.

Desse modo, o primeiro capítulo da discussão, "A poética de Sophia", ao apresentar um panorama de sua obra, revelou de que forma o real se apresenta como uma mescla de esplendor e dor. Se as imagens poéticas que remetem a Grécia se aproximam do espaço natural à medida que resgatam a ideia de um tempo harmonioso em que o homem se encontrava em perfeita sintonia com os deuses e com o universo, a cisão muitas vezes contemporânea ao presente experimentado pelo sujeito acaba revelando um mundo sombrio, corrompido pelos vícios e no qual o indivíduo sobrevive como um exilado, condenado à solidão.

Nesse sentido, o capítulo seguinte da discussão, "Espaço natural e a identidade do sujeito" mostrou que a afinidade com esse ambiente puro e imaculado pode ser a forma encontrada para alcançar a própria purificação. Condenado a viver num mundo hostil e corrompido, esse sujeito encontra na fonte a renovação; no ir e vir do "mar azul e branco" e das "luzidias pedras", a volta "à praia inicial" de sua vida; nos espaços "lisos", como o deserto, o ambiente no qual tudo se desenvolve de forma contínua e harmônica, alcançando, assim, a liberdade tão almejada pelo ser. Não por acaso, foram identificados poemas em que o sujeito, proporcionalmente à identificação que estabeleceu com o meio, tornou-se parte dele, leiam-se os versos de "Um dia" (Dia do mar) - "Um dia mortos, voltaremos / A viver livres como os animais / E mesmo tão cansados floriremos / Irmãos vivos do mar e dos pinhais." 
Em muitos casos, na contemplação dos grandes espaços naturais, como o deserto e o mar, observou-se a procura pela imensidão como uma inclinação pela vastidão que habita o próprio "eu". Exemplo disso é o poema "Foi no mar que aprendi", publicado em 0 búzio de cós, em que a menção ao "longo espraiar das mãos na espuma" remete a uma tentativa de alcançar a comunhão fazendo do meio natural uma extensão do próprio ser. E não é por acaso que nesse meio tão hospitaleiro, o sujeito encontra resquícios da mítica Grécia: "Por isso nos museus da Grécia antiga / [...] / respiro melhor como na praia".

Contrapondo-se a esse ambiente de plenitude no qual o mar figura como o elemento essencial, o espaço transformado pelo homem surge como um lugar corrompido e sombrio, no qual o indivíduo na maioria das vezes surge como um ser exilado, sozinho. Desprovido de identidade própria, ele se encontra abandonado à própria sorte: "Eu me perdi na sordidez do mundo" (Geografia). A percepção negativa do meio moldado pelo homem estende-se até mesmo a momentos em que elementos típicos do meio natural, como a claridade e a luz, deslocam-se para o espaço habitado pelo homem. Eis que nessas horas, a força do ambiente corrompido se sobressai e até a alvura do branco é "desolada" e "suja" e a "luz é cinza", leia-se em "O hospital e a praia" (Livro sexto).

Os aspectos observados nesses dois primeiros capítulos da discussão são elementares para a leitura que entra em cena na terceira parte desse estudo, "Mar de concreto: uma leitura da cidade e de sua relação com o mar nos poemas de Sophia Andresen", onde o meio moldado pelo homem tem na cidade sua expressão maior, do mesmo modo que o ambiente natural encontra no mar seu tema mais marcante.

A hipótese inicial de que a cidade era apresentada como espaço de confinamento, dor e solidão para o sujeito poético e o mar, de júbilo, liberdade e realização revelou-se muito aquém da verdadeira dimensão que esse espaço assume na obra da autora no decorrer da discussão. Dos 22 poemas que compõem o corpus - lembrando que nessa seleção foram incluídos apenas os poemas do capítulo em questão, por falarem estritamente da cidade, não constando, desse modo, os analisados nos capítulos anteriores -, o estudo pormenorizado da variante citadina na criação poética da autora deu origem a 
três perfis distintos de espaço urbano: as cidades sedutoras, as babilônicas e as pós-apocalípticas.

Ocupando um papel intervalar, espaço de prazeres e desventuras, as cidades sedutoras se destacam pela atração que exercem sobre o sujeito poético. Ao longo da análise, observou-se que, sob o fascínio das luzes e sedas, o sujeito poético muitas vezes se sentia também como um ser alheio perdido nos fulgores daquele ambiente. Portadoras de um magnetismo que as aproximava da lua - "Magnéticas e fundas como luas" ("Há cidades acesas na distância", Poesia), as cidades de Sophia, quando comparadas a esse astro, dialogam com a leitura que autores como Álvares de Azevedo e Alexandre Herculano fazem da lua. Nos versos da terceira parte do poema "Spleen e charutos", intitulada "Vagabundo", o poeta da segunda geração do romantismo brasileiro faz uma referência à imagem inalcançável desse astro: "Canto à lua de noite serenatas". Já Alexandre Herculano, no poema "A arrábida", por sua vez, faz uma alusão ao seu magnetismo sedutor: "Da Lua - astro de paz, astro que chama / Os olhos para o céu [...]".

Ao mesmo tempo, também se constatou que a mesma dualidade que existe sob a égide do símbolo lunar também habita o espaço urbano, afinal se as luzes artificiais da cidade assumem um quê de fascínio enganoso aos olhos do sujeito poético, a luz da lua também não passa de um mero reflexo do sol, de modo que ambas resplandecem um esplendor falseado exemplificado nas cidades "luzidias" e "magnéticas" ("As cidades" / Dia do mar).

Outro aspecto que já sinaliza a imperfeição desse ambiente é o desconforto do sujeito poético nesse meio de luzes e fulgores, conforme foi possível observar na análise de versos como os de "Nocturno da Graça", publicado em Mar novo, onde se lê: "Negra cheia de luzes brilha a cidade alheia". Esse estranhamento entre o sujeito e o espaço urbano identificada na poética de Sophia também perpassa versos de outros poetas como Baudelaire - "certa manhã na rua triste e alheia".

A sinestesia revela-se outro agente de atração e repulsa perpetrado pela cidade. Os nardos que "matam" o sujeito poético "de perfume" dos versos de "Há cidades acesas na distância" remetem justamente a essa perspectiva dual inerente à concepção da imagem poética que tem no espaço urbano um de seus exemplos mais intrigantes. 
Para além da cidade e sua mescla de pânico e sossego, entram em cena as cidades babilônicas. Espaços de corrupção, degradação, hostilidade e abandono, esses ambientes permitem uma analogia com a "famosa prostituta que corrompia a terra com a sua imoralidade" (Apocalipse 18, p.257).

Lugar de vendas e trocas, esse ambiente propício às perversões e contravenções surge como uma antítese de Jerusalém em muitos casos, conforme se pode observar no poema "No deserto" (Geografia), no qual o interlocutor do sujeito poético é advertido para não se perder "nos comércios de Babilônia", numa referência direta ao cobiçado centro comercial.

Um aspecto que ganhou ainda mais profundidade nessa leitura foi a visão desse espaço como um ambiente alheio, à medida que o sujeito poético não o reconhece como seu. O poema "Cidade dos outros", publicado na mesma obra, já a partir do título, mostra como o "eu" não se identifica com esse meio e está longe de compactuar com a "atroz" e "imensa" desonestidade que "cobre a cidade".

Ambiente do "mal palpável próximo insistente" ("És tu que estás à transparência das cidades" / Mar Novo), a cidade em muitos poemas analisados nessa parte da discussão foi apresentada como um espaço sombrio e escuro, leiam-se os versos de "Marinheiro sem mar", poema publicado em Mar novo: "Mas perdido caminha das obscuras/ ruas da cidade sem piedade".

Por falar nesse poema em especial, é interessante observar que de tão intensa, essa percepção negativa do espaço urbano é capaz de corromper até mesmo elementos inerentes ao ambiente marítimo, conhecidos por representar o outro extremo dessa perspectiva aterradora da cidade. De modo que "medusas", "polvos", "peixes" e demais elementos do mar ao se deslocarem para a cidade, assumem feições assustadoras.

Inversão semelhante, porém numa ação oposta, se dá no poema "De pedra e Cal" (Geografia). À medida que migram para a cidade, os elementos tipicamente marítimos reconfiguram completamente aquele espaço, aproximando-o da variante citadina que emerge do Apocalipse, terceiro e último perfil de espaço urbano apresentado na discussão. Caracterizadas pela beleza e pela claridade, em contraponto à escuridão das cidades babilônicas, suas variantes délficas revelam-se espaços de bem-aventurança para o sujeito 
poético. Talhadas pelo meio natural, elas são dotadas de uma harmonia virginal.

As semelhanças com a cidade do Apocalipse 21 estão em vários aspectos, vão desde o formato quadriculado - "De pedra e cal a cidade / toda quadriculada" - até a vastidão inerente a esse espaço de "largos longos doces horizontes" ("Princípio de verão", Ilhas). Se na cidade herdeira de Babilônia o sujeito poético está condenado ao "rumor "e ao "vaivém sem paz das ruas", na variante délfica, o bater dos sinos traz "uma paz de convento" ("Nocturno da Graça" ( Mar novo); da mesma forma, a percepção nauseante do "eu" que se põe a vagar pela selva urbana herdeira de Babilônia não é a mesma que acomete aquele que desfruta o "perfume inteiro de searas".

Ao colocar no centro da discussão a análise do espaço urbano, o estudo em questão acabou não apenas trazendo à tona as diferentes implicações que esse espaço adquire na obra de Sophia Andresen, como também comprovou o contraponto representado pela imagem do mar nessa criação poética. Se nas cidades babilônicas o espaço marítimo é o refúgio para o sujeito poético submerso numa realidade caótica, leia-se poemas como "Marinheiro sem mar" e "Tempo de não" (Ilhas), naquelas que sucedem o Apocalipse, o espaço marítimo surge como um dos principais expoentes da "Cidade da realidade encontrada e amada" (Mar novo). De modo que, na alternância de retratos sombrios e claros, aterradores e oníricos, aprisionantes e libertadores da cidade, permanece inalterada a percepção do espaço marítimo como um ambiente de júbilo e contentamento para o sujeito poético. 


\section{Referências Bibliográficas}

\section{Corpus literário}

ANDRESEN, Sophia de Mello Breyner. Dia do mar. Lisboa: Caminho, 2003. . Geografia. Lisboa: Caminho, 2004.

. Ilhas. Lisboa: Caminho, 2004.

. Livro sexto. Lisboa: Caminho, 2003.

. Coral Lisboa: Caminho, 2003.

Mar novo. Lisboa: Caminho, 2003.

. Navegações. Lisboa: Caminho, 2004.

. Poesia. Lisboa: Caminho, 2005.

. Búzio de cós. Lisboa: Caminho, 2004.

. O Cristo cigano. Lisboa: Caminho, 2005. 


\section{Referências Bibliográficas}

ALEGRE, M. Perto da pulsação inicial. Jornal de letras, artes e idéias, Lisboa, n.749, p.9, jun.1999.

ALI, Said. Versificação portuguesa. São Paulo: Edusp, 1999.

AMARAL, Fernando Pinto. A aliança quebrada. Jornal de letras, artes e idéias, Lisboa, n.749, p7, jun.1999.

ANDRESEN, S. de M. B. "O poema é outra forma de conhecer". Jornal de letras, artes e idéias, Lisboa, №709, p.6-8, dez.1997. Depoimento a Ricardo de Araújo Pereira.

.Escrevemos poesia para não nos afogarmos no cais. Jornal de letras, artes e idéias, Lisboa, ano I, №26, p.4, 1982.

Moraes Editores, 1977, p.77-80.

Poesia e revolução. 0 nome das coisas. Lisboa: Sophia de Mello Breyner Andresen fala a Eduardo Prado Coelho. ICALP - Instituto de Cultura e Língua Portuguesa, Lisboa, p. 60-79, 1987.

Poesia e realidade. Colóquio / Letras - Revista

de artes e letras, Lisboa, n. 8, p.53-54, Abr.1960.

;Vilma Arêas (Org.). Poemas Escolhidos. São

Paulo: Companhia das Letras, 2004.

ANTONIO, Jorge Luiz. Cores, forma, luz, movimento: a poesia de Cesário Verde. São Paulo: Musa/FAPESP, 2002.

APOLONIA, Maria Ascensão Ferreira. A memória da expansão ultramarina portuguesa em navegações de Sophia de Mello Breyner Andresen. Tese (Doutorado em Literatura Portuguesa) - Faculdade de Filosofia, Letras e Ciências Humanas, Universidade de São Paulo, São Paulo, 2006. 
Portuguesa) - Faculdade de Filosofia, Letras e Ciências Humanas, Universidade de São Paulo, São Paulo, 1988.

ASSOCIAÇÃO BRASILEIRA DE NORMAS TÉCNICAS. NBR 6023: informação e documentação: citações em documentos: apresentação. Rio São Paulo, 2009.

BACHELARD, Gaston. A poética do espaço. Tradução de Antonio de Pádua Danesi. São Paulo: Martins Fontes, 2008. (Coleção Tópicos).

BARRENTO, João. O Espinho de Sócrates - expressionismo e modernismo. Lisboa: Editorial Presença, 1987.

BASFAO, K. Arquitetura e civilização, tradição e modernidade no Magrebe. In: CENTENO, Y. A simbólica do espaço: cidades, ilhas, jardins. Lisboa: Estampa, 1991

BAUDELAIRE, Charles. As flores do mal. Tradução de Ivan Junqueira. Rio de Janeiro: Nova Fronteira, 2006.

2002.

Sobre a modernidade: São Paulo: Paz e Terra,

BENJAMIN, Walter. A modernidade e os modernos. Tradução de Heindrun Krieger Mendes da Silva, Arlete de Brito e Tania Jatobá. Rio de Janeiro: Biblioteca Tempo Universitário, p.1975.

- O conceito de crítica de arte no romantismo alemão. Tradução de Márcio Seligmann-Silva. São Paulo: lluminuras, 1999.

BETHENCOURT, F. A Simbólica do Espaço nos Romances de Cavalaria. In: CENTENO, Y. A simbólica do espaço: cidades, ilhas, jardins. Lisboa: Estampa, 1991.

Bíblia Sagrada: Nova tradução na linguagem de hoje. Barueri: Sociedade Bíblica do Brasil, 2000.

BLANCHOT, Maurice. El espacio literario. Tradução de Vicky Palant e Jorge Jinkis. Buenos Aires: Editorial Paidós, s/d.

BLOOM, Harold. A angústia da influência - uma teoria da poesia. Tradução de Arthur Nestrovski. Rio de Janeiro: Imago, 1991.

BUENO, Alexei. Mar único de Sophia, visual e musical. O globo, Rio de Janeiro, 132004.20 Disponível 2007 http://www.revista.agulha.nom.br/bue2.html. Acesso em: 8 Out. 2007. 
BUESCU, Helena Carvalhão. Cristalizações: fronteiras da modernidade. Lisboa: Relógio d' Água Editores, 2005.

CALVINO, Italo. Seis propostas para o próximo milênio. Tradução de Ivo Barroso. São Paulo: Companhia das Letras, 2007.

CAMÕES, Luís de. Os Lusíadas. Rio de Janeiro: Nova Fronteira, 1993.

CEIA, Carlos. Iniciação aos mistérios da poesia de Sophia de Mello Breyner Andresen. 1 $\stackrel{\text { a }}{\mathrm{e}}$ ed. Lisboa: Vega, 1996.

. Monólogo Crítico-Nos 50 anos de vida literária de Sophia de Mello Breyner Andresen. Colóquio / Letras, Lisboa, n. 132-133, p.183-187, Abr.- Set. 1994.

Sophia de Mello Breyner Andresen. Lisboa: Vega, 2003.

CENTENO, Y. Os Jardins de Mozart ou as Metamorfoses da Árvore da Vida. In: ; A simbólica do espaço: cidades, ilhas, jardins. Lisboa:

Estampa, 1991.

CHEVALIER, J; Gheerbrant, A. Dicionário de símbolos. Tradução de Vera da Costa e Silva, Raul de Sá Barbosa, Angela Melim e Lucia Melim. 21. ed. Rio de Janeiro: José Olímpio, 2007.

CIRLOT, Juan Eduardo. Dicionário de símbolos. Tradução de Rubens Eduardo Ferreira Frias. São Paulo: Centauro, 2007.

COELHO. Eduardo Prado. Sophia - a lírica e a lógica. Colóquio / Letras, Lisboa, n. 57, p.20-35, set. 1980.

COMPAGNON, Antoine. O demônio da teoria - literatura e senso comum. Tradução de Cleonice Paes Barreto Mourão e Consuelo Fortes Santiago. Belo Horizonte: Editora UFMG, 2006.

COSTA, Maria Velho da. Perdemos a menina do mar. Jornal de letras, artes e idéias, Lisboa, n.881, p.5, 1982.

CRUZ, G. O real absoluto. Jornal de letras, artes e idéias, Lisboa, №709, p.9, dez.1997. 
CUNHA, António Manuel dos Santos. Sophia de Mello Breyner Andresen: mitos gregos e encontro com o real. Lisboa: Imprensa Nacional-Casa da Moeda, 2004.

DRONKE, Peter. As cidades simbólicas de Hildegarda de Bingen. In: CENTENO, Y. A simbólica do espaço: cidades, ilhas, jardins. Lisboa: Estampa, 1991.

ECO, Umberto. A história da beleza. Tradução de Eliana Aguilar. Rio de Janeiro: Record, 2007.

ECO, Umberto. A história da Feiúra. Tradução de Eliana Aguilar. Rio de Janeiro: Record, 2007.

ELIOT. T. S. Ensaios. Rio de Janeiro: Art Editora, 1989.

FERRA, Margarida. A fada madrinha. Jornal de letras, artes e idéias, Lisboa, nำ709, p.10, dez.1997.

FERREIRA, Agripina Encarnación Alvarez. Dicionário de imagens, símbolos, mitos, termos e conceitos bachelardianos. Londrina: Eduel, 2008.

FOUCAULT, Michel. O que é um autor? Tradução de Antônio Fernando Cascais e Eduardo Cordeiro. 4 ed. Lisboa: Vega Passagens.

GOMES, Francisco Casado. O elemento mar na obra de Antônio Nobre. Porto Alegre: Of. Graf. da Livraria do Globo, 1958.

GUATTARI, F.; DELEUZE, G. Mil platôs. Tradução de Peter Pál Pelbart e Janice Caiafa. São Paulo: Editora 34, 1997. v.5: Capitalismo e Esquizofrenia.

GUIMARÃES, Fernando. Simbolismo, modernismo e vanguardas. Lisboa: Imprensa Nacional - Casa da Moeda, 2004.

HEIDEGGER, Martin. Heráclito. A origem do pensamento ocidental: lógica. A doutrina hereclítica do lógos. Tradução de Maria Sá Cavalcante Schuback; preparação Ari Roitman. Rio de Janeiro: Relume Dumará, 1998.

HEIDEGGER, Martin. Interpretaciones sobre la poesía de Hölderlin. Tradução de José Maria Valverde. Barcelona: Editorial Ariel, 1983.

HERACLITO. Fragmentos; traducción del griego, exposición y comentarios de Luis Farre. Buenos Aires: Aguilar, 1963. 
HERCULANO, Alexandre. A Arrábida. Domínio Público. Disponível em: http://www.dominiopublico.gov.br/download/texto/bi000011.pdf. Acesso em: 16 nov. 2010.

HOLANDA, Aurélio Buarque de. Aurélio - dicionário da língua portuguesa. Rio de Janeiro: Nova Fronteira, 2000.

JAKOBSON, Roman. Poética em ação; seleção, prefácio e organização de João Alexandre Barbosa; traduções diversas. São Paulo: Perspectiva: Editora da Universidade de São Paulo, 1990.

LOPES, Óscar. História da literatura portuguesa: As correntes contemporâneas. Lisboa: Alfa, 2002. v.7.

LOPES, Silvina Rodrigues. Exercícios de aproximação. Lisboa: Vendaval, 2003.

LOUREIRO, La Salette. A Cidade em autores do primeiro modernismo Pessoa, Almada e Sá-Carneiro. Lisboa: Editorial Estampa, 1996.

LOURENÇO, Eduardo. Mitología da Saudade. São Paulo: Companhia das Letras, 1999.

MARINHO, Maria de Fátima. A poesia portuguesa nos meados do século XX. Lisboa: Editorial Caminho, 1989.

MARTELO, Rosa Maria. Sophia e o fio de sílabas. In: Estudos em homenagem a Sophia de Mello Breyner Andresen. Porto, p.57-67, 2005.

MOISÉS, Massaud, A literatura portuguesa. São Paulo: Cultrix, 1965.

MOISÉS, Massaud. A literatura portuguesa em perspectiva. São Paulo: Atlas, 1994.

NAVA, Luís Miguel. Ensaios reunidos. Lisboa: Assírio \& Alvin, 2004.

NIETZSCHE, Friedrich Wilhelm. 0 nascimento da tragéia ou helenismo e pessimismo. Tradução, notas e posfácio de J. Guinsburg. São Paulo: Companhia das Letras, 1992.

NOBRE, António. Só. Porto: Livraria Tavares Martins, 1962.

PAES, Sidónio. Harmonia Perfeita. Jornal de letras, artes e idéias, Lisboa, n.749, p8, jun.1999. 
PASSOS, Maria Armanda. Sophia, Prêmio Camões. Jornal de letras, artes e idéias, Lisboa, n.749, jun.1999, p5-6.

PAZ, Octavio. El arco y la lira. Ciudad de México: FCE, 2005.

O arco e a lira. Rio de Janeiro: Nova Fronteira, 1982.

. Os filhos do barro. Rio de Janeiro: Nova Fronteira, 1984.

PEREIRA, M. S. O testemunho poético de Sophia. Jornal de letras, artes e idéias, Lisboa, n505, p.6, mar.1992.

PESSOA, Fernando. Mensagem. São Paulo: Martin Claret, 2003.

Livro do Desassossego. São Paulo: Companhia das

Letras, 2003.

Companhia de Bolso, 2007.

Poesia Completa de Álvaro de Campos. São Paulo:

POUND, Erza. ABC da literatura. Tradução de Augusto de Campos e José Paulo Paes. São Paulo: Cultrix, 1970.

ROCHA, Clara. Sophia de Mello Breyner Andresen: Poesia e Magia. Colóquio / Letras, Lisboa, n. 132-133, p.166-181, Abr.- Set. 1994.

ROSA, António Ramos. O grito puro de Sophia. Jornal de letras, artes e idéias, Lisboa, no 468, p.12-13, jun.1991.

SCHOPENHAUER, Arthur. O mundo como vontade e representação. Rio de Janeiro:Contraponto, Rio de Janeiro, 2001.

SENA, Jorge de. Alguns poetas de 1958. Colóquio / Letras - revista de artes e letras, Lisboa, n. 1, p.53-54, Jan.1959.

SILVEIRA, Jorge Fernandes et al. Escrever a casa portuguesa. Belo Horizonte: Ed. UFMG, 1999.

STEINBERG, Vivian. No poema: um paradigma da tessitura poética de Sophia de Mello Breyner Andresen. Dissertação (Mestrado em Literatura Portuguesa) - Faculdade de Filosofia, Letras e Ciências Humanas, Universidade de São Paulo, São Paulo, 2006. 
STILWELL, Peter. "Uma atenção voltada para fora". Jornal de letras, artes e idéias, Lisboa, no 709, p.6-8, dez.1997.

TAVARES, Francisco Sousa de. "Posfácio", In Antologia mar. Lisboa: Caminho, 2001.

VALÉRY, Paul. Poesia e Pensamento Abstrato. In: Variedades. São Paulo: lluminuras, 1991.

VASCONCELOS, J. C. de. Sophia. Jornal de letras, artes e idéias, Lisboa, n.881, 1982, p.3.

Sophia, a luz dos versos. Jornal de letras, artes e idéias, Lisboa, ํo 468, p. 8, jun.1991.

VERDE, Cesário.O livro de Cesário Verde. Lisboa: Editorial Minerva, 1976. 